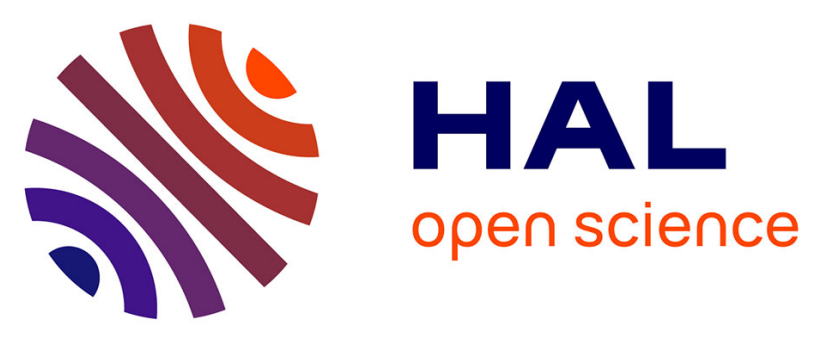

\title{
Guelb el Ahmar (Bathonian, Anoual Syncline, eastern Morocco): First continental flora and fauna including mammals from the Middle Jurassic of Africa
}

Hamid Haddoumi, Ronan Allain, Saïd Meslouh, Grégoire Metais, Michel Monbaron, Denise Pons, Jean-Claude Rage, Romain Vullo, Samir Zouhri, Emmanuel Gheerbrant

\section{To cite this version:}

Hamid Haddoumi, Ronan Allain, Saïd Meslouh, Grégoire Metais, Michel Monbaron, et al.. Guelb el Ahmar (Bathonian, Anoual Syncline, eastern Morocco): First continental flora and fauna including mammals from the Middle Jurassic of Africa. Gondwana Research, 2016, 29 (1), pp.290-319. 10.1016/j.gr.2014.12.004 . insu-01163723

\section{HAL Id: insu-01163723 \\ https://hal-insu.archives-ouvertes.fr/insu-01163723}

Submitted on 16 Jun 2015

HAL is a multi-disciplinary open access archive for the deposit and dissemination of scientific research documents, whether they are published or not. The documents may come from teaching and research institutions in France or abroad, or from public or private research centers.
L'archive ouverte pluridisciplinaire HAL, est destinée au dépôt et à la diffusion de documents scientifiques de niveau recherche, publiés ou non, émanant des établissements d'enseignement et de recherche français ou étrangers, des laboratoires publics ou privés. 


\section{Guelb el Ahmar (Bathonian, Anoual Syncline, eastern Morocco): First continental flora and fauna including mammals from the Middle Jurassic of Africa}

Hamid HADDOUMI ${ }^{a}$, Ronan ALLAIN ${ }^{b}$, Said MESLOUH ${ }^{c}$, Grégoire METAIS ${ }^{b}$, Michel MONBARON ${ }^{d}$, Denise PONS ${ }^{b}$, Jean-Claude RAGE ${ }^{b}$, Romain VULLO ${ }^{e}$, Samir ZOUHRI ${ }^{f}$ and Emmanuel GHEERBRANT ${ }^{\text {b* }}$

* Corresponding author. E-mail address: gheerbra@mnhn.fr (E. Gheerbrant). Tel.: 3314079 30 20. Fax: 33140793080

${ }^{a}$ Département de Géologie, Faculté des Sciences, Université Mohammed 1er, BP. 524, 60 000 Oujda, Maroc. Email: haddoumihamid@yahoo.fr

${ }^{\mathrm{b}}$ CR2P - Centre de Recherches sur la Paléobiodiversité et les Paléoenvironnements, UMR 7207, Muséum National d'Histoire Naturelle, CNRS, UPMC, Sorbonne Universités. MNHN, CP38, 8 rue Buffon, 75005 Paris, France. Email: RA: rallain@mnhn.fr; GM: metais@mnhn.fr; DP: denise.pons@snv.jussieu.fr; JCR: jcrage@mnhn.fr; EG: gheerbra@mnhn.fr

'Ministère de l'Energie, des Mines, de l'Eau et de l'Environnement, Rabat, Maroc. Email: meslouh.said@gmail.com

d Département de Géosciences, Université de Fribourg, Suisse. Email: michel.monbaron@unifr.ch.

'UMR-CNRS 6118, Géosciences Rennes, Université de Rennes 1, Campus de Beaulieu, 263 avenue du Général Leclerc, 35042 Rennes, France. Email: romain.vullo@univrennes1.fr

f Laboratoire de Géosciences, Faculté des Sciences Aïn Chock, Université Hassan II de Casablanca, Km 8, route de l'Université, 20100 Casablanca, Maroc. Email: s.zouhri@fsac.ac.ma 


\section{Abstract}

We report the discovery in Mesozoic continental "red beds" of Anoual Syncline, Morocco, of the new Guelb el Ahmar (GEA) fossiliferous sites in the Bathonian Anoual Formation. They produced one of the richest continental biotic assemblages from the Jurassic of Gondwana, including plants, invertebrates and vertebrates. Both the sedimentological facies and the biotic assemblage indicate a lacustrine depositional environment. The flora is represented by tree trunks (three families), pollen (13 species, five major clades) and charophytes. It suggests local forests and humid (non-arid) conditions. The vertebrate fauna is dominated by microvertebrates recovered by screening-washing. It is rich and diverse, with at least 29 species of all major groups (osteichthyans, lissamphibians, chelonians, diapsids, mammals), except chondrichthyans. It includes the first mammals discovered in the Middle Jurassic of Arabo-Africa. The GEA sites yielded some of the earliest known representatives of osteoglossiform fishes, albanerpetontid and caudate amphibians, squamates (scincomorphans, anguimorphan), cladotherian mammals, and likely choristoderes. The choristoderes, if confirmed, are the first found in Gondwana, the albanerpetontid and caudatan amphibians are among the very few known in Gondwana, and the anguimorph lizard is the first known from the Mesozoic of Gondwana. Mammals (Amphitheriida, cf. Dryolestida) remain poorly known, but are the earliest cladotherians known in Gondwana. The GEA biotic assemblage is characterized by the presence of Pangean and Laurasian (especially European) taxa, and quasi absence of Gondwanan taxa. The paleobiogeographical analysis suggests either a major fossil bias in Gondwana during the Middle Jurassic, and an overall vicariant Pangean context for the GEA assemblage, or alternatively, noticeable Laurasian (European) affinities and North-South dispersals. The close resemblance between the Bathonian faunas of GEA and Britain is remarkable, even in a Pangean context. The similarity between the local Anoual Syncline Guelb el Ahmar and Ksar Metlili faunas raises questions on the ?Berriasian age of the latter.

\section{Research Highlights}

- First discovered Middle Jurassic flora and fauna with microvertebrates from Africa.

- It yields the first Middle Jurassic mammals from Africa (stem Cladotheria).

- The fauna has either Laurasian or Pangean affinities.

Key words: Anoual; Morocco; Middle Jurassic; vertebrates; mammals; flora; Africa.

\section{Introduction}

On the main part of the Moroccan Atlasic domain, continental red beds were deposited since the Middle Jurassic to the Upper Cretaceous (du Dresnay, 1956; Choubert and Faure-Muret, 1960-62; Jenny et al., 1981; Michard et al., 2008). Their age has been highly debated because of the lack of undisputable chronostratigraphic markers. The historical controversy is synthesized in Monbaron 
(1988). Since the 1980s, new paleontological discoveries with significant stratigraphical implications were made, especially for vertebrates (Monbaron and Taquet, 1981; Sigogneau-Russell et al., 1988, 1990; Monbaron et al., 1999; Allain et al., 2004; Haddoumi et al., 2008, 2010) and microfossils (Charrière, 1992; Charrière et al., 1994, 2005). Together with sedimentology study, they also provide new paleoenvironmental and paleogeographical data.

During the geological study of the Anoual Area, eastern part of High Atlas Mountains, Morocco, Haddoumi (1998) and Haddoumi et al. (2008) reported in the Guelb el Ahmar site the discovery of fossil remains of the semionotid fish Lepidotes from a lacustrine limestone bed of the Jurassic Anoual Formation. The fossiliferous bed is located stratigraphically high in the Anoual Formation, about 100 $\mathrm{m}$ below the contact with the Ksar Metlili Formation (Discordance D1 in Haddoumi et al., 2008).

In 2010 we developed new prospects and field researches for vertebrates in the Jurassic and Cretaceous of the Anoual area (Anoual and Qsar Jilali synclines), with the sponsorship of the National Geographic Society. This resulted in the discovery and study of the new Guelb el Ahmar microvertebrate fauna (acronym GEA) from the Anoual Formation that includes in particular the first known Middle Jurassic mammals from Arabo-Africa.

\section{Material and methods}

Most of the recovered fossils are microremains of vertebrates that were collected by water screening- washing (diameter of mesh $=0.8 \mathrm{~mm}$ ), except for larger fossils found by surface collecting. The fossil specimens that were found are deposited in the collections of the University Hassan II Casablanca.

SEM images were made at the UMR 7207 and at the MNHN "Plate-forme de microscopie électronique". Two specimens (GEA 2-1, GEA 2-20) were studied by computed scanning microtomography. CT scanning was conducted at the X-ray Tomography Imagery Platform AST-RX of the MNHN, using a GE Sensing and Inspection Technologies phoenix |x-ray v|tome |x L240-180 CT scanner with the nanofocus RX source $(180 \mathrm{kV} / 15 \mathrm{~W})$. The GEA2-1 scan was made with an isotropic voxel size of $1.35987 \mu \mathrm{m}$ under a voltage of $55 \mathrm{kV}$ and a current of $260 \mu \mathrm{A}$. The GEA2-2 scan was made with an isotropic voxel size of $2.24292 \mu \mathrm{m}$ under a voltage of $90 \mathrm{kV}$ and a current of $170 \mu \mathrm{A}$. Data were reconstructed using phoenix datos $\mid \times 2.0$ reconstruction. 3D processing and modelling of the CT scans were made with the help of the program Materialise Mimics Innovation Suite 16 at the 3D imaging platform of the UMR 7207 (CR2P).

Paleobotanic studies. Palynological samples were processed using the standard treatment used in palynology (Erdtman, 1943; Batten, 1999). The slides were analysed under a Nikon Eclipse 80i light microscope using a differential interference contrast objective (after Nomarski) and equipped with a Nikon D 300 digital camera. Several separate optical section pictures were taken for each sample and photographic depth of field was reconstructed using the program Helicon Focus.

\section{Abbreviations}

GEA: Guelb El Ahmar locality (3 loci, GEA I, 2, 3; Anoual Syncline), belonging to the Anoual Formation, Bathonian. 
KM: Ksar Metlili locality (Anoual Syncline), belonging to the Ksar Metlili Formation, ?Berriasian.

\section{Location and geological context}

\subsection{Geological and stratigraphical context}

The Guelb el Ahmar sites (acronym GEA) yielding vertebrate remains are located on the northern rim of the eastern High Atlas Mountains, about $7 \mathrm{~km}$ NNE of Anoual city (Fig. 1). The mostly continental Jurassic red beds ["couches rouges" also termed Continental Intercalaire by pioneering French geologists (e.g., Kilian, 1931)] are widely distributed in the Middle and High Atlas Mountains (Allain and Aquesbi, 2008). Their age has been highly debated because of the lack of undisputable chronostratigraphic markers (du Dresnay, 1969; Monbaron, 1988). In the Atlasic domain, this clastic sequence of red beds corresponds to the filling of Middle Jurassic basins, and it precedes the Aptian or the Cenomanian marine transgression (Choubert and Faure-Muret, 1960-1962; du Dresnay, 1979, Charrière, 1992, 1996). In the Anoual area, this sequence of red beds is stratigraphically sandwiched between the marine upper Bajocian-?lower Bathonian marly calcareous unit (Pholadomya marls and limestones Formation) and the marine Cenomanian-Turonian limestone bank (Fig. 2).

<<Fig. 1 here >>

In the Anoual area, these red beds are moderately affected by tectonics and are about 500 meters thick (Haddoumi et al. 2008, fig. 1). They are usually divided in two or three lithological units separated by disputed unconformities. The considerable time interval of deposition (from the Middle Jurassic to the Early Cretaceous) for these red beds suggests numerous hiatuses (du Dresnay, 1969; Monbaron, 1988). In the Anoual Syncline, Haddoumi et al. (2008) differentiated three lithostratigraphic units of red clastics (Fig. 2), from base to top: the Anoual Formation (lower Bathonian), the Ksar Metlili Formation (?Berriasian or late Tithonian-early Berriasian transition), and the Dekkar Group (?Barremian to Cenomanian). The Ksar Metlili Formation ( $\sim 80 \mathrm{~m}$ thick) is delimited by two unconformities (Haddoumi et al., 2008, fig. 2). It has yielded the Ksar Metlili microvertebrate fauna (Sigogneau-Russell et al. 1988, 1990; also called "Anoual fauna" in Sigogneau-Russell et al., 1998), that includes the most diversified African and Gondwanan Mesozoic mammal assemblage. The Ksar Metlili Formation is dated as Berriasian on the basis of calcareous nannofossils (coccolithophores) found in a marly bed located below the microvertebrate lens (Sigogneau-Russell et al., 1990), or late Tithonian-early Berriasian based on charophytes found in a bed located 5-7 meters above the microvertebrate lens (Haddoumi et al., 2008; Mojon et al., 2009; see fig. 2). The Berriasian age of the nannofossils found in the Ksar Metlili Fm needs to be further tested with additional biostratigraphic data.

<<Fig. 2 here>>

The Guelb el Ahmar fauna is stratigraphically located in the upper part of the Anoual Formation, which is about 500 meters thick. The Anoual Formation is subdivided into a thick continental lower member, and a shallow marine carbonaceous upper member delimited at the top by the erosional unconformity D1 that marks the contact between the Anoual and Ksar Metlili formations (Haddoumi et al. 2008). The Bathonian age of this upper marine member (Fig. 3) is constrained by the brachiopod fauna (Haddoumi et al. 1998). 
<<Fig. 3 here >>

The lithology and sedimentary structures of the lower member suggest a flooding plain and/or deltaic depositional environment. This is consistent with the large fossil trunks that are common in that unit. The fossiliferous levels yielding the Guelb el Ahmar (GEA) vertebrate fauna belong to the upper part of the lower member of the Anoual Fm (Fig. 2). Two contiguous fossiliferous beds yielding microvertebrates have been sampled at Guelb el Ahmar (Fig. 4). The lower fossiliferous level is a lacustrine limestone yielding small and medium-sized fossil remains, including fishes and turtles (see Table 1). The top of this lacustrine bed is capped by a duricrust yielding abundant remains of fishes such as Lepidotes; it was sampled especially at GEA 1 and GEA 3 sites. This crust of a few centimeters (its thickness varies laterally) is overlaid by a thin bed of dark-brown, slightly lignitic marls that were intensively sampled (GEA 2) for screen-washing (see below). They are covered by 2-3 meters of green-greyish marls which pass upward into reddish mudstone and cross-bedding sandstone with bioturbation, and other sedimentary structures suggesting a fluviatile-deltaic depositional environment.

<<Fig. 4 here >>

$<<$ Fig. 5 here $>>$

3.2 The Guelb el Ahmar microvertebrate faunas and sites (Anoual Fm, Bathonian)

Three Bathonian sites in the Guelb el Ahmar area, from the Anoual Fm (lower member), were sampled for research and study of its (micro) vertebrate fauna during our field work in 2010.

GEA 1: North $32^{\circ} 44^{\prime} 00^{\prime \prime} ;$; West $03^{\circ} 08^{\prime} 40^{\prime \prime}$. This site corresponds to lacustrine limestones rich in semionotiform fishes remains, mostly represented by "Lepidotes" scales. $650 \mathrm{~kg}$ of lacustrine limestone were sampled in GEA 1 site and are still being chemically processed by acid-attack to extract additional vertebrate remains (they are not included, nor discussed in the present paper).

GEA 2: North $32^{\circ} 43^{\prime} 43.00^{\prime \prime}$; West $03^{\circ} 09^{\prime} 06.00^{\prime \prime}$. This is a new site that was sampled during our 2010 fieldwork in a level of brownish (to variegated) and gypsiferous marls overlying the lacustrine limestones rich in fishes. It is located $1 \mathrm{~km} \mathrm{SSW}$ from GEA 1. The microfauna reported here from this site was recovered following sampling and screening-washing of $1200 \mathrm{~kg}$ of sediment (Fig. 5). The screening residue that was sorted for recovery of fossil vertebrate microremains represented about $50 \mathrm{~kg}$, i.e., $4 \%$ of the sampled sediment.

GEA 3: North $32^{\circ} 43^{\prime} 42.00^{\prime \prime}$; West $03^{\circ} 09^{\prime} 07.00^{\prime \prime}$. This is a new site close to GEA 2 that was sampled at the top of the lacustrine limestones rich in fishes for recovery of vertebrate mesoremains, mostly of crocodilians, by surface collecting. Additionally to crocodilians, it yielded lungfishes and chelonians.

GEA 3 and GEA 1 correspond to the same level of calcareous lacustrine limestones, which underlies GEA 2.

<<Fig. 6 here>> 


\section{Paleobotanical analysis of Anoual Formation samples (Fig. 6, 8A)}

A research for spores and pollen was developed in several levels from Anoual and Ksar Metlili Fms. In this aim, we sampled and studied nine localities of the Anoual Formation including the GEA 1 lacustrine limestones, the GEA 2 brownish marls, and a level of lignite from the base of the formation. Only two of them yielded results.

Wood remains were also identified from one level called Oued Metlili lignites of the Anoual Fm They are also represented by abundant large fragments of trunks in the Anoual Formation.

\section{Brown marls GEA 2 (Fig. 6 A-H)}

The organic matter is present, but very altered and translucid. Besides some Quaternary polluting, only pollen and spore grains were recognized:

- Green algae: Botryococcus sp., Schizosporis sp.;

- Ferns: Cyathidites sp., Ischyosporites variegatus (Couper) Schulz 1961, Leptolepidites sp.;

- Pteridospermales: Alisporites sp.;

- Cycadales/Bennettitales: Cycadopites sp.;

- Conifers: Araucariacites australis Cookson 1947 ex Couper 1953, Callialasporites sp., Classopollis sp., Inaperturopollenites sp., Pityosporites sp., Bisaccates spp.

The presence of pollen of Cheirolepidiaceae (Classopollis) and Araucariaceae (Araucariacites australis) agrees with the occurrence in the Anoual Fm of abundant fossil wood trunks of conifers (Fig. 7). Dinoflagellate cysts and marine microfossils are absent in GEA 2. Unfortunately, the palynoflora identified in GEA 2 does not include any accurate stratigraphical diagnostic taxon. Araucariacites australis and Classopollis are known from the Upper Triassic (Rhaetian) to the Cretaceous. Ischyosporites variegatus (Schizaeaceae hygrophile) appears in the Hettangian and the first Callaliasporites in the Toarcian. The palynoflora recovered in GEA 2 indicates an age no older than Toarcian and suggests deposition within lacustrine in a freshwater environment (Van Erve, 1977; Fenton, 1984; Hoelstad, 1985; Thusu and Vigran, 1985; Guy-Ohlson, 1986; Schweitzer et al., 1987; Thusu et al., 1988; Bucefalo Palliani, 1997; Barron et al., 2010; Dehbozorgi et al., 2013).

Besides pollen and spore grains, the brown marls of GEA 2 site also yielded a microflora of poorly preserved and undetermined oogones of Charophyta during the sorting of the fossil remains (Fig. 8A). The charophytes from the lacustrine limestones of Guelb el Ahmar were previously studied by Mojon in Haddoumi et al. (2008) and Mojon et al. (2009), who identified the species Aclistochara africana (Characeae) of Pangean affinities.

\section{Oued Metlili lignites (Fig. 6 I-N)}

Our sample in this lignitic level located at the base of the Anoual Fm has yielded pycnoxylic homoxyleous wood remains, characterized by uniseriate rays with thin and smooth walls, and numerous radial pits of different types: uniseriate flattened, contiguous or rarely spaced pits. Some sectors have araucarian and biseriate pits or biseriate rounded to squared opposite pits. In radial section, cross-fields appear to contain 4-6 (8) alternately arranged inclined pits per field. 
This wood is close to Protopodocarpoxylon subrochii Attims 1965, a conifer with mixed structural tendency. This species was discovered close to the Boulemane to Missour road, south of the "col des quatre vents" (see du Dresnay, 1969, fig. 4), in the Aït-Kermousse syncline. According to du Dresnay (1969), both the age and locality of the holotype of $P$. subrochii are uncertain.

The structure of the Anoual wood also closely resembles that of a fossil wood trunk with branches studied by Boureau $(1951,1957)$ from the Anoual Syncline, and dated as Middle Jurassic by du Dresnay (1969). It was identified as related to the species Protopodocarpoxylon teixeirae Boureau 1949 from the Early Cretaceous of Portugal. However, the Morrocan fossils represent a distinct species. Both Moroccan and Portuguese species should probably be transferred to the genus Brachyoxylon (Cheirolepidiaceae).

The wood structure of material from Oued Metlili lignites also closely resembles that of Protopodocarpoxylon teixeirae and Protocupressinoxylon chouberti, studied by Attims (1965), from the Middle Jurassic (du Dresnay, 1956) of the Skoura Syncline. These two specimens should be revised and referred to the Cheirolepidiaceae family. 
Conclusion on the flora from the Anoual Fm

The occurrence of large fossil tree trunks (diameter $>50 \mathrm{~cm}$, up to $80 \mathrm{~cm}$ ) in the Middle Jurassic of the Atlas continental deposits (Choubert and Diouri, 1969; du Dresnay, 1969; Haddoumi, 1998; and our field observations), such as the Anoual Formation (various sites, e.g. Fig. 7), indicates the presence of local forests. However, the taxonomic diversity of local woods was low and restricted to three families: Araucariaceae [Dadoxylon (Araucarioxylon) aff. sahariense Veillet-Bartoszewska in Gazeau 1969], Cheirolepidiaceae (Protopodocarpoxylon teixeirae Boureau 1949, Protocupressinoxylon chouberti Attims 1965), and Podocarpaceae (Protopodocarpoxylon pro parte, Phyllocladoxylon atlasicum Crémier 1969 and Metapodocarpoxylon libanoticum (Edward 1929) Dupéron-Laudoueneix and Pons, 1985). A low wood diversity in northern Gondwana was already mentioned by Pons (1988) and Philippe et al. (2004). The absence or very weak growth rings in these woods from the Jurassic of Anoual indicates a continuous cambium activity under stable climatic conditions. The wood association from the Jurassic of Anoual also supports an even although low level of moisture.

\section{Systematic Palaeontology of the Guelb el Ahmar fauna}

Most of the fossil material from Guelb el Ahmar consists of fish scales and isolated crocodilian teeth. The brown marl level sampled in locality GEA 2 yielded only fragmentary remains and most of the microvertebrate assemblage described here; fragments of turtle plates are the largest fossils found in this level. The underlying lacustrine limestone yielded medium-size specimens, including scattered elements of the same crocodilian individual at GEA 3 site.

One remarkable feature of the microfauna from Guelb el Ahmar is the absence of any tooth of selachians, in contrast to the ?Berriasian microfauna of Ksar Metlili (e.g., Duffin and Sigogneau Russell 1993) in the same Anoual syncline and to other Jurassic localities from Africa (for a review, see López-Arbarello et al., 2008).

<<Fig. 8 here >>

\section{Arthropoda von Siebold, 1848}

Some poorly preserved shells of ostracods were recovered from the GEA 2 site (Fig. 8B). According to Haddoumi et al. (2008) and Mojon et al. (2009), the ostracods from the Anoual Fm belong to marine (two species) and laguno-lacustrine (nine species) forms.

\section{Mollusca Linnaeus 1758}

Numerous small shells of gastropods were found at GEA 2. Planorbids (Fig. 8C) show a planispiral shell, while lymnaeids (Fig. 8D) and valvatids (Fig. 8E) have a high and low helicoidal shell, respectively. This association is typical of freshwater environments and commonly occurs in Jurassic continental assemblages (e.g., Yen and Reeside, 1952).

\section{Vertebrata Lamarck 1801}

Pisces Linnaeus, 1758 
Osteichthyes Huxley, 1880

Actinopterygii Klein, 1885

Lepisosteiformes Hay, 1929

Lepidotes sp. or Scheenstia sp. (Fig. 9A, 10A)

Material: isolated teeth and scales

Small subconical teeth, devoid of carinae and ornamentation, have been found at GEA 2 (Fig. 9A). Rather large ganoid scales are common in the limestone of GEA 1 and GEA 3 (Fig. 10A). These scales are rhomboid and thick, and the enamelled outer surface is smooth. Similar scales from the Middle Jurassic of the Democratic Republic of the Congo (Leriche, 1911, 1920; Hussakof, 1917) have been described as Lepidotus (= Lepidotes) congolensis (nomen dubium). In Morocco, Lapparent (1955) described some scales of a large form referred to Lepidotes sp. from the Bathonian of El-Mers. The material here described can be referred either to the genus Lepidotes s.s. or to the genus Scheenstia, the valid species of which being Early and Late Jurassic-Early Cretaceous in age, respectively (López-Arbarello, 2012).

cf. Ionoscopiformes Grande and Bemis, 1998

cf. Ionoscopiformes indet. (Fig. 9B)

Small ganoid scales are one of the most abundant elements in the marls of GEA 2. Most of these scales are thin and show a rhombic shape. The outer enamelled surface is smooth and the posterior margin bears fine indentations. Such scales are present in ionoscopiform fishes and can be tentatively assigned to ophiopsids, a widespread family already known in the Middle Jurassic of Africa (Democratic Republic of the Congo) (Saint-Seine and Casier, 1962; López-Arbarello et al., 2008).

$<<$ Fig. 9 here >>

Osteoglossiformes Berg, 1940 (Fig. 9C-D)

Abundant small squamules, rectangular or polygonal in shape, have an ornamentation consisting of small granules bent in the same direction (Fig. 9E). They cannot be distinguished from osteoglossiform squamules described from various Cretaceous and Paleogene non-marine deposits (Gayet and Meunier, 1983; Prasad, 1987; Gayet and Brito, 1989; Werner, 1994; Taverne et al., 2007) and are therefore referred to this group. Interestingly, similar squamules were also described from a microvertebrate site (Mile 175 locality) in the Late Jurassic Morrison Formation of Wyoming (Foster and Heckert, 2011: fig. 4), but these specimens were identified as scales of Actinopterygii indet. As previously noted by Sigogneau-Russell et al. (1990: 470), squamules of osteoglossiforms are also present in the Ksar Metlili locality (Ksar Metlili Fm), but they have never been described or figured. This material includes granulated squamules (Fig. 9F) which are very similar to those from the GEA locality. The osteoglossiform remains of the Middle Jurassic of Anoual Syncline represent the earliest known occurrence of this teleostean order. It is worth noting that a molecular phylogenetic analysis performed by Kumazawa and Nishida (2000) suggested a late Paleozoic origin of the order Osteoglossiformes. The GEA Bathonian fauna thus reduces the time gap between molecular and 
fossil evidences. This early occurrence of osteoglossiforms is also consistent with the recent mean posterior age estimate (Permian, $279.8 \mathrm{Ma}$ ) from the relaxed morphological analyses for the crown teleost lineage, thus implying a strong sampling bias (Friedman et al., 2014).

<<Fig. 10 here>>

Sarcopterygii Romer, 1955

Actinistia Cope, 1870

Mawsoniidae Schultze, 1993

Mawsoniidae indet. (Fig. 10C-E)

Material: skull bones including a parasphenoid (Fig. 10C) from GEA 3.

Description

A few cranial bones show an ornamentation consisting of well-marked, subparallel and sometimes bifid ridges (Fig. 10D-E). This is found for instance in parietals, angulars or operculum of mawsoniid coelacanths (Carvalho and Maisey, 2008). In addition, a triangular parasphenoid tooth plate displaying a rugose surface was collected (Fig. 10C). It is similar to that described in Cavin and Forey (2004: fig. 5b). In Africa, mawsoniids are known from the Middle Jurassic of Lualaba (Democratic Republic of the Congo) with the genus Lualabaea (López-Arbarello et al., 2008).

Dipnoi Müller, 1884

Arganodontidae Martin, 1982

Arganodus Martin, 1979

Arganodus sp. (Fig. 10F-G)

Material: isolated teeth (Fig. 10F-G) from GEA 1-3

Several tooth plates were found in both GEA 2 and 3 stratigraphic levels. They are conspecific but show a wide size range, indicating that several age-classes (i.e., from neonates to adults) are represented here. They show a right triangle outline in occlusal view and bear seven salient, sharp crests radiating from the inner angle. The unworn lingual extremities of the crests can show some small cusps. The mesial (first) crest is slightly curved while other ones are straighter. The lingual (seventh) crest is less developed and partly fused to the sixth one. Due to these morphological features, these tooth plates can be unambiguously assigned to the genus Arganodus [considered by Kemp (1998) as junior synonym of Asiatoceratodus, an opinion not followed by Cavin et al. (2007)] (Martin, 1984). Arganodus is well represented in the Mesozoic rocks of northern Africa, where two species are known: $A$. atlantis from the Triassic of Morocco and Algeria, and A. tiguidiensis from the Late Jurassic-Early Cretaceous of Algeria, Ethiopia and Niger (Martin, 1979, 1984; Goodwin et al., 1999; Soto and Perea, 2010). The latter species mainly differs from the former by its smaller and more elongated tooth plates (Martin, 1984). 


\section{Osteichthyes indet. (Fig. 9C-D)}

Numerous small, indeterminate osteichthyan ichthyoliths are present in the GEA 2 assemblage. Some ornamented specimens are characterized by an outer surface showing fine, blunt, wavy ridges (Fig. 9E) or by bent, irregularly arranged, spiny tubercles (Fig. 9F).

Pisces indet. (Fig. 10B)

An isolated, incomplete spine displaying a single row of well-developed, bent (upturned?) denticles was collected at GEA 3. This spine seems to be partly hollow and its external surface is smooth. It is morphologically reminiscent of cypriniform or siluriform spines commonly found in Cretaceous and younger non-marine deposits (e.g., Gayet and Brito, 1989: pl. 1, fig. 10). In addition, the presence of possible cypriniform remains was mentioned in the Ksar Metlili Fm (SigogneauRussell et al., 1998). However, this specimen cannot be confidently assigned to an ostariophysan fish due to both its fragmentary nature and Bathonian age (although a recent molecular phylogenetic analysis has revealed that the major ostariophysan lineages diversified in the Middle Jurassic; Wang et al., 2011). Alternatively, this specimen could represent a myriacanthid holocephalan spine fragment, as suggested by its median row of large denticles (Duffin, 1981, 1983). Moreoever, a row of upturned denticles can be present in Myriacanthus spines (E. Popov, pers. comm., 2014). However, the lack of tuberculation on the lateral walls and the non-marine origin of this specimen do not allow its definitive assignment to the Myriacanthidae. Therefore, this specimen is referred to an indeterminate fish pending further analysis and discoveries.

\section{Amphibia Linnaeus, 1758}

Lissamphibia Haeckel, 1866

Allocaudata Fox and Naylor, 1982

Albanerpetontidae Fox and Naylor, 1982

Albanerpetontidae indet.

Material: GEA 2-22, an incomplete premaxilla (Fig. 11A); GEA 2-21, an incomplete frontal (Fig. 11B).

Description

An incomplete azygous premaxilla belongs to albanerpetontids. It preserves the ventral part of the pars dorsalis and the median portion of the pars dentalis. Although incompletely preserved, it may be stated that it likely belongs to the 'gracile type' (Gardner, 2002). There is no trace of a sagittal suture. The labial face does not bear ornamentation, i.e. ornamentation did not reach the ventral part of the pars dorsalis. Some circular pits are perhaps nutritive foramina. On the lingual face, the pars palatinum markedly projects posteriorly but its margin is broken away. A sagittal, blunt ridge extends on the lingual face of the pars dorsalis; it separates two depressions. The left depression is filled with matrix, but an elliptical, comparatively large suprapalatal pit opens in the right one. The pit is located against the sagittal ridge and against the pars palatinum; it faces posterolaterally. Only bases of teeth are preserved; teeth were deeply pleurodont, narrow and closely spaced. 
The posterior part of a frontal is available. The bone is azygous as in all albanerpetontids. Its posterior and left borders are damaged. The bone narrows anteriorly. Its dorsal face is flat and it bears an ornamentation that poses a problem. The ornamentation varies with the intensity and angle of the light. Observed under low and low-incident light, the ornamentation consists of some approximately polygonal, irregular cells enclosed by low but rather well-defined ridges; the bottoms of the cells are flat and small, round pits are located there. The cells are larger than those of other albanerpetontid species. However, if observed under strong light or in SEM images, parts of the ridges are no longer visible and cells no longer appear as such (Fig. 11B). On the ventral face, a sagittal low ridge extends through the entire length of the remains. The ventrolateral crests are comparatively broad.

Comments

This albanerpetontid appears to be distinct from all known species. The ornamentation of its frontal is peculiar; in other albanerpetontids, it consists of moderately large and shallow, polygonal to ovaloid depressions or cells. In addition, the combination of the azygous nature of the premaxilla and of the position of the suprapalatal pit close to the pars palatinum is shared only with the North American Albanerpeton nexuosum (Late Cretaceous and ?Albian) and the 'Paskapoo species' (Paleocene) and with the European $A$. inexpectatum (Miocene) and A. pannonicus (Pliocene). However, it differs from the latter four species by the posterolateral orientation of its suprapalatal pits, the orientation being posterior in these four species (Gardner, 2002; Gardner and Böhme, 2008). It differs also from Wesserpeton (from the Barremian of Britain; Sweetman and Gardner, 2013) in having an azygous premaxilla and a sagittal ridge on at least a part of the ventral face of the frontal.

Comparisons with Anoualerpeton are of particular interest. This genus includes two species; An. unicus, from the earliest Cretaceous of Morocco, was recovered from the close locality Ksar Metlili, while An. priscus, found in Britain, is of Bathonian age, as is the form described here. The form from GEA 2 differs from the two species of Anoualerpeton by the pattern of ornamentation of the frontal (see above), but also in having an unpaired premaxilla wich lacks any trace of suture (paired in Anoualerpeton) and suprapalatal pits close to the pars palatinum (dorsally distant in Anoualerpeton) (Gardner, 2002; Venczel and Gardner, 2005). In addition, the frontal is broader than that of An. unicus, the difference in width being weaker in An. priscus.

Finally, it is possible to state that the albanerpetontid from GEA 2 represents a new taxon. Unfortunately, the available material does not permit to name this taxon and no attempt to a phylogenetic analysis can be made. This albanerpetontid is the earliest one along with Anoualerpeton priscus from Britain and an indeterminate form from France (Gardner and Böhme, 2008) and it is one of the only two species (along with An. unicus) of the clade recovered from a Gondwanan area.

<<Fig. 11 here>>

? Caudata Scopoli, 1777

Family indeterminate

Material: GEA 2-29, a fragment of a dentary (Fig.11C). 
Description

The fragment is a short portion of the anterior part of a dentary, from the area that is between the symphysis and the anterior extremity of the Meckelian groove. This preserved portion is thick and robust. The lateral face is convex and, except the pars dentalis, it is ornamented with round, shallow depressions. On the lingual face, the pars dentalis represents approximately one-third of the height of the bone. The bases of three teeth are preserved; they are pleurodont and cylindrical. A broad and dorsally concave subdental shelf is present. Ventral to the subdental shelf, the medial surface of the dentary is flat, without any trace of a groove, and it slopes ventrolaterally.

\section{Comments}

The stout transverse section, shallow pars dentalis (with regard to the height of the bone) and the broad subdental shelf are characteristics occurring in the post-symphyseal region of the dentary of basal salamanders such as Urupia (Bathonian of Western Siberia; Skutchas et al., 2005; Skutchas and Krasnolutskii, 2011) and in cryptobranchoids (?Bathonian to Present; Vasilyan et al., 2013). The compactness of the bone is very high, as is in Urupia, since no cavity appears in the transverse section. In cryptobranchoids, the compactness is high but cancellous bone and cavities lighten the bone. However, the absence of cavities in GEA 2-29 and Urupia may result from fossilization.

Dentaries of two other caudatans from the Bathonian are known. GEA 2-29 differs from Marmorerpeton from the Bathonian of Britain (Evans et al., 1988) in having a clearly shallower pars dentalis and in lacking a horizontal groove on the lateral face of the dentary. In Kokartus from Kyrgyzstan, the Meckelian groove reaches the symphysis (i.e., there is no portion without Meckelian groove) and the lateral face bears an ornamentation comprised of parallel ridges.

It should be noted that peculiar caudatans were reported from the Gondwanan Mesozoic, more specifically from the Cretaceous of Africa and South America. They were regarded either as endemic to Western Gondwana (as Noterpetontidae; Rage et al., 1993) or as members of the sirenids that are primarily known from North America (Evans et al., 1996). In Africa, they are represented by species of the Cenomanian genus Kababisha. The dentary of the latter bears a marked horizontal groove on its lateral face; GEA 2-29 lacks this groove.

The similarity between GEA 2-29, Urupia and cryptobranchoids clearly suggests referral to Caudata, especially as such dentaries appear to be unknown in other vertebrates. However, in view of the very limited nature of the specimen, the referral cannot be made without reservation.

If really a salamander, then GEA 2-29 is one of the earliest representatives of the group, along with a few other Bathonian fossils: Marmorerpeton and two indeterminate salamanders from Britain (Evans et al., 1988; Evans et al., 2006), Urupia and two indeterminate forms from Western Siberia (Skutchas and Krasnolutskii, 2011; Skutchas, 2013) and Kokartus from Kyrgyzstan (Skutchas and Martin, 2011). Moreover, Gao et al. (2013) regarded Chunerpeton, Jeholotriton and Liaoxitriton from China as taxa of Bathonian age; however, the Daohugou beds that produced these fossils are likely post-Bathonian (Sullivan et al., 2014). GEA 2-29 is therefore the earliest salamander from Africa, a continent from which extinct and extant salamanders are extremely rare. 
?Lissamphibia incertae sedis

Material: GEA 2-2, an incomplete maxilla (Fig. 11D and Suppl. Fig. S1).

A puzzling maxilla was recovered from GEA 2. Although referral to fishes (? Amiiformes) cannot be definitely rejected, it is tentatively assigned to lissamphibians on the basis of the morphology of its teeth.

\section{Description}

The specimen (GEA 2-2) is a right maxilla; it is well ossified, strongly built and thick. In lateral or medial view, a curved emargination is interpreted as the posteroventral margin of the orbit. It cannot be the limit of the external naris because it is located at the level of the posterior portion of the tooth row. The bone being very thick, the ventral margin of the orbit forms a rather broad floor. A foramen opens in the posterior part of the orbital margin; the foramen is prolonged anterolaterally by a short groove. The border of the orbit slightly protrudes laterally, thus forming a low rim. The bone markedly extends posterior to the orbit. There is no true ornamentation; however, the lateral surface is pitted in a way that is clearly reminiscent of Gymnophiona (Wilkinson et al., 2011). A semi-circular depression is located posteroventrally to the rim of the orbit on the lateral side. Just dorsal to the tooth row, the ventral part of the lateral wall is separated from the more dorsal area by a break and it rotated medioventrally. Consequently, its ventral border is close to the tooth row. However, before breakage and displacement, a rather broad space separated the tooth row from the lateral wall.

Medially, only the posterior part of the tooth row is preserved. The bases of five teeth are preserved. Teeth are clearly pleurodont and cylindrical. They are all broken at the level of the edge of the crista dentalis and the breaks are clear and horizontal. This suggests that teeth were pedicellate, the surfaces of the tooth sections being likely significant (Greven and Clemen, 1980). It is presumed that teeth were broken through their 'dividing zones' and that the preserved portions are the pedicels. The tooth row ends abruptly, slightly posterior to the orbit. There is no pars palatinum (= lamina horizontalis). Posterior to the orbital emargination is the base of a strong medial process directed posteromedially and slightly ventrally. The process is broken and its section is subcircular. The process is prolonged ventrally and slightly posteriorly by a thick, slightly curved blade whose medial part is broken away. The ventralmost part of the blade covers the posterior end of the tooth row. The medial extents of the process and of the blade cannot be estimated. The process, and perhaps part of the blade, likely contacted the braincase posterior to the foramen for the optic nerve. The ventral part of the blade perhaps articulated with the pterygoid. Anteriorly, the process is prolonged by a horizontal shelf that grades into the ventral margin of the orbit. This shelf cannot be a pars palatinum because it lies distant, dorsal to the teeth. A large chamber is located posteroventrally to the orbit, between the base of the medial process and the lateral wall. The chamber is dorsal to the tooth row and it is clearly separated from the space that is between the tooth row and lateral wall. The chamber opens, on the medial face of the bone, as a large foramen facing posteromedially and that is located posterodorsal to the base of the process. The chamber prolongs, as a broad canal, within the anterior part of the maxilla, ventral to the orbital emargination. Canals originate in the chamber and lead to several foramina. It is not possible to describe all canals. However, one of these foramina opens in the posterior part of the orbital margin (see above). Three foramina open at the base of the process, one posteriorly and two ventrally. One foramen sits in the medioventral border of the horizontal shelf. A foramen likely opens in the space between the tooth row and the lateral wall. On the medial face of the specimen, a short curved line posterior to the process and to the large 
opening of the chamber may represent a suture between the maxilla and another bone. If that is the case, the entire outline of the suture is unknown and it does not appear on the lateral face of the bone.

\section{Comments}

This singular maxilla is tentatively assigned to Lissamphibia on the basis of the inferred pedicellate nature of its teeth. Aside from thickness and strong ossification, one of the most striking features of this bone is the extent of the lateral wall posterior to the orbit. In this respect, it may be entertained whether the emargination really corresponds to the orbit and not to the external naris. In the latter case, the posterior extension would be the dorsal (also termed prefrontal) process of the maxilla itself that forms the posterior margin of the naris and is anterior to the orbit in amphibians. However, the position of the emargination, only slightly anterior to the posterior end of the tooth row, leads to discard this possibility.

Assuming that the emargination corresponds to the orbit, the posterior extent of the bone may be formed by the maxilla itself or by fused postorbital bones. The fact that the tooth row terminates markedly anterior to the posterior part of the bone clearly suggests that at least one element is fused to the maxilla. On the medial face, a line may be regarded as the trace of a suture (see above). In Gymnophiona, the orbit (where present) is limited posteriorly by bone(s) whose homology may be discussed (Carroll and Currie, 1975; Trueb, 1993; Wilkinson et al., 2011). Generally, in Caudata and Anura, the orbit is not limited by bone posteriorly. However, in some strongly ossified taxa, the squamosal can form a more or less complete posterior border and may fuse to the maxilla. Only Allocaudata always lack a posterior bony margin. However, whatever the nature of the bone posterior to the orbit, GEA 2-2 markedly differs from these taxa (Gymnophiona, Caudata, Anura, Allocauduta) by the thickness of the bone which forms a very broad ventral margin of the orbit, the absence of a pars palatinum, the presence of a chamber posteroventral to the orbit, and in having a marked space between the tooth row and lateral wall. GEA 2-2 further differs from Gymnophiona in lacking either an extensive contact or fusion with the palatine; in gymnophionans, the palatine bears a row of teeth that is medial to that of the maxilla, a condition that is already present in the earliest gymnophionan, Eocaecilia from the Early Jurassic (Jenkins et al., 2007).

Two features deserve special attention: the chamber that is located posteroventrally to the orbit and the space that lies between the tooth row and the external wall. The chamber is enigmatic. If the emargination were part of the external naris, then the chamber might be interpreted as the accommodation for the tentacular apparatus, as is known in gymnophionans. However, there is apparently no canal exiting outwards. Anyway, since the emargination quite likely corresponds to the orbit, the chamber cannot be identified. The function of this chamber and what was housed in it remain unknown. The space that is lateral to the tooth row is also a very peculiar feature. It is unmatched in amphibians and its role, if any, cannot be explained.

Finally, GEA 2-2 is characterized by a unique combination of characters: teeth pleurodont and likely pedicellate, bone very thick, teeth and lateral wall separated by a space and presence of a chamber located in the bone posterior to the orbit. It is tentatively referred to as Lissamphibia incertae sedis. However, the strong build and posterior extent of the lateral face more or less suggests that it might belong to the stem of lissamphibians, if really related to this group. 
At least four different morphotypes based on shell ornamentation and plate size, most likely representing four different taxa, have been recognized at GEA 2 and GEA 3 sites. However, all turtle specimens are identified here as Testudinata indet. due to the fragmentary nature of the material. In Morocco, turtle remains were reported from the Bathonian of El Mers (Termier et al., 1940), but this material has never been described in detail nor figured and thus cannot be compared to the specimens found at GEA.

<<Fig. 12 here>>

Testudinata indet. 1 (Fig. 12A)

This morphotype is represented by about fifty plate fragments. The external surface of all these elements is ornamented with blunt, irregular and clearly defined vermiculations. One of the specimens is a fragment of costal plate (Fig. 12A). This type of ornamentation is similar to that observed in Late Jurassic-Early Cretaceous solemydid and pleurosternid cryptodiran turtles (Milner, 2004; Pérez-García et al., 2013). The only other Middle Jurassic turtles to have a vermiculate ornamentation are Heckerochelys from western Russia (Sukhanov, 2006) and Siamochelys from Thailand (Tong et al., 2002). However, this ornamentation seems to be less pronounced in those taxa than in the Moroccan specimen.

Testudinata indet. 2 (Fig. 12B)

The second morphotype is represented at least by a neural plate slightly longer than wide. It is devoid of any ornamentation and characterized by its small size and a median longitudinal carina displaying a well-defined anteroposteriorly elongated groove (Fig. 12B).

Testudinata indet. 3 (Fig. 12C-D)

The third morphotype is also represented by smooth plates (Fig. 12C) and is by far the most abundant. The peripheral plates are nevertheless ventrally ornamented by longitudinal costulations (Fig. 12D). It may correspond to a larger form.

Testudinata indet. 4 (Fig. 12E)

The last morphotype is known by two small incomplete costal plates (Fig. 12E), the ribs of which are clearly visible on their ventral surface. The crocodile osteoderm-like ornamentation of the plates consists of clearly defined and closely spaced, deep alveoli. It is similar to the pitted ornamentation observed in the Early Cretaceous genus Araripemys and some mid-Cretaceous trionychids (Vitek and Danilov, 2014: fig. 3f). In the Mesozoic of Africa, such pit-decorated plates have been reported in araripemydids from various Early Cretaceous localities (Fuente and Lapparent de Broin, 1997).

The four morphotypes described here represent at least four different turtle species and suggest that the GEA turtle fauna is more diversified than any other fauna known from the Late Triassic to the Middle Jurassic in the world. 
Lepidosauromorpha Benton, 1983

Lepidosauria Haeckel, 1866

Rhynchocephalia Günther, 1867

Rhynchocephalia indet. (Fig. 13A-B)

Material: GEA 2-20 (Fig. 13A), one fragment of dentary bearing two incomplete teeth; GEA 2-18 (Fig. 13B), one fragment of maxilla bearing the bases of two teeth.

\section{Description}

GEA 2-20 (Fig. 13A) bears two fully acrodont teeth. Their occlusal areas are damaged. Each tooth comprises a posterior conical part that is prolonged anteriorly by a flange. The most complete flange is slightly bent lingually and it overlaps the posteromedial border of the preceding tooth. Although its occlusal edge is damaged, it may be inferred that the height of the flange decreased anteriorly. The anterior part of the flange is thickened. There is no posterior flange, therefore the fragment belongs to a dentary. Vertical shallow grooves separated by rounded ridges occur on the labial face of the teeth, but the lingual surface is smooth. Wear facets are lacking, it being understood that the occlusal parts are broken off; similarly, the bone lacks trace of wear.

GEA 2-18 (Fig. 13B) is a fragment of maxilla on which remain only the bases of two fully acrodont teeth. The section of the anterior tooth is circular, whereas the posterior tooth bears an incipient, sharp flange posteriorly. No grooves and ridges are visible on these very incomplete teeth. It is not possible to state confidently whether GEA 2-18 belongs to the same taxon as GEA 2-20, but no character is inconsistent with such a referral.

\section{Comments}

The clearly acrodont implantation of the teeth shows that these specimens belong to Rhynchocephalia. The overall morphology of the teeth, observable in GEA 2-20, is similar to that of Tingitana from the ?Berriasian of Anoual, a site that is geographically very close to Guelb al Ahmar. The anterior thickened part of the damaged flange may correspond to the anterior small cone that is present in Tingitana (Evans and Sigogneau-Russell, 1997). The vertical grooves and ridges that occur on GEA 2-20 are also present in Tingitana. However, in the latter, they are located on the lingual face whereas on GEA 2-20 they are on the labial surface. Based on the available material, the location of these grooves and ridges appears to be the only difference between GEA 2-20 and Tingitana, but such ridges occur in various rhynchocephalians and they appear to be functional, perhaps without taxonomic significance. In addition, the teeth of GEA 2-20 do not significantly differ from those of Clevosaurus, a rhynchocephalian rather widely distributed in the Triassic and Jurassic and that was reported from the Early Jurassic of Africa (Sues and Reisz, 1995).

<<Fig. 13 here>>

Squamata Oppel, 1811

Some incomplete bones bearing teeth and incomplete vertebrae represent non-ophidian squamates, i.e. lizards. 
Scincomorpha Camp, 1923

Scincomorpha indet. (Fig. 13C)

Material: GEA 2-26 (Fig. 13C), a fragment of bone bearing teeth.

Description

A fragment of bone bears two complete and two broken teeth. The teeth are clearly pleurodont, elongate and their shaft is approximately cylindrical. The lingual face of the crowns is slightly concave and clearly limited anteriorly and posteriorly by two sharp ridges, the crista mesialis and crista distalis (Richter, 1994; Kosma, 2004). Within this concave area, on one of the teeth only, two striae dominantes bound a narrower area that is salient lingually. On the other tooth, despite its close position, the striae dominantes are less marked and the surface they limit is less salient. A peculiarity of these two teeth is that there is no distinct cuspis labialis and cuspis lingualis; the apex is apparently formed by a single cusp. There are no resorption pits. The sub- or supradental shelf is broken away and the presence or absence of a sulcus dentalis cannot be determined.

\section{Comments}

The pattern of the lingual face of the crowns characterizes scincomorphans (Evans and Searle, 2002; Kosma, 2004). However, the presence of a single apical cusp, if confirmed, would be a peculiar feature. The monophyly of scincomorphans has been debated; however, the most integrative phylogenetic analysis (Gauthier et al., 2012) recovered a monophyletic Scincomorpha. Whatever may be the case (para- or monophyly), it must be stated that the earliest fossils assigned to this assemblage were formerly reported from the Bathonian of Britain (Evans, 2003); in other words, GEA 2-26 is one of the earliest representatives of the group. Scincomorphans were dominant among squamates during the Mesozoic.

?Scincomorpha indet. (Fig. 13D)

Material: GEA 2-28 (Fig. 13D), a fragment of bone bearing one complete tooth.

\section{Description}

In this specimen, the sub- or supradental shelf is damaged but it may be inferred that a sulcus dentalis was likely present. The teeth are pleurodont, slightly compressed antero-posteriorly and more robust, less elongate than those of GEA 2-26. The lingual face of the only preserved crown is of the scincomorphan type, but this cannot be definitely confirmed. An area limited by what may be striae dominans is very narrow and it markedly protrudes medially.

\section{Comments}

The assignment of this poorly preserved specimen to scincomorphans is uncertain. If it really belongs to this group, then its referral to the same taxon as GEA 2-26 should be considered. The lingual pattern of the crown is somewhat peculiar because the area between the striae dominans, if homology of these striae is right, is very salient. In addition, the significance of the tooth proportions is unknown. Although this is not very likely, it cannot be discarded that GEA 2-26 and GEA 2-28 fall within the variation range of the same tooth row. 
Anguimorpha Fürbringer, 1900

cf. Parviraptor Evans, 1994

cf. Parviraptor sp. (Fig. 13E)

Material: GEA 2-30 (Fig. 13E) and GEA 2-34, 35, 36, four vertebral centra.

Description

Four vertebral centra represent this taxon. On one of them (GEA 2-30), the left paradiapophysis is preserved. The centra are procoelous and their ventral faces are approximately rectangular and almost flat, without any trace of a keel. The lateral borders are subparallel and scarcely concave. The cotyles and condyles are oval and they are not pierced by a notochordal canal. In ventral view, the condyle is clearly narrower than the centrum; the narrowing of the posterior limit of the centrum is abrupt. A marked ridge runs on the dorsal face of the centrum, in the neural canal. The paradiapophysis is narrow anteroposteriorly and elongated dorsoventrally.

\section{Comments}

The subparallel lateral borders of the centrum, the almost flat ventral surface, the marked and abrupt narrowing anterior to the condyle, and the presence of a well marked-off ridge on the dorsal face of the centrum make up a combination of characters that is clearly reminiscent of Parviraptor (Evans, 1994, 1996). The specimens from GEA 2 differ from those of the Bathonian of Britain in lacking remains of a notochordal canal; however, the retention of this canal is only a feature of ontogenetic nature that is lacking in specimens of Parviraptor from the Late Jurassic of North America (Evans, 1996). The specimens from GEA 2 are therefore very similar to vertebrae assigned to Parviraptor; however, in view of their incomplete nature, they are only assigned tentatively to this genus.

Parviraptor is known from the Bathonian of Britain (Evans and Waldman, 1996), the Late Jurassic of Portugal and of the USA (Evans, 1996) and the Berriasian (Purbeck beds) of England. Cf. Parviraptor was reported from the Aptian/Albian of Western Siberia (Skutchas, 2006).

Indeterminate non-ophidian Squamata (Fig. 13)

Material: GEA 2-24, one incomplete maxilla (Fig. 13F); GEA 2-25, one incomplete dorsal vertebra (Fig. 13G); GEA 2-27, one proximal part of femur.

Maxilla

GEA 2-24 is the posterior portion of a left maxilla; it includes the posterior part of the prefrontal process (= facial process) and misses the posterior tip of the bone. It bears eight preserved teeth and five empty loci. Teeth are clearly, but not deeply, pleurodont. The longest tooth projects approximately one-half beyond the parapet. The bases of the more anterior teeth are slightly compressed anteroposteriorly and all teeth lack resorption pits. Tooth apexes differ from those of 
GEA 2-26 and GEA 2-28 in being rounded and in lacking any crest or stria. A shallow supradental shelf is present, but is largely broken away. It cannot be stated whether a sulcus dentalis is present.

The overall morphology of this maxilla is consistent with that of 'lizards' but also with that of albanerpetontid amphibians. However, the teeth are well preserved and their rounded tips permit to discard assignment to albanerpetontids.

\section{Vertebra GEA 2-25}

The specimen preserves the centrum, part of the left neural pedicel and the left prezygapophysis. It is slightly crushed laterally. The centrum is procoelous, narrow, hourglass-shaped and it bears a strong haemal keel. The condyle is circular. A well-marked, narrow and comparatively deep hemal keel runs on the ventral face. The paradiapophysis is broken away. The prezygapophysis lacks a prezygapophyseal process; the major axis of its articular facet is oriented anteroposteriorly, which is not frequent.

The morphology of this vertebra does not provide information about relationships among lizards. Only the anteroposterior orientation of the prezygapophyseal facet would represent a significant feature, but it may result from crushing.

\section{Femur GEA 2-27}

This fragment of femur is assigned to squamates rather than to choristoderes because its trochanter is more salient and more perpendicular to the main articulatory surface than in the latter.

Conclusion on the non-ophidian squamates from Guelb el Ahmar

The teeth recovered from the locality GEA 2 correspond to two, perhaps three, lizard taxa. Moreover, cf. Parviraptor should be added to these taxa; it is represented only by vertebrae, but teeth of this lizard known from other localities are quite different from those found at GEA 2. Therefore, three or four species of squamates are present at GEA 2. These lizards belong to at least two squamate groups: Scincomorpha and Anguimorpha.

Prior to our report, the earliest occurrences of squamates whose geological age is confirmed were from the Bathonian of Britain (Evans, 1998; Evans et al. 2006) and from the Bathonian of Western Siberia (Skutchas, 2006). Unfortunately, the Siberian fossil remains undescribed. Older fossils from North America (Early Jurassic) and India (Triassic and Early Jurassic) were referred to squamates, but either their assignment to squamates or their geological age are questionable (Evans, 2003; Hutchinson et al., 2012; Prasad and Manhas, 2007; Rage, 2013). Therefore, the earliest confirmed occurrences of squamates are in the Bathonian of Morocco (GEA 2), Britain and Western Siberia.

<<Fig. 14 here>> 


\section{cf. Choristodera indet. (Fig. 14A-B)}

Material: GEA 2-31, one fragmentary dentary (Fig. 14A); GEA 2-23 and GEA 2-37, two centra of dorsal vertebrae (Fig. 14B); GEA 2-38, one centrum of an anterior caudal vertebra; perhaps GEA 2-39, centrum of a dorsal vertebra.

\section{Description}

Two centra of dorsal vertebrae are amphicoelous and the rims of their cotyles are relatively thick. Centra are longer than wide. As is typical in several choristoderes, the neurocentral suture is open, which accounts for the absence of the neural arches. The suture passes across the synapophyses. A sagittal ridge runs along the floor of the neural canal. A more-or-less rounded sagittal keel is present on the ventral face. In GEA 2-37, a notch for the neural arch pedicle is visible at the posterior extremity of each neurocentral suture. GEA 2-38 bears a sagittal groove on its ventral face, which is a characteristic of caudal vertebrae.

A fragment of dentary is consistent in size with the vertebral centra. Its ventral border is straight. It bears subthecodont or thecodont teeth. The basal part of one tooth shows that the teeth were comparatively high and conical. On the lingual face, the subdental shelf (sensu Rage and Augé, 2010) is thick. Its medial face is flat, i.e. the preserved area likely corresponds to a part of the facet for the splenial. The labial face is damaged. However, on a preserved area of the dorsal half, two narrow and elongate depressions are aligned horizontally. In addition, two rounded pits are present.

\section{Comments}

The combination of an open neurocentral suture, synapophyses divided by the suture, presence of a notch for the neural arch pedicel, and amphicoely (Evans, 1991) is clearly reminiscent of the small choristodere from the Bathonian of Britain, which was referred to Cteniogenys (Evans, 1991; Evans and Milner, 1994). On the dentary, the thick subdental shelf and the elongate depressions that look like short grooves on the labial face also recall the choristodere from the Bathonian of Britain (Evans, 1990). The association, in the locality, of vertebral elements and of a fragmentary dentary that recall those assigned to choristoderes in the Bathonian of Britain suggests that the group is present at GEA. However, in view of the fragmentary nature of the specimens, the identification needs confirmation based on more complete material.

Choristoderes were diapsids that lived in freshwater or were amphibious. They are known from the Middle Jurassic to the early Miocene (Matsumoto and Evans, 2010). The earliest representative of the choristoderes is Cteniogenys from the Bathonian of England and Scotland (Evans, 1990; Evans et al., 2006) and the fossil from GEA 2 if its allocation is confirmed. In addition, the fossil from GEA 2 would be the first choristodere recovered from a Gondwanan continent (Matsumoto et al., 2013). 
Archosauria Cope, 1870

Dinosauria Owen, 1842

Saurischia Seeley, 1888

Theropoda Marsh, 1881

Theropoda indet. (Fig. 14C)

A few nearly complete teeth showing a labiolingually compressed crown and serrated mesial and distal carinae can be assigned to a small, indeterminate theropod. No more precise identification is possible, but their morphology is reminiscent of some teeth described from the Bathonian of England (Evans and Milner, 1994). Similar teeth also occur in the Ksar Metlili locality (Knoll and RuizOmeñaca, 2009).

Ornithischia Seeley, 1888

Thyreophora Nopcsa, 1915

cf. Stegosauria Marsh, 1877

cf. Stegosauria indet. (Fig. 14D)

A single, poorly preserved tooth can be referred to a thyreophoran dinosaur, probably a stegosaur, because of the presence of a basal cingulum and a few well-developed denticles. A similar tooth referred to a stegosaurian has been described from the Bathonian of England (Metcalf et al., 1992; Metcalf and Walker, 1994).

Ornithischia indet. (Fig. 14E)

A complete tooth with a recurved crown bearing four small denticles at the base of its distal carina may belong to an indeterminate ornithischian dinosaur (Ornithopoda?). The enamel surface displays some slight longitudinal folds. Similar teeth were described from the late Middle Jurassic of Portugal as a new hypsilophodontid ornithopod, Alocodon kuehnei (Thulborn, 1973: fig. 2, 5a), now regarded as a nomen dubium, and from the Bathonian of southern France (Kriwet et al., 1997: fig. $7 m)$.

Pterosauria Kaup, 1834 (Fig. 14F-I)

Rhamphorhynchidae Seeley, 1870

Rhamphorhynchidae indet. (Fig. 14 F)

A first pterosaurian morphotype corresponds to teeth with a slender, labiolingually compressed, slightly recurved crown (Fig. 14F). Sharp anterior and posterior carinae are present, and most of the crown (except near the base) is covered by a thin enamel layer. Similar teeth have been described in various Middle-Late Jurassic assemblages of vertebrate microremains and assigned to the Rhamphorhynchidae (Wiechmann and Gloy, 2000; Flynn et al., 2006; Vullo et al., 2014).

Pterosauria indet. (Fig. 14G-I) 
A second pterosaurian morphotype corresponds to shorter and more robust teeth (Fig. 14GI). The enamel layer covers only the apical half of the crown and is also present more basally along anterior and posterior carinae. Some short vertical folds can develop lingually at the base of the enamelled portion. Such teeth are present in wukongopterids (e.g., Darwinopterus robustodens; Lü et al., 2011), a group of basal monofenetratans known exclusively from the Middle Jurassic of China (Wang et al., 2010). However, similar teeth can also be observed in some Middle Jurassic rhamphorhynchids (e.g., Jianchangopterus; Lü and Bo, 2011) and Late Jurassic pterodactyloids (e.g., Pterodactylus, Germanodactylus; see Wang et al., 2008). Therefore, a definitive assignment of this second morphotype is not possible.

<<Fig. 15 here>>

Crocodyliformes Hay, 1930

Atoposauridae Gervais, 1871

Theriosuchus Owen, 1879

\section{cf. Theriosuchus sp. (Fig. 15 A-D)}

Numerous small teeth can be assigned to this family of dwarf crocodyliformes. Anterior teeth (Fig. 15 A-B) show a relatively high, lanceolate and slightly recurved crown, while more posterior teeth (Fig. $15 \mathrm{C}$ ) have a labiolingually compressed, leaf-shaped crown displaying jagged carinae. The ornamentation, more marked in anterior teeth, consists of longitudinal ridges present on both labial and lingual faces. In posteriormost teeth (Fig. 15D), the crown is very low and labiolingually compressed, the ornamentation is reduced to a few apical ridges on the lingual face, and the carinae bear more distinct denticles. However, this denticulation corresponds in fact to "false ziphodonty" sensu Prasad and Lapparent de Broin (2002). Similar variation in tooth morphology (i.e., gradient heterodonty) is known in the Late Jurassic to Late Cretaceous atoposaurid genus Theriosuchus, in which posteriormost teeth show a more or less developed pseudoziphodont condition (Owen, 1879; Thies et al. 1997; Schwarz and Salisbury, 2005; Schwarz-Wings et al., 2009; Martin et al., 2010, 2014; Lauprasert et al., 2011; Vullo et al., 2014). Therefore, the GEA atoposaurid is tentatively referred to cf. Theriosuchus sp. This new occurrence adds to the earliest occurrences of atoposaurids, corresponding to isolated teeth (including Theriosuchus-like teeth) from the Bathonian of UK and France (Evans and Milner, 1994; Kriwet et al., 1997; Evans et al., 2006).

Atoposauridae indet. (Fig. 16 A-B)

Some teeth are reminiscent of those described here as cf. Theriosuchus sp., but they are slightly larger and show a less pronounced ornamentation.

Thalattosuchia Fraas, 1901

Teleosauridae Geoffroy Saint-Hilaire, 1831

Teleosauridae indet. (Fig. 16 C)

At GEA 2, the microremains assemblage includes abundant small slender teeth ornamented with fine longitudinal rigdes that tend to converge apically (Fig. 16C). The crown is slightly sigmoid in 
shape and carinae are weak to absent. They closely resemble those observed in some longirostrine forms of thalattosuchians such as Pelagosaurus, Teleosaurus and Steneosaurus (Vignaud, 1997; Pierce and Benton, 2006), corresponding to the morphotype A3 defined by Vignaud (1997). Their small size (generally between 5 and $8 \mathrm{~mm}$ ) would suggest that they belonged to neonate or juvenile individuals. Similar teeth are also very common in the Ksar Metlili assemblage; Knoll (2000) noted a "morphological resemblance to teeth of teleosaurid crocodiles" but finally tentatively assigned these teeth to a gnathosaurine pterosaur. In Morocco, teleosaurids remains were reported from the Bathonian of El Mers (Termier et al., 1940; Lapparent, 1955), but a direct comparison with the material from Ksar Metlili is not easy.

Thalattosuchia indet. (Fig. 16 D-G)

Some large, robust crocodilian teeth also occur (Fig. 16D) at GEA 3. They are ornamented with an irregular pattern of ridges that is clearly more developed lingually than labially. In the same level, several poorly preserved skeletal elements belonging probably to a single individual have been collected. Best-preserved elements consist of amphicoelous vertebrae, a distal end of a femur and osteoderms (Fig. 16E-G). All these remains may belong to a thalattosuchian crocodyliform (?metriorhynchid).

<<Fig. 16 here>>

Diapsida indeterminate

Material: GEA 2-40 to GEA 2-45, six vertebral centra.

Comments

The centra are similar to those of the presumed choristodere from the locality, although most are clearly larger; the centrum length of the largest specimen is over $8 \mathrm{~mm}$, while the longest choristodere centrum does not reach $5 \mathrm{~mm}$. However, in these specimens the neural arch was fused to the centrum (although it is broken away in all). These vertebrae perhaps belong to choristoderes, in which the neural arch may fuse to the centrum in old individuals, but they lack unquestionable character that would demonstrate such a referral. As they are, with a fused neural arch, the vertebrae do not clearly differ from stem squamates or stem lepidosaurians (Waldman and Evans, 1994).

\section{Synapsida Osborn, 1903}

Mammalia Linnaeus, 1758

Two or probably three specimens of mammals were found in the Bathonian brown marls of the site GEA 2.

Cladotheria McKenna, 1975

Zatheria McKenna, 1975 
Amphitheriida Owen, 1846

Amphitheriidae Owen, 1846

Amphitheriidae indet. (Fig. 17 A-C, H-O; Fig. 18 C)

Material: GEA 2-1, fragment of right dentary of a juvenile individual with an anterior lower premolar $\left(P_{2}\right.$ or $P_{3}$ ? $)$ and a replacing posterior premolar $\left(P_{3}\right.$ or $P_{4}$ ? $)$ still in crypt. GEA 2-32: fragment of an edentulous right dentary, probably middle-posterior part. It is referred to the same species represented by specimen GEA 2-1.

\section{Description}

The specimen GEA 2-1 is the most informative mammal remains found in Guelb el Ahmar. It is the basis for our description and identification of an amphitheriid in the Middle Jurassic beds of the Anoual Syncline. It is a fragment of a tiny right lower jaw (max length $=2.1 \mathrm{~mm}$ ) of a juvenile individual bearing two adjacent premolars, one fully erupted, and the following still in crypt in the dentary bone.

The CT scan shows the absence of a replacement tooth in the mandibular corpus below the erupted premolar, indicating it is a definitive tooth. This unworn premolar was probably recently erupted before the death of the individual. A replacing premolar (unerupted tooth) occurs at the locus posterior to this premolar. The erupted tooth and the posterior tooth in crypt are indeed definitive premolars. GEA 2-1 provides evidence that among these two adjacent premolars, the ontogenic development and functional role of the posteriormost preserved premolar was noticeably delayed with respect to the anterior one.

One striking feature of the specimen GEA 2-1 is that its teeth are located markedly labially on the lower jaw, far from the lingual flank that is noticeably inflated. The CT scan (Fig. 17, I and L) shows that that the roots apices of the erupted premolar are curved lingually for connection with the mandibular canal that is located markedly lingually.

<<Fig. 17 here $>>$

- Anterior erupted premolar: $\mathrm{P}_{2}$ or $\mathrm{P}_{3}$ ?

The erupted premolar has two roots that are well separated but not divergent (Fig. 17 M, 0). The two roots have similar size. The occlusal outline of the crown is narrow and elongated (Fig. $17 \mathbf{~ N}$ ). The overall crown morphology is simple, which suggests an anterior premolar, either a $\mathrm{P}_{2}$ or a $\mathrm{P}_{3 \text { ? }}$. The crown is still unworn, indicating it was recently erupted. The dentary preserves an alveolus anterior to this premolar. It is of similar small size indicating that the more anterior tooth was not a canine; this supports the interpretation that the erupted premolar on the dentary GEA 2-1 is posterior to $\mathrm{P}_{1}$, corresponding most probably to a $\mathrm{P}_{2}$ or a $\mathrm{P}_{3}$ ?.

The crown morphology of the preserved $\mathrm{P}_{2}$ or $\mathrm{P}_{3}$ ? is sharp with acute cusps and long crests. The main cusp (protoconid) is broken. Its preserved proportions indicate a large and high cusp that was mesially located on the crown. The protoconid is flanked by a clearly distinct anterior cusp, the paraconid, and a well developed and crestiform talonid. All cusps and crests are aligned mesiodistally, and located more or less central transversally on the crown. The paraconid was large and 
prominent mesially. The talonid is elongated. It bears in a small posterior cusp (hypoconid?) from which a small but sharp and high anterior crest extends toward the main cusp, although it does not arise on it. No distinct cingulids are seen on the tooth, but the corresponding area of the crown is badly preserved, especially on the lingual side.

- Replacing tooth - anterior lower premolar: $\mathrm{P}_{3}$ or $\mathrm{P}_{4}$ ?

Although still in crypt, the crown morphology of the unerupted tooth has been reconstructed with the help of 3D modeling from the CT scans (Fig. $17 \mathrm{M}-\mathbf{0}$ ).

The tooth is close in size to the erupted premolar, but it seems less elongated mesio-distally. The roots are absent, and at least in part broken. The crown is simple, mostly dominated by a large, high and sharp cusp (protoconid) that is compressed labio-lingually. It is proportionally slightly larger than in the erupted premolar, although the overall sizes of the two teeth are similar. Its apex is sharp and slightly tilted lingually. It only begins to erupt from the alveoli behind the erupted premolar. The profile of the main cusp (protoconid) is asymmetric: 1) labio-lingually with a well convex labial flank, in contrast to the subplanar lingual flank; 2) mesio-distally with a high and subvertical posterior flank, in contrast to a more inclined convex mesial flank. The protoconid bears a long and high posterior crest. There is no distinct metaconid. The talonid is broken. As a whole, the anterior premolar in this species is a simple and asymmetrical triangular blade. No cingulum is distinct in this tooth, but again the corresponding area is poorly preserved in this tooth.

\section{- Dentary}

GEA 2-1 corresponds to an anterior fragment of dentary. It bears a mental foramen that opens under the anterior root of the erupted premolar. A CT scan examination shows that it is linked to the mandibular canal by a transverse canal that is poorly oriented distally; it is linked to the anterior root of the erupted premolar and follows downward the labial side of this root toward the mandibular canal. The mandibular canal is located markedly lingually and it is large in transverse section (Fig. 17 L). The dentary is typically inflated lingually, which probably correlates with the large mandibular canal (Fig. 17 L). Correlatively, 1) the teeth and the alveolar row are strikingly located asymmetrically on the labial side of the jaw, 2) the root apex is curved lingually for connection with the mandibular canal (Fig. 17 L). The latter character is striking. There is no distinct Meckel's groove in GEA 2-1.

Table 1. Mammalia, Amphitheriidae g., sp. indet.: measurements of GEA 2-1 and GEA 2-32 (mm). Measurements were made under binocular Measuroscope (Nikon, MM400 SL), except for length and width of the replacing tooth $\mathrm{P}_{2}$ or $\mathrm{P}_{3}$ of GEA 2-1 that was measured on the $3 \mathrm{D}$ model of the tooth with the help of the program MIMICS. L= Length: $\mathrm{W}=$ width. *maximal preserved length.

\begin{tabular}{llcc}
\hline & Specimen & $\mathrm{L}$ & $\mathrm{W}$ \\
\hline $\mathrm{P}_{2}$ or $\mathrm{P}_{3}$ (erupted) & GEA 2-1 & 0.75 & 0.2 \\
$\mathrm{P}_{3}$ or $\mathrm{P}_{4 \text { ? }}$ (in crypt) & GEA 2-1 & $>0.49$ & 0.2 \\
Dentary & GEA 2-1 & $2.1^{*}$ & 0.8 \\
Dentary & GEA 2-32 & $2.65^{*}$ & 0.85 \\
& & & $\begin{array}{c}\text { (max. } \\
\text { width) }\end{array}$ \\
Post. + middle & GEA 2-32 & 1.1 & 0.45 \\
alveoli & & & \\
\hline
\end{tabular}




\begin{tabular}{llll}
\hline $\begin{array}{l}\text { Middle + ant. } \\
\text { alveoli }\end{array}$ & GEA 2-32 & 1.1 & 0.45 \\
\hline
\end{tabular}

GEA 2-32 (Fig 17 D-G; Fig. 18 D-F) is a fragment of right lower jaw that has lost the teeth, and bears three empty alveoli that are filled by sediment (i.e., teeth were not broken during screeningwashing but during taphonomical processes). It is closely reminiscent of GEA 2-1, and corresponds to the more posterior part of the lower jaw. Several features suggest it could belong to same individual as GEA 2-1: similar size and proportions (see Fig. 17), similar preservation state of the bone (including color), and general morphology. The morphological affinity of GEA 2-32 and GEA 2-1 lays especially in the tooth row that is shifted on the labial side of the dentary.

The three alveoli seen in GEA 2-32 slightly increase in size posteriorly. Given the larger size with respect to GEA 2-1, they might correspond to posterior premolars and/or anteriormost molars. A radiograph (Fig. 16 F-G) shows that broken roots are present at least in the anteriormost alveolus, and that there is no evidence of replacing teeth. This supports the view that the teeth lost in GEA 232 were definitive teeth and probably molars. According to Lopatin and Averianov (2007), the absence of any trace of the mental foramen would suggest that preserved alveoli of GEA 2-32 are those of posterior teeth to $M_{1}$, because the posterior mental foramen is located below $M_{1}$ in amphitheriids. However, we do not know the variability of this feature in amphitheriids. The presence in GEA 2-32 of permanent molars, as supported by the radiograph, does not exclude it belonging to the juvenile individual represented by GEA 2-1. As in GEA 2-1, there is no distinct Meckel's groove in GEA 2-32.

<<Fig. 18 here>>

\section{Comparison}

Among Mesozoic mammals, the general morphology of GEA 2-1 most closely resembles the stem zatherian Amphitheriidae (Cladotheria), known from the Middle Jurassic.

The amphitheriids are pretribosphenic primitive therian mammals (e.g., Martin, 2002). They are the basalmost stem mammals belonging to the lineage that includes modern therian mammals. Three to four Amphitheriidae genera are known: Amphitherium de Blainville, 1838, Amphibetulimus Lopatin and Averianov, 2007, Nanolestes Martin 2002 and Palaeoxonodon Freeman, 1979. The familial position of Palaeoxonodon, initially referred to Peramuridae, remains debated (e.g., Sigogneau-Russell, 2003; Davis, 2011).

GEA 2-1 displays diphyodont premolars. This is the earliest evidence of the diphyodonty in Cladotheria, that was previously documented by Nanolestes and the Dryolestida (Martin 1997, 2002). However, Butler and Clemens (2001) already sugested that amphitheriids were therian-like in the dental replacement with diphyodont premolars, based on examination of wear pattern of permanent teeth.

Several features of GEA 2-1 (lower jaw, and anterior premolars) recall the amphitheriids:

- The position of the anterior mental foramen, under the third or second postcanine locus;

- The elongated occlusal outline of the premolar crown ;

- The sharp tooth morphology; 
- The large and elongated talonid, that bears a long mesio-distal crest (e.g., Butler and Clemens 2001; Davis, 2011).

The large and elongated talonid bearing a long crest is especially distinct from other stem zatherians such as dryolestidans (e.g., Davis, 2011; Lopatin and Averianov, 2007; Kielan-Jaworoswska et al., 2004). It is a feature of the type-genus Amphitherium (Bathonian of England), which is only known by the lower jaw and lower dentition. The labial position of the talonid cusp of the erupted teeth is also a feature seen in permanent premolars of amphitheriids. Moreover, the posterior root of this tooth is not much smaller than its anterior root in contrast to dryolestidans (KielanJaworoswska et al., 2004). The small size of the teeth preserved in GEA 2-1 is comparable to the anterior premolars of Amphitherium.

As far as the specimen GEA 2-1 can be compared, the closest genus to the Moroccan species is Amphitherium known from the same Bathonian age. The definitive lower premolar preserved in crypt in GEA 2-1 closely resembles the two-rooted $\mathrm{P}_{2}$ and $\mathrm{P}_{3}$ of Amphitherium (Simpson, 1928; Butler and Clemens, 2001) and also of Nanolestes, especially in the crown dominated by a similar asymmetrical triangular and blade-like main cusp.

The Moroccan material, however, show several singular features with respect to known amphitheriids. The apparent absence of a lingual cingulid in the teeth is distinctive from the premolars of Amphitherium. However, this trait is poorly preserved in teeth seen in GEA 2-1 (e.g., lingual flank of the unerupted premolar), and it needs to be checked on more complete material. The roots are not swollen at the upper alveoli level in GEA 2-1, in contrast to the molars and premolars of Amphitherium. The absence of a Meckel's groove in GEA 2-1 and GEA 2-32 is another distinct feature with respect to known morphology of Amphitherium.

The most distinctive and remarkable morphological feature of GEA 2-1 is actually exemplified by a suite of likely related traits: the labial position of the teeth on the dentary, the root apex curved lingually, the lingual position of the mandibular canal, and the inflated ventro-lingual side of the dentary (Fig. 17 L). This peculiar morphology was evidenced thanks to the computed microtomography of the material. Its distribution is unknown among primitive zatherians and in early mammals in general. It has so far never been mentioned, especially in Jurassic mammals.

\section{Comment}

GEA 2-1, and the probably conspecific specimen GEA 2-32, probably represent a new amphitheriid cladotherian close to Amphitherium. This is actually the first amphitheriid ever found in South Tethyan provinces (Gondwana). Together with the amphitheriids from the Middle Jurassic of England, the material from Guelb el Ahmar is one of the earliest known stem zatherians; it shows indeed that the earliest representatives of the lineage of therian mammals and their pretribosphenic stem groups were present in Gondwanan provinces such as Africa, as they were in Laurasia. It is noteworthy that Africa also yielded some of the earliest known tribosphenic mammals (Tribotherium, Hypomylos), actually from the same syncline of Anoual (Ksar Metlili site; Sigogneau-Russell, 1991a, 1995).

\section{cf. Mammalia}




\section{cf. Dryolestida indet. (Fig. 17 P-Q)}

This species is documented by specimen GEA 2-33 which is a fragment of a tooth bearing one cusp and one root. This is a relatively large tooth (maximal preserved length: $3 \mathrm{~mm}$ ) by Mesozoic mammal standards. The preserved cusp has a more or less circular occlusal outline and bears two low crests. It is low and wide, resulting in a stout construction. The cusp and the root are not strictly symmetric. The root is large and high (at least 3 times higher than wide). It is more expanded on one side than on the other, opposite side. The crown is slightly prominent above the root.

This species belongs to a taxon different from that of GEA 2-1 and 2-32, as evidenced by the larger size (height of cusp + root: $3 \mathrm{~mm}$; $L$ and $W$ of the cusp: $0.8 \mathrm{~mm}$ and $1 \mathrm{~mm}$ ), and the robust morphology. Comparison of specimen GEA 2-33 recalls more closely dryolestidans such as Donodon perscriptoris Sigogneau-Russell, 1991, a large species that is known in the Anoual Syncline ?Berriasian site of Ksar Metlili. The large size, the robust construction (cusp low and large), general morphology, and large root, all closely resemble dryolestidan molars. The asymmetric morphology of the root is reminiscent in particular of the paracone of a left upper molar of dryolestidans: on the distal side it is extended from the paracone to the labial side (metastyle), and on the mesial side it is well distinct (rounded) and separated from another (but broken) more labial root (parastyle root). As in dryolestidan upper molars, the paracone preserves two crests of different morphology: the mesial crest (paracrista) is the most vertical, and the posterior crest is less steep and bears a trace of a cuspule (metacone?) that is prominent posteriorly.

The identification of GEA 2-33 as a broken upper molar of a large dryolestidan, although supported by some morphological details, remains tentative, pending for additional and less fragmentary material. 


\section{Discussion}

The Guelb el Ahmar sites yielded one of the very few vertebrate faunas known from the Jurassic in all Gondwanan continents and from the Middle Jurassic in the world. This is especially true for microvertebrate assemblages with mammals (Tables 3 and 4).

6.1 Faunal diversity and main characters of the Guelb el Ahmar vertebrate fauna

Table 2. Faunal list of the vertebrate taxa from the Guelb el Ahmar locality, Anoual Formation, Bathonian, eastern Morocco.

\begin{tabular}{ll}
\hline Taxa & Locus \\
\hline OSTEICHTHYES & \\
- Lepisosteiformes, Lepidotes sp. or Scheenstia sp. & GEA 1, 3 \\
- Lepisosteiformes, cf. lonoscopiformes indet. & GEA 1, 2, 3 \\
- Osteoglossiformes indet. & GEA 2 \\
- Actinistia, Mawsoniidae indet. & GEA 1, 2, 3 \\
- Dipnoi, Arganodus sp. & GEA 2 \\
- Pisces indet. & GEA 3 \\
& \\
AMPHIBIA & GEA 2 \\
- Albanerpetontidae indet. & GEA 2 \\
- ?Caudata indet. & GEA 2 \\
- ?Lissamphibia incert. sed. & \\
& \\
TESTUDINATA & GEA 2, 3 \\
- Testudinata indet., 4 spp. & \\
LEPIDOSAUROMORPHA & GEA 2 \\
- Rhynchocephalia indet. & GEA 2 \\
- Scincomorpha indet., 2 or 3 spp. & GEA 2 \\
- Anguimorpha, cf. Parviraptor sp. & GEA 2 \\
- Squamata indet. & \\
ARCHOSAUROMORPHA & GEA 2 \\
- cf. Choristodera indet. & GEA 2 \\
- Theropoda indet. & GEA 2 \\
- Thyreophora, cf. Stegosauria indet. & GEA 2 \\
- Ornithischia indet. & GEA 2 \\
- Rhamphorhynchidae indet. & GEA 2 \\
- Pterosauria indet. & GEA 2 \\
- Atoposauridae, cf. Theriosuchus sp. & GEA 2 \\
- Teleosauridae indet. & GEA 3 \\
- Thalattosuchia, ?Metriorhynchidae indet. & \\
MAMMALIA & GEA 2 \\
- Cladotheria, stem Zatheria, Amphitheriidae indet. & \\
- cf. Cladotheria, cf. Dryolestida indet. & \\
\hline &
\end{tabular}


Faunal composition of the vertebrate assemblage

The Guelb el Ahmar fauna has yielded a well diversified microvertebrate fauna including at least 29 species, most coming from the GEA 2 locus. This is currently one of the most diversified vertebrate fauna described from the Jurassic of Africa, along with those of the Early Jurassic of southern Africa (Milner et al., 1994; Kielan-Jaworowska et al., 2004; Knoll, 2005). Several taxa show a noticeable diversity. This is especially true for the archosauromorphs and the lepidosaurians. The diversity of the chelonians (4 species), even if they remain not formally identified, is noteworthy for such an old age. Chelonians and crocodilians are moreover the most frequent and the dominant vertebrates in the macrofauna.

The Guelb el Ahmar fauna is characterized by the absence of selachians. Even if we cannot exclude biases of sample and/or of taphonomic origin, the absence (or at least scarcity) of the selachians in Guelb el Ahmar is significant and is probably related to the lacustrine depositional environment. The fauna also noticeably lacks anuran amphibians despite the lacustrine environment of GEA.

The fauna includes among the earliest known representatives of several important taxa: osteoglossiform fishes, albanerpetontid and caudate amphibians, squamates (scincomorphans, anguimorphans), cladotherian mammals, and likely choristoderes. Beside the Guelb el Ahmar fauna, the earliest occurrence of these taxa is generally from the Bathonian of Britain.

The albanerpetontid and the salamander (Caudata) from Guelb el Ahmar are among the very few known in Gondwana, and the choristoderes, if confirmed at GEA, were previously unknown in Africa and Gondwana.

The Guelb el Ahmar fauna yielded the only known mammals from the Middle Jurassic of Africa. As a whole, the Middle Jurassic is the most poorly known period of the evolution of the mammals (Kielan-Jaworowska et al., 2004). The taxa identified in GEA are the earliest known cladotherians (the clade of the modern therian mammals) in Africa. They include a stem zatherian and a possible dryolestidan, taxa that are both known also in the Ksar Metlili fauna from Anoual Syncline upper levels. To be noted, the mammals although rare in the site are not only represented by isolated teeth, but also by fragments of jaws.

\section{Paleoecology and paleoenvironments}

The lacustrine freshwater environment of Guelb el Ahmar deposits (Haddoumi, 1998) is supported by the presence of several aquatic (freshwater) taxa: palynoflora, charophytes, gastropods, dipnoan and mawsonid fishes, lissamphibians, and choristoderes if their presence is confirmed. The marked predominance of non-lepisosteid lepisosteiform fishes (Lepidotes or Scheenstia) should be also underlined, but these taxa occur in both marine and freshwater environments. Thalattosuchian remains are among the rare components of the GEA fauna with marine affinities. This suggests that either there are marine influences in GEA, or the local Middle Jurassic thalattosuchians are euryhaline. Turtles are diversified and their remains are abundant at the GEA locality. Their association with other aquatic taxa suggests that they were very likely denizens of the local freshwater environment. They confirm that the first aquatic turtles were already diversified during the Middle Jurassic (Anquetin et al., 2009). 
Terrestrial vertebrates (lizards, pterosaurs, dinosaurs, mammals) are less abundant than aquatic taxa, but are not rare. They are known by both teeth and osseous remains, which are often broken but not eroded. They have been transported from the adjacent inland.

The abundance and large size of the trunks in the Anoual Formation argue for the presence of local forests (Haddoumi, 1998) and for rather humid (non-arid) conditions. The wood association found in the Jurassic deposits indicates stable climatic conditions and an even although low level of moisture. Philippe et al. (2003), based on the wood of Metapodocarpoxylon from the Jurassic of Morroco, suggested the occurrence of tropophile forests under a summer-wet climate.

6.2. Faunal affinities, paleobiogeographical relationships

Table 3. Main Jurassic microvertebrate localities known in Africa and other Gondwanan continents.

\begin{tabular}{|c|c|c|}
\hline Localities & Age & References \\
\hline Tendaguru, Tanzania & Late Jurassic & Heinrich $(1998,1999,2001)$ \\
\hline $\begin{array}{l}\text { Mugher Mudstone Jema River, } \\
\text { Ethiopia }\end{array}$ & Late Jurassic & Goodwin et al. (1999); Clemens et al. (2007) \\
\hline Guelb El Ahmar, Morocco & $\begin{array}{l}\text { Middle Jurassic } \\
\text { (Bathonian) }\end{array}$ & Haddoumi et al. (2008); this work \\
\hline $\begin{array}{l}\text { Ambondromamy, Mahajanga } \\
\text { basin, Madagascar }\end{array}$ & $\begin{array}{l}\text { Middle Jurassic } \\
\text { (Bathonian) }\end{array}$ & Flynn et al. ( 1999,2006$)$ \\
\hline Queso Rallado, Argentina & Early Jurassic & $\begin{array}{l}\text { Rauhut et al. (2002); Martin and Rauhut (2005); } \\
\text { Rougier et al. (2007); Cuneo et al. (2013) }\end{array}$ \\
\hline Kota Fm, India & $\begin{array}{l}\text { Early to Middle } \\
\text { Jurassic }\end{array}$ & Prasad and Manhas (2002); Parmar et al. (2013) \\
\hline Lesotho, South Africa (div. loc.) & Early Jurassic & $\begin{array}{l}\text { Milner et al. 1994; Kielan-Jaworowska et al. 2004; } \\
\text { Knoll, } 2005\end{array}$ \\
\hline
\end{tabular}


Table 4. Taxa from GEA recorded in other Middle Jurassic vertebrates sites from Gondwana. The comparison does not include the poorly known Early Jurassic faunal assemblage of Queso Rallado, Argentina. Taxa in parentheses are different from those of GEA. ${ }^{(1)}$ Caudata and Rhynchocephalia are reported in Ambondromamy, but the determination is wrong (see text); ${ }^{(2)}$ different taxon from that of GEA.

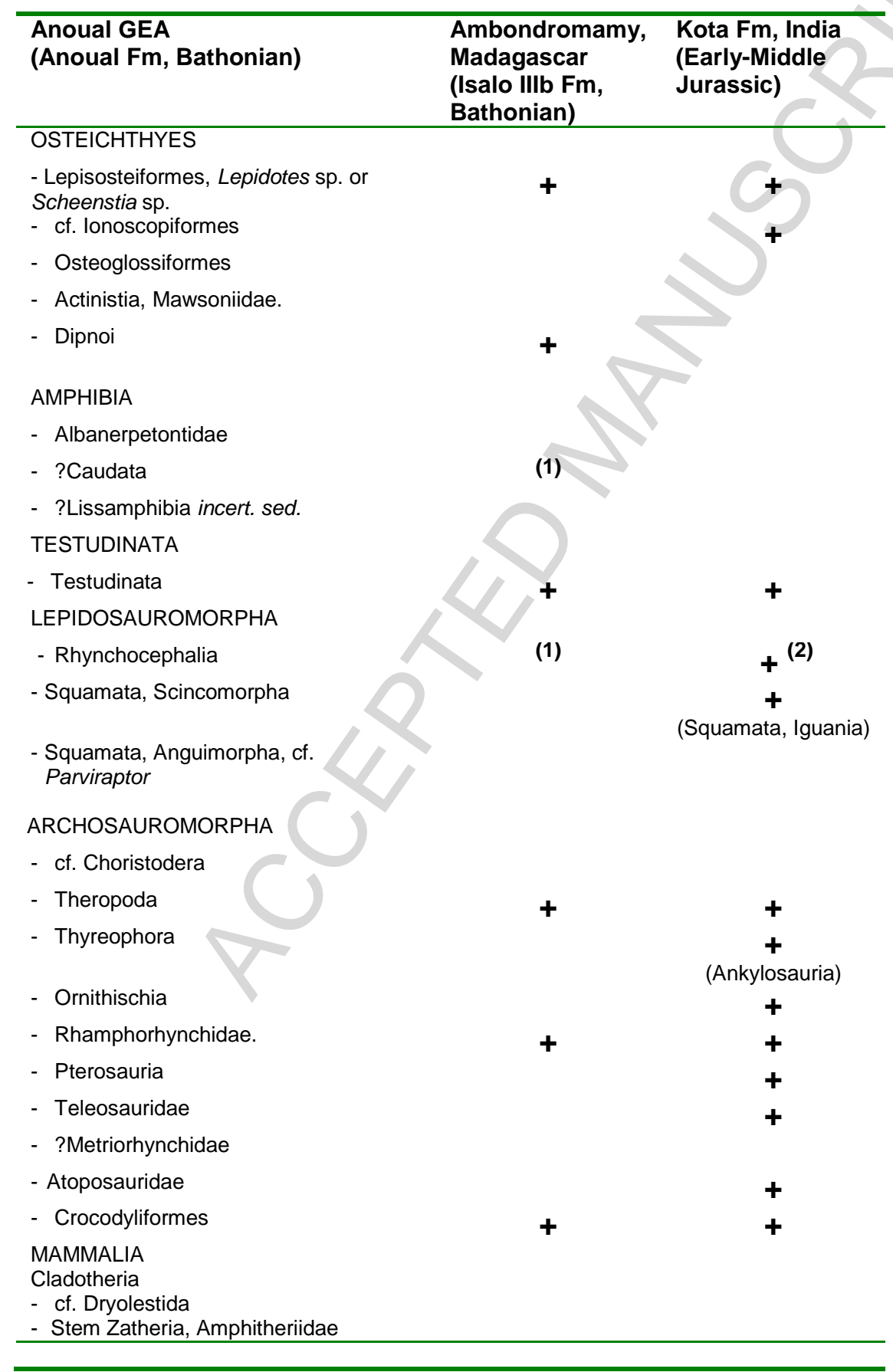


Table 5. Taxa from GEA recorded in Middle Jurassic sites from Laurasia. Taxa in parentheses are different from those of GEA.

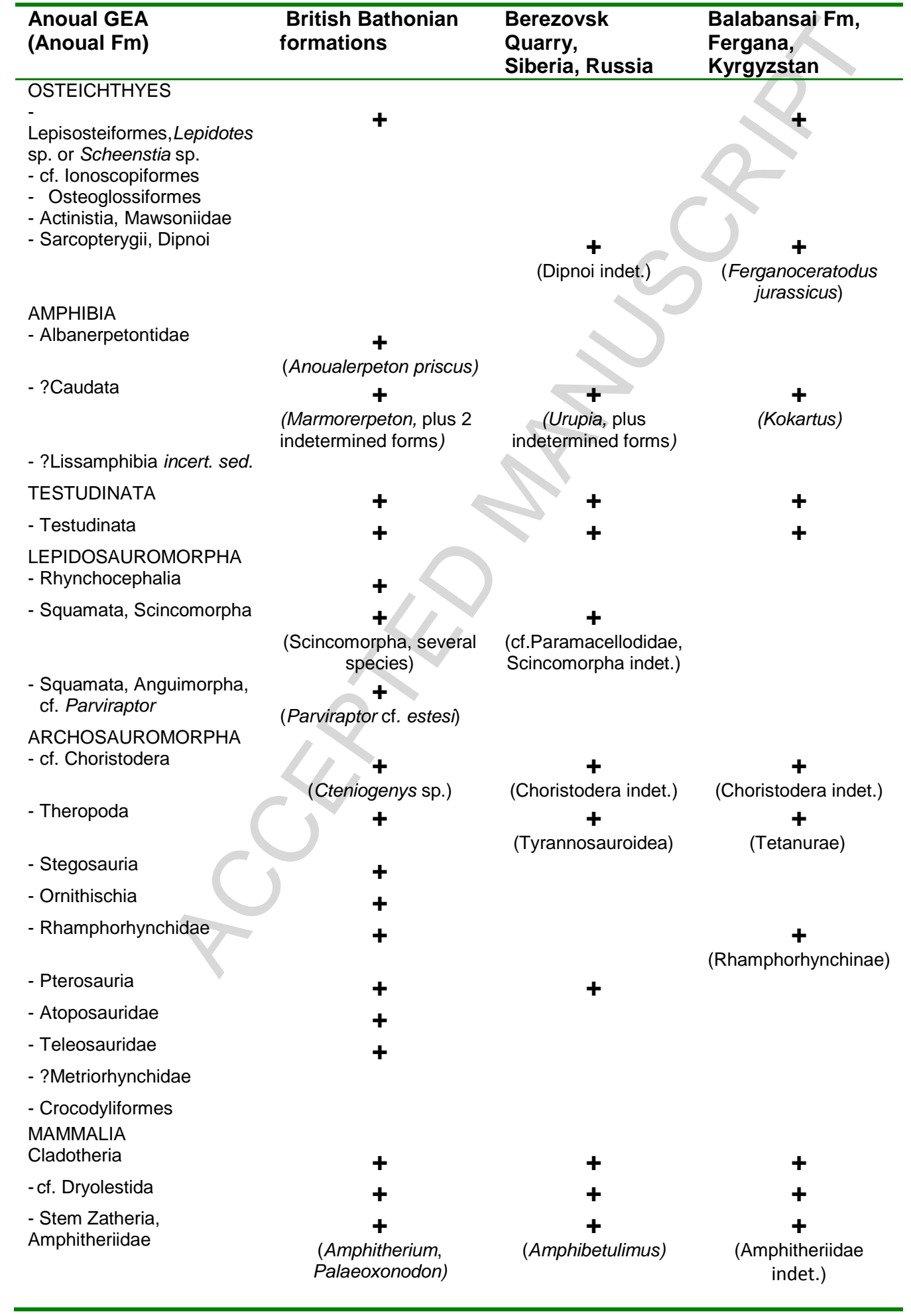

Comparisons of the GEA fauna with contemporaneous faunas from Gondwana (Table 3) and Laurasia are summarized in Tables 4 and 5. 
- Taxa with Pangean or cosmopolitan distribution

Taxa from GEA with cosmopolitan distribution are represented by non-lepisosteid lepisosteiform fishes (Lepidotes or Scheenstia). The ionoscopiform fishes are also widely distributed in Europe, Africa, and North and South America from the Middle Triassic to the Late Cretaceous (e.g., Vullo and Courville, 2014; Xu et al., 2014). The Mawsoniidae had a Triassic Pangean distribution (Miguel et al., 2014). They diversified with vicariant evolution during breakup of Pangea and Gondwana. The mawsoniid from GEA remains too poorly known to assess its exact affinities.

The general composition of the terrestrial archosaurian assemblage seems to be basically Pangean, but because of the fragmentary nature of the material most taxa (e.g., pterosaurs, turtles, and dinosaurs) are identified only at a high taxonomic rank, with poor paleobiogeographical significance.

Rhynchocephalians were present as early as the Triassic in Europe, North America, Madagascar and South America (Evans et al., 2001; Martínez et al., 2013). They achieved a more cosmopolitan distribution during the Early Jurassic, adding Asia, Africa and India (Kota Fm) to their range. The maxilla of rhynchocephalian identified by Flynn et al. (2006) from the Bathonian of Madagascar is actually a fragment of theropod tooth as already noted by Evans and Jones (2010).

The earliest scincomorphan lizards are present in the Bathonian of only Britain, Western Siberia and GEA 2. However, during the Late Jurassic their range was markedly broader; scincomorphans were recovered from North America, Europe, Asia and Africa (Evans, 2003). Such a range suggests a relatively cosmopolitan distribution in the Middle Jurassic.

Teleosaurid crocodyliforms were widespread marine animals and already achieved a wide Pangean distribution during the Middle Jurassic. They are mainly known in Europe (e.g., Evans and Milner, 1994; Jouve, 2009) but also in North America (Buffetaut, 1979), South America (Gasparini et al., 2000), China (Liu, 1961) and North Africa (Lapparent, 1955; Fara et al., 2002).

The first dental morphotype (i.e., slender teeth) of pterosaurs identified at GEA indicates the presence of a rhamphorhynchid taxon. This group of pterosaurs is known from various Middle Jurassic localities, both in Gondwanan and Laurasian landmasses (Barrett et al., 2008).

The terrestrial flora from the Anoual Fm, represented by wood trunks of the families Araucariaceae, Cheirolepidiaceae, Podocarpaceae, has a broad Pangean distribution (McLoughlin, 2001). According to Mojon in Haddoumi et al. (2008) and Mojon et al. (2009), the charophyte Aclistochara africana found in the lacustrine limestones of Guelb el Ahmar is also of Pangean affinities.

The wide Pangean distribution of several taxa of the fauna and flora of GEA and other sites of the Anoual Formation fits well with the general Jurassic cosmopolitanism (e.g., Ezcurra and Agnolín, 2012) and with the paleogeographical context of that time (Fig. 19).

- Taxa shared with Gondwanan sites (Table 4) 
The GEA assemblage does not include taxa restricted to the Gondwana, with the only possible exception of a dipnoan.

Although the generic assignment of many Mesozoic lungfish species based on isolated toothplates remains unclear, the dipnoan genus Arganodus seems to be present in the Gondwana from the Triassic to the Cretaceous (Soto and Perea, 2010). This genus - if not synonymous of Asiaceratodus has not been reported from post-Triassic Laurasian localities so far. Soto and Perea (2010) noted that the Jurassic lungfishes remain very poorly known in the Gondwana, with only a few occurrences of two distinct forms, i.e., Arganodus tiguidiensis and Ceratodus (or Neoceratodus) africanus. Dipnoan assemblages from the Jurassic of Laurasia are characterized by the presence of other genera such as Ferganoceratodus and Potamoceratodus (Cavin et al., 2007; Pardo et al., 2010). This clearly indicates that this peculiar Jurassic situation resulted from a vicariant event between the Gondwanan and Laurasian lungfishes during the Triassic (Cavin et al., 2007).

- Taxa shared with Laurasian sites (Table 5)

The GEA fauna displays noticeable affinities with Laurasian faunas, especially the amphibians, reptiles and mammals, i.e. the tetrapods.

The most significant taxa shared with Laurasian assemblages include the albanerpetontid and likely caudatan amphibians, anguimorph squamates, choristoderes (if confirmed), and the amphitheriid and possible dryolestidan cladotherian mammals. Several of these taxa are known in particular in the British Bathonian faunas (Table 5), which in fact are currently the best known Middle Jurassic vertebrate faunas across the world. However, it should be noted that their distribution is not restricted to Europe within Laurasia. The GEA assemblage also shows some taxonomic affinities with the Late Jurassic fauna from the Morrison Formation, USA (Chure et al., 2006; Foster and Heckert, 2011).

Nearly all albanerpetontids were recorded from Laurasia: North America (Cretaceous-Paleocene), Europe (Bathonian-Pliocene) and Asia (Late Cretaceous) (Gardner and Böhme, 2008). Outside of Laurasia, albanerpetontids were found only from the Anoual Syncline Mesozoic sites of GEA 2 and Ksar Metlili that are both located in northernmost Gondwana, close to Europe (Fig. 19).

The fossil record of the Caudata is mainly Laurasian, as early as their earliest occurrences (Middle Jurassic) (Skutchas, 2013). With the exception of GEA 2, Jurassic caudatans are known only from the Laurasian continents. The identification of a caudatan from the Bathonian of Madagascar by Flynn et al. (2006) cannot be confirmed. The remains are reported as Urodela in the text, but the single illustrated bone is labelled 'Amphibian', not 'Urodela'. This illustrated bone is supposed to be a vertebra, but if really a vertebra (which is questionable), it does not show any caudatan or even amphibian feature.

Anguimorphans make up a typically Laurasian taxon. In the Jurassic, they were present in the three Laurasian continents (Evans, 2003). The anguimorph Parviraptor from GEA 2 is known elsewhere only from the Middle and Late Jurassic and Early Cretaceous of Laurasian continents.

If confirmed, the identification of a choristodere at GEA 2 is of special interest because, up to this recovery, the group was only reported from Laurasia: Europe (Bathonian-Miocene), Asia (BathonianEocene) and North America (Late Jurassic-Paleocene) (Matsumoto and Evans, 2010). 
Atoposaurid crocodyliforms are typical components of the Late Jurassic and Cretaceous faunas of Laurasia, especially in Europe (Martin et al., 2010). The occurrence of cf. Theriosuchus at GEA may be related (vicariance or dispersal?) to the presence of Theriosuchus-like teeth in the Middle Jurassic of Western Europe (Evans and Milner, 1994; Kriwet et al., 1997; Evans et al., 2006). Together with an inderterminate form from the Early-Middle Jurassic Kota Fm (Prasad et al., 2014) and the putative atoposaurid genus Brillanceausuchus from the Early Cretaceous of Cameroon (Michard et al., 1990; Martin et al., 2010), the isolated teeth found at GEA represent the only known occurrence of atoposaurids in Gondwana.

The second dental morphotype (i.e., short robust teeth) of pterosaurs present at GEA can be found in several Laurasian taxa and occurs in some Middle-Late Jurassic microvertebrate assemblages of Western Europe (e.g., Vullo et al., 2014), whereas it is unknown in the Middle Jurassic fossil record of Gondwana.

Early cladotherian mammals, including amphitheriids and dryolestidans, are known in the Middle and Late Jurassic of Europe and Asia. Dryolestidans and dryolestids are supposed respectively of Laurasian origin and of Asian origin (Averianov et al., 2013, 2014). However, it should be noted that the possible occurrence of dryolestidans in GEA would be also among the earliest known. In Africa, dryolestidans such as Donodon are also reported only in the younger Ksar Metlili site from Anoual syncline (Sigogneau-Russell 1991b), in which they are the most frequent mammals and are represented by endemic forms. A peculiar feature of the Ksar Metlili fauna is that dryolestidans are associated with tribosphenic mammals, in contrast to Laurasian mammal assemblages. Stem zatherians such as amphitheriids are still unknown in North America. In Africa, stem zatherians were previously reported 1) in the Late Jurassic of Tanzania with Brancatherulum and Tendagurutherium (Branca, 1916; Dietrich, 1927; Heinrich 1991, 1998), and of Ethiopia (indeterminate "peramurans"; Clemens et al., 2007), and 2) in the Early Cretaceous of Cameroon (Abelodon abeli; Brunet et al., 1990) and of Morocco (Ksar Metlili) with several taxa (Table 6).

Haddoumi et al. (2008) and Mojon et al. (2009) also identified ostracods from the Middle Jurassic of Anoual Syncline with European affinities.

Previous studies also suggested Laurasian relationships of the younger Ksar Metlili local fauna (Anoual Syncline), with the occurrence of albanerpetontid and discoglossid amphibians and several mammal taxa such as triconodonts, multituberculates, "symmetrodontans", and therians (KielanJaworowska et al., 2004). The GEA assemblage supports an earlier African origin, back to at least the Middle Jurassic for some of these taxa from Ksar Metlili such as the rhynchocephalians, and possibly the dryolestidans.

- Endemic taxa and remarkable absences

No significant endemism can be detected among the vertebrates from GEA. However, this is not a definite statement because many taxa from GEA remain poorly known, as a result of the fragmentary nature of recovered microremains. Some African endemism of Ksar Metlili vertebrate fauna was previously noticed, especially within the mammal assemblage (Sigogneau-Russell et al., 1998); it is at least illustrated at generic level. 
It is worth noting that freshwater hybodont sharks, and chondrichthyans in general, are absent at GEA, whereas they are present in most of the Mesozoic continental vertebrate assemblages of Africa. In the 'Red beds' of the Anoual Syncline, sharks represented by two small hybodont taxa (Lissodus and Egertonodus) locally appear in the younger beds of the KM locality that is however better sampled.

The most remarkable taxonomic absence from the GEA fauna are the anurans that are known elsewhere in the Early to Late Jurassic of Laurasia and in the Early and Middle or Late Jurassic of South America (Roček, 2013), and the australosphenidan mammals that are known and restricted to the Gondwanan provinces since their earliest known occurrence in the Early-Middle Jurassic (e.g Madagascar and South America; see Kielan-Jaworowska et al., 2004; Flynn et al., 1999; Rougier et al., 2007). Absence of australosphenidans in GEA sites might not be significant, because of incomplete sampling and taphonomic biases, but this is less true for the younger Ksar Metlili fauna from the same Anoual Syncline, where they are also lacking. How far this reflects some (precocious) African or intra-African provincialism within Gondwana remains an open question.

- Conclusion on the paleobiographical relationships of the GEA fauna

As presently known, the GEA floral and faunal assemblage is characterized by Pangean affinities, by a significant Laurasian, and more specifically a European component, and by the possible absence of any Gondwanan taxa, including for mammals. The only possible Gondwanan taxon identified in GEA is the dipnoan genus Arganodus, assuming it is not synonymous with the Asian Asiaceratodus. However, it should be noted that the Jurassic Moroccan flora in southern Atlas includes the endemic wood Metapodocarpoxylon that is restricted to the north Gondwanan floristic province (DupéronLaudoueneix et Pons, 1985; Pons, 1988; Philippe et al., 2003). This floristic province is only at the beginning of its differentiation during the Jurassic, but it is well characterized during the early Cretaceous. It was characterized by summer-wet climatic conditions by contrast to Laurasian areas such as North America and the Iberian Peninsula showing winter-wet climatic conditions (Philippe et al., 2003).

Biogeographic relationships of the taxa recovered from GEA are obviously inferred from the known fossil record and present biotic distribution where possible. The presumed Laurasian taxa from GEA are known and well documented from various fossiliferous beds located in Laurasia, but were not recovered from Gondwanan areas (except, for some of them, in the ?Berriasian of the close Ksar Metlili locality). However, as is well known, absences of taxa may be misleading. They may be true absences (taxa never entered the considered area) or false absences (taxa were present there but have not been recovered yet), i.e. in the latter case they represent a bias of the fossil record (fossil gaps). If the absences in Gondwana result from a fossil bias, then taxa (all or part of them) from GEA that are related to taxa that were previously known only in Laurasia are actually Pangean. Therefore, we face two possibilities: 1) Middle Jurassic faunas are biased by significant fossil gaps in Gondwana, or 2) the known ranges of Middle Jurassic taxa are significant, including in Gondwana. As this issue cannot be tested in regard to available data, below we discuss palaeobiogeographic aspects in the frame of these two hypotheses.

1) The hypothesis of a major fossil bias

If the taxa supposedly of Laurasian affinities were actually Pangean, the similarities between Laurasian faunas and floras and those from the Anoual Syncline such as GEA and Ksar Metlili result 
from an inherited vicariant Pangean distribution. In that case, Middle Jurassic Pangean faunas are poorly documented in southern continents and several major taxa previously supposed Laurasian are actually primitively Pangean (caudatan and albanerpetontid amphibians, choristoderes (if confirmed), anguimorphan squamates, amphitheriid and possibly dryolestidan mammals). This hypothesis of a Middle Jurassic Pangean cosmopolitanism might be supported by the absence of well-characterized Gondwanan taxa at that time, except for some mammals such as australosphenidans; it does not conflict with the occurrence of an emerging north Gondwanan floristic province. The GEA assemblage, typified by the absence of Gondwanan taxa and the presence of "Laurasian" taxa, would be the first evidence of such a major fossil gap in southern continents.

2) The hypothesis of the absence of a significant fossil bias

If absences, or at least part of them, in Gondwana are real absences, then taxa (or part of them) regarded above as related to Laurasian forms really indicate Laurasian affinities. Therefore, their occurrence at GEA requests a dispersal between Laurasia and Gondwana. During the Middle Jurassic, two terrestrial routes were possible. At that time, the Tethys was still opening westward, and Laurasia and Gondwana remained linked west of northern Africa through the Americas (Fig. 19). Dispersal around the western Tethys Gulf was possible in this paleogeographic context, but the fossil record from Middle Jurassic of North and South America is lacking to test this dispersal route. The other possible dispersal way is a trans-Tethyan route accross the Mediterranean Tethyan Sill that was present between Europe and North Africa (Gheerbrant and Rage, 2006) (Fig. 19). In this hypothesis, the absence of Gondwanan taxa combined with the presence of Laurasian taxa in the North African sites of GEA and Ksar Meltili is remarkable.

Whatever the retained hypothesis, it should be noted that, even in a Pangean context, the close resemblance between the Bathonian faunas of GEA and Britain is striking and intriguing.

<<Fig. 19 here〉>

6.3 - Stratigraphical significance, relative age of Ksar Metlil fauna 
Table 6. Comparison of GEA and Ksar Metlili faunas, respectively Bathonian and ?Berriasian of Anoual Syncline, eastern Morocco.

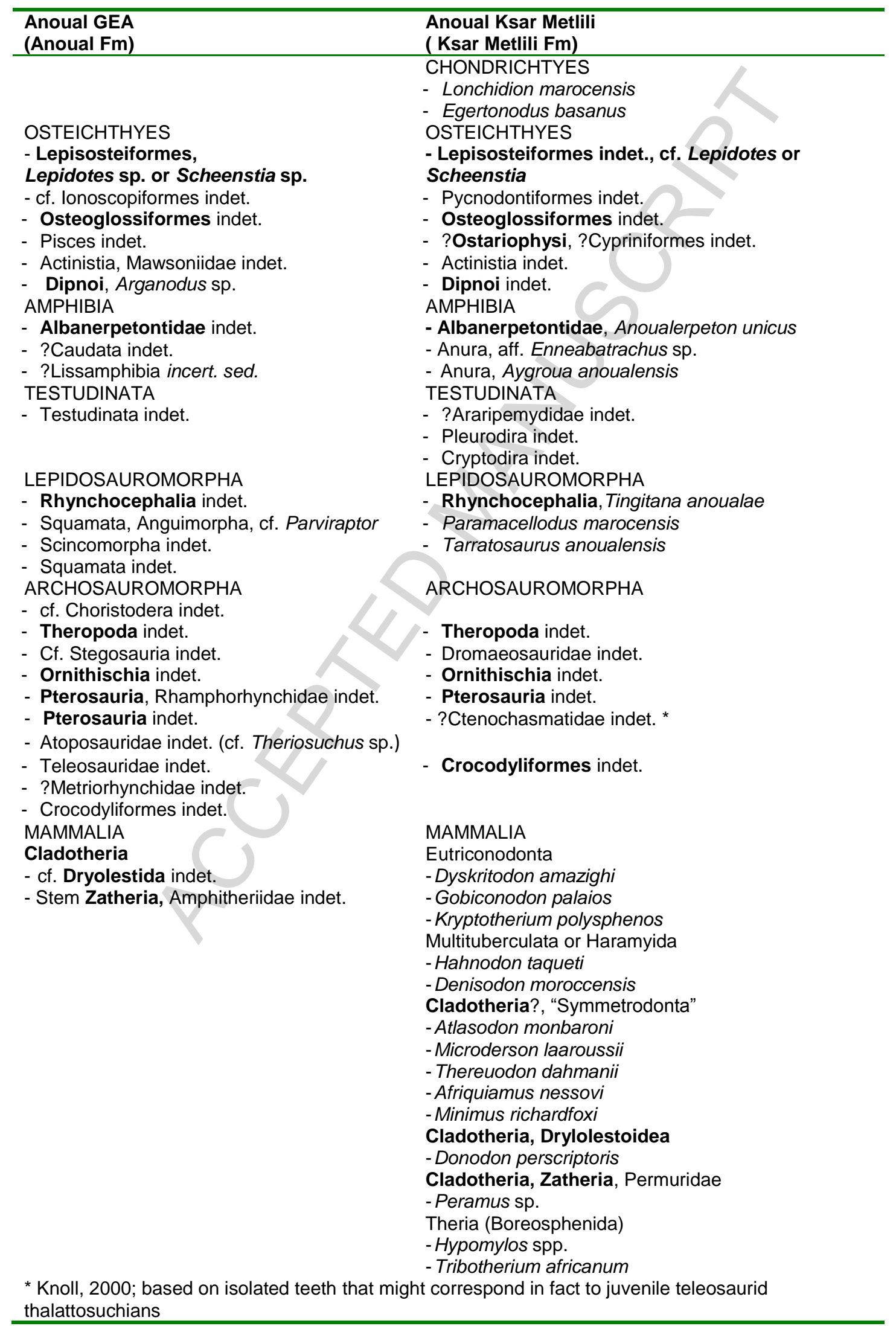


The Bathonian age of the fauna of GEA is fairly well constrained by several biostratigraphic data, including pollen, charophytes, brachiopods (Anoual Fm, upper member), ostracods, and vertebrates (see §5). The palynoflora recovered in GEA 2 indicates an age not older than the Toarcian. The vertebrate assemblage best fits that of the Bathonian of Britain. The shared presence of albanerpetontids, of the anguimorph squamate cf. Parviraptor, and of amphitheriid mammal, is strongly consistent with the Middle Jurassic (Bathonian) age.

The dating of the Ksar Metlili fauna, recovered from the red beds stratigraphically above the GEA sites (Fig. 2) in the Anoual Syncline, is comparatively much less constrained. Its Berriasian age, based mostly on the charophytes and the nannofossils, remains uncertain. Furthermore, Duffin and Sigogneau-Russell (1993) argued that the occurrence of the hybodont shark Egertonodus basanus in the KM fauna is consistent with a Berriasian age, but this specific assignment must be taken with caution and revised because of the fragmentary nature of the material and the recent description of a species very close to Egertonodus (i.e., E. duffini) in the Bathonian of England (Rees and Underwood, 2008).

The GEA microvertebrate assemblage of the Anoual Formation described in this work adds new faunal data for the discussion of the relative age of the Ksar Metlili Formation. Comparison of the GEA and KM vertebrate assemblages (Table 6 ) demonstrates primarily an overall faunal continuity between both faunas: most supra-specific taxa of GEA are found in KM fauna (which is much better documented). The most significant shared taxa of GEA and KM are the osteoglossiforms, the albanerpetodontids, the rhynchocephalians, the scincomorphans, and possibly dryolestidans. However, in the absence of more precise systematic determinations, these taxa do not help to constrain the relative age of GEA and KM faunas because of their wide stratigraphic range. The only possible significant taxon to compare stratigraphically between GEA and KM may be the rhynchocephalian. The overall morphologies of the teeth of the rhynchocephalians from GEA and KM are very close. However, as noted above, the ridges and grooves ornamentation occurs on the labial face in the GEA taxon, whereas it is on the lingual face in the rhynchocephalian from KM, i.e. Tingitana. This difference is perhaps not significant; the two taxa were perhaps closely related which would argue against a major stratigraphic gap between GEA and KM faunas.

In any case, some differences are noticed between the GEA and KM vertebrate faunas. Athough still poorly known, the presence of an amphitheriid mammal in GEA supports its older age (e.g., Middle Jurassic) with respect to KM that includes more advanced cladotherians. KM also differs noticeably from GEA by the presence of anurans, but this might be a bias of fossil documentation.

The age of the KM fauna, e.g. (Late) Jurassic vs (Early) Cretaceous, should be further tested, especially with the new faunal data issued from our 2010 new field work (work and study in progress). 


\section{Conclusions}

Three Guelb el Ahmar loci (namely GEA 1, 2, 3) from the Anoual Formation (exposed in the Anoual Syncline, Morocco) have produced one of the richest continental biotic assemblage from the Jurassic of Gondwana. With at least 29 species, the vertebrate fauna appears to be taxonomically rich and diverse. All major groups are represented, except selachians, the absence of which might be related to the lacustrine environment. Invertebrates are present, some being well represented such as ostracods. The flora is represented by trunks of trees (three families), pollen (13 species belonging to five major clades) and charophytes (Aclistochara africana).

The vertebrates are mostly documented by the microvertebrate assemblage of the locality GEA 2, that includes the first discovered mammals from the Middle Jurassic of Arabo-Africa, and among the very few mammals known from the Middle Jurassic interval worldwide.

The Guelb el Ahmar sites most noticeably yielded 1 ) several fossils that are among the earliest known representatives of various groups, along with some fossils from a few Laurasian localities: albanerpetontid and caudate amphibians, squamates (scincomorphans, anguimorphans), stem cladotherian mammals, and likely choristoderes, 2) the only known Gondwanan occurrence of choristoderes (if their presence is confirmed in GEA), the only known Mesozoic Gondwanan anguimorph and one of the very few known Gondwanan occurrences of albanerpetontid and salamanders (Caudata). The mammals from GEA are the earliest known cladotherians known in Gondwanan continents. The Guelb el Ahmar biotic assemblage supports a lacustrine freshwater depositional environment (palynoflora, charophytes, gastropods, fishes, lissamphibians, cf. choristoderes). The paleoenvironment is additionally characterized by local forests, and moderaly humid and stable climatic conditions.

The faunal assemblage of Guelb el Ahmar is characterized by the presence of Pangean and Laurasian taxa, and the quasi absence of Gondwanan taxa. Caudatan amphibians, choristoderes, anguimorphan squamates, and amphitheriid mammals were previously known only from Laurasia and, formerly, albanerpetontids were known in Gondwana only in the Ksar Metlili local fauna, from the same Anoual Syncline. The paleobiogeographical analysis of Jurassic continental biotas may be biased because of a heterogeneous fossil record with major gaps, especially in Gondwana. The presence of Laurasian taxa in the GEA assemblage may be the result of either dispersal and/or vicariance, in agreement with the Middle Jurassic paleogeographic context (Fig. 19). The absence of Gondwanan taxa in GEA, if not a bias of sampling, is difficult to explain. One proposed hypothesis is a possible intra-Gondwanan or intra-African provincialism (e.g., Philippe et al., 2003; Rauhut and Lopez-Arbarello 2008). This is supported by the Laurasian affinities of GEA fauna, especially with Eurasian Jurassic biotic assemblages, which remains original within Gondwana. Alternatively, the new GEA sites might emphasize the incompleteness of the fossil record of Gondwana such as Africa, and might support a persisting Pangean paleobiogeographic context in the Middle Jurassic. This implies that caudate and albanerpetontid amphibians, anguimorphan squamates, amphitheriid, likely choristoderes and possibly dryolestidan mammals had a Middle Jurassic Pangean distribution. 
The GEA vertebrate assemblage, that is well dated Bathonian, shows a noticeable faunal continuity with that of the younger local fauna Ksar Metlili, as illustrated for instance by the osteoglossiforms and the rhynchocephalians. This argues against a major stratigraphical gap between the two sites, and raises questions on the putative Berriasian age of Ksar Metlili fauna that needs further testing with new studies of the latter.

The GEA loci suggest that some of the Laurasian taxa of Ksar Metlili, such as the rhynchocephalians may have been inherited locally from older Bathonian African faunas. Some other taxa of the Ksar Metlili fauna such as albanerpetontids, however likely resulted from a post-Bathonian dispersal of Laurasian origin.

\section{Acknowledgements.}

Fieldwork in the Anoual syncline was supported by the National Geographic Society CRE GRANT \#8706-09 (PI: E. Gheerbrant). We thank F. Goussard (CR2P, MNHN) and M. Garcia Sanz (MNHN) for help with the CT scan study and 3 D modelling of the specimens GEA 2-1, GEA 2-2.

Photographs (pollen, vertebrates) were made by L. Cazes (CR2P, MNHN). We thank V. Prugneaux, J. Esnault, and J. Marchand (SAGA) for the long and laborious task of the sorting of the sediment samples. We are grateful to C.J. Duffin and E.V. Popov for helpful discussions about myriacanthids. We thank P. Skutchas for various informations on salamanders. We thank F. de Lapparent de Broin for help with the study of the turtles. We thank the two anonymous reviewers and the Associate Editor of Gondwana Research for their corrections and their useful comments which helped to improve the manuscript. 


\section{References}

Allain, R., Aquesbi, N., 2008. Anatomy and phylogenetic relationships of Tazoudasaurus naimi (Dinosauria, Sauropoda) from the late Early Jurassic of Morocco. Geodiversitas 30, 345-424.

Allain, R., Aquesbi, N., Dejax, J., Meyer, C., Monbaron, M., Montenat, C., Richir, P., Rochdy, M., Russell, D.A., Taquet, P., 2004. A basal sauropod dinosaur from the Early Jurassic of Morocco. Comptes Rendus Palevol 3, 199-208.

Anquetin, J., Barrett, P.M., Jones, M.E.H., Moore-Fay, S., Evans, S.E., 2009. A new stem turtle from the Middle Jurassic of Scotland: new insights into the evolution and palaeoecology of basal turtles. Proceedings of the Royal Society B 276, 879-886.

Attims, Y., 1965. Etude anatomique et paléogéographique de quelques bois jurassiques du Maroc. Notes du Service géologique du Maroc 24, 33-52.

Averianov, A.O., Martin, T., Lopatin, A.V., 2013. A new phylogeny for basal Trechnotheria and Cladotheria and affinities of South American endemic Late Cretaceous mammals. Naturwissenschaften 100, 311-326.

Averianov, A.O., Martin, T., Lopatin, A.V., 2014. The oldest dryolestid mammal from the Middle Jurassic of Siberia. Journal of Vertebrate Paleontology 34, 924-931

Barrett, P., Butler, R., Edwards, N.P., Milner, A.R., 2008. Pterosaur distribution in time and space: an atlas. Zitteliana B28, 61-107.

Barrier, E., Vrielynck, B., 2008. Palaeotectonic maps of the Middle East: Tectono-sedimentaryPalinspatic maps from Late Norian to Pliocene: Paris, Commission for the Geological Map of the World (CGMW)/UNESCO (http://www.ccgm.org) Atlas of 14 maps, scale 1:18, 500,000.

Barron, E., Ureta, S., Goy, A., Lassaletta, L. 2010. Palynology of the Toarcian-Aalenian global boundary stratotype section and point (GGGP) at Fuentelsaz (Lower-Middle Jurassic, Iberian Range, Spain). Review of Palaeobotany and Palynology 162, 11-28.

Batten, D.J., 1999. Small Palynomorphs. In: Jones T.P., Rowe N.P. (Eds), Fossil Plants and Spores: Modern Techniques. London, Geological Society of London, 15-19.

Boureau, E., 1951. Etude paléoxylologique de l'Afrique du Nord: présence du Dadoxylon (Araucarioxylon) teixeirae Boureau dans le Haut-Atlas du Maroc. Notes du Service géologique du Maroc 4, 121-133.

Boureau, E., 1957. Sur le Protopodocarpoxylon teixeirae Boureau. Affinités. Répartition géographique. Signification stratigraphique. Communications du Service géologique du Portugal 38, 423-430.

Branca, W., 1916. Ein Saugetier?-Unterkiefer aus den Tendaguru-Schichten. Arch. Biont. 4: 137-140.

Bucefalo Palliani, R., 1997. Toarcian sporomorph assemblages from the Umbria-Marche basin, central Italy. Palynology 21, 105-121. 
Brunet, M., Coppens, Y., Dejax, J., Flynn, L., Heintz, E., Hell, J., Jacobs, L., Jehenne, Y., Mouchelin, G., Pilbeam, D., Sudre, J., 1990. Nouveaux mammifères du Crétacé inférieur de Cameroun, Afrique de l'Ouest. Comptes Rendus de l'Académie des sciences série II 310, 1139-1146.

Buffetaut, E., 1979. Jurassic marine crocodilians (Mesosuchia: Teleosauridae) from Central Oregon: first record in North America. Journal of Paleontology 53, 210-215.

Butler, P.M., Clemens, W.A., 2001. Dental morphology of the Jurassic holotherian mammal Amphitherium, with a discussion of the evolution of mammalian post-canine dental formulae. Palaeontology 44, 1-20.

Caïa, J., 1972. Carte géologique et minéralisations des régions situées au Sud et à l'Est de la moyenne Moulouya (Haut Atlas oriental, régions des Plis marginaux, Rekkame). Notes et Mémoires du Service géologique du Maroc 233.

Carroll, R.L., Currie, P.J., 1975. Microsaurs as possible apodan ancestors. Zoological Journal of the Linnean Society 57, 229-247.

Carvalho, M.S.S. de, Maisey, J.G., 2008. New occurrence of Mawsonia (Sarcopterygii: Actinistia) from the Early Cretaceous of Sanfranciscana Basin, Minas Gerais, southeastern Brazil. In: Cavin L., Longbottom A., Richter, M. (Eds.), Fishes and the Break-up of Pangaea. Geological Society Special Publication 295, London, 109-144.

Cavin, L., Forey, P.L., 2004. New mawsoniid coelacanth (Sarcopterygii: Actinistia) remains from the Cretaceous of the Kem Kem beds, Southern Morocco. In: Arratia G., Tintori A., Richter M. (Eds.), Mesozoic Fishes 3 - Systematics, Paleoenvironments and Biodiversity. Verlag Friedrich Pfeil, München, 492-506.

Cavin, L., Suteethorn, V., Buffetaut, E., Tong, H. 2007. A new Thai Mesozoic lungfish (Sarcopterygii, Dipnoi) with an insight into post-Palaeozoic dipnoan evolution. Zoological Journal of the Linnean Society 149, 141-177.

Charrière, A., 1992. Discontinuités entre les "Couches rouges" du Jurassique moyen et du Crétacé inférieur dans le Moyen-Atlas (Maroc). Comptes Rendus de l'Académie des Sciences 315, 13891396.

Charrière, A., 1996. Contexte paléogéographique et paléotectonique de la formation des bassins crétacés du Moyen-Atlas (Maroc) à la lumière des données stratigraphiques récentes. Bulletin de la Société géologique de France 167, 617-626.

Charrière, A., Dépêche, F., Feist, M., Grambast-Fessard, N., Jaffrenzo, M., Peybernes, B., Ramalho, M., 1994. Microfaunes, micro-flores et paléoenvironnements successifs dans la formation d'El Mers (Bathonien-?Callovien) du synclinal de Skoura (Moyen-Atlas, Maroc). Geobios, 27, fasc. 2, 157-174.

Charrière, A., Haddoumi, H., Mojon, P.-O., 2005. Découverte du Jurassique supérieur et d'un niveau marin du Barrémien dans les "couches rouges" continentales du Haut Atlas central marocain: implications paléo-géographiques et structurales. Comptes Rendus Palevol, Paris, t. 4, fasc. 5, 385-394. 
Choubert, G., Diouri, M., 1969. Bois fossiles du Maroc. Introduction stratigraphique. Notes et Mémoires du Service géologique du Maroc 210, 9-18.

Choubert, G., Faure-Muret, A., 1960-1962. Évolution du domaine atlasique marocain depuis les temps paléozoïques. In: Livre à la mémoire du Professeur Paul FALLOT. Mémoire hors-série de la Société géologique de France 1, 447-527.

Chure, D.J., Litwin, R., Hasiotis, S.T., Evanoff E., Carpenter, K., 2006. The fauna and flora of the Morrison Formation: 2006. New Mexico Museum of Natural History and Science Bulletin 36, 233-249.

Clemens, W.A., Goodwin, M.B., Hutchison, J.H., Schaff, C.R., Wood, C.B., Colbert, M.W., 2007. First record of a Jurassic mammal (?"Peramura”) from Ethiopia. Acta Palaeontologica Polonica 52, 433-439.

Cúneo, R., Ramezani, J., Scasso R., Pol, D., Escapa, I., Zavattieri, A. M., Bowring, S. A. (2013). Highprecision $\mathrm{U}-\mathrm{Pb}$ geochronology and a new chronostratigraphy for the Cañadón Asfalto Basin, Chubut, central Patagonia: Implications for terrestrial faunal and floral evolution in Jurassic. Gondwana Research 24, 1267-1275.

Davis, B.M., 2011. Evolution of the tribosphenic molar pattern in early mammals, with comments on the "dual-origin" hypothesis. Journal of Mammalian Evolution 18,227-244.

Dehbozorgi, A., Sajjadi, F. , Hashemi, H., 2013. Middle Jurassic palynomorphs of the Dalichai Formation, central Aborz Ranges, northeastern Iran: paleoecological inférences. Sciences China Earth Sciences 56, 2107-2114.

Dietrich, W. O. 1927. Brancatherulum n. g., ein Proplacentalier aus dem obersten Jura des Tendaguru in Deutsch-Ostafrika. Centralbl. Min. Geol. Palaont. 1927 (B), 423-426.

du Dresnay, R., 1956. Contribution à l'étude de la série détritique jurassico-crétacée dans le Haut Atlas oriental. Notes du Service géologique du Maroc 14, 9-32.

du Dresnay, R., 1969. Bois fossiles du Maroc. Discussions stratigraphiques sur les conditions de gisements de bois fossiles mésozoïques du Maroc, étudiés par Mlles Y. Attims, F. Cremier et F. Gazeau. Notes et Mémoires du Service géologique du Maroc 210, 121-179.

du Dresnay, R., 1976. Carte géologique du Haut Atlas d'Anoual - Bou Anane (Haut Atlas oriental). Échelle 1/200 000. Notes et Mémoires du Service géologique du Maroc 246.

du Dresnay, R., 1979. Sédiments jurassiques du domaine des chaînes atlasiques du Maroc. In: Symposium "Sédimentation du Jurassique W européen", Paris (1977).- Association des Sédimentologistes français, Publication spéciale 1, 345-365.

Duffin, C.J., 1981. The fin spine of a new holocephalan from the Lower Jurassic of Lyme Regis, Dorset, England. Geobios 14, 469-475.

Duffin, C.J., 1983. Holocephalans in the Staatliches Museum für Naturkunde in Stuttgart. 1. Myriacanthoids and squalorajoids. Stuttgarter Beiträge zur Naturkunde, Serie B 97, 1-41. 
Duffin, C.J. \& Sigogneau-Russell, D. 1993. Fossil Shark Teeth from the Early Cretaceous of Anoual, Morocco. Belgian Geological Survey, Professional Paper 264, 175-190.

Dupéron-Laudoueneix, M., Pons, D., 1985. Nouvelle étude du Mesembrioxylon libanoticum Edwards (Conifère du Mésozoïque supérieur); intérêts paléogéographique, biostratigraphique et paléoclimatique. Giornale Botanico Italiano 119, 151-166.

Erdtman, G., 1943. An introduction to pollen analysis. Waltham, MA: Chronica Botanica Company.

Evans, S.E., 1990. The skull of Cteniogenys, a choristodere (Reptilia: Archosauromorpha) from the Middle Jurassic of Oxfordshire. Zoological Journal of the Linnean Society 99, 205-237.

Evans, S.E., 1991. The postcranial skeleton of the choristodere Cteniogenys (Reptilia: Diapsida) from the Middle Jurassic of England. Geobios 24, 187-199.

Evans, S.E., 1994. A new anguimorph lizard from the Jurassic and Lower Cretaceous of England. Palaeontology 37, 33-49.

Evans, S.E., 1996. Parviraptor (Squamata: Anguimorpha) and other lizards from the Morrison Formation at Fruita, Colorado. In: Morales, M. (Ed.), The Continental Jurassic. Museum of Northen Arizona Bulletin 60, 243-248.

Evans, S.E., 1998. Crown group lizards (Reptilia, Squamata) from the Middle Jurassic of the British Isles. Palaeontographica A 250, 123-154.

Evans, S.E., 2003. At the feet of the dinosaurs: the early history and radiation of lizards. Biological Review 78, 513-551.

Evans, S.E., Barrett, P.M., Hilton, J., Butler, R.J., Jones, M.E.H., Liang, M.M., Parish, J.C., Rayfield, E.J., Sigogneau-Russell, D., Underwood, C.J., 2006. The Middle Jurassic vertebrate assemblage of Skye, Scotland. In: Barrett, P.M., Evans, S.E. (Eds.), Ninth international symposium on Mesozoic terrestrial ecosystems and biota. Natural History Museum Publications, London, 36-39.

Evans S.E., Jones M.E.H., 2010. The origin, early history and diversification of lepidosauromorph reptiles. In: Bandyopadhyay S. (Ed.), New aspects of Mesozoic biodiversity. Lecture Notes in Earth Sciences 132, 27-44.

Evans, S.E., Milner, A.R., 1994. Middle Jurassic microvertebrate assemblages from the British Isles. In: Fraser, N.C., Sues, H.-D. (Eds.), In the Shadow of the Dinosaurs. Cambridge University Press, Cambridge, 303-321.

Evans, S.E., Milner, A.R., Mussett, F., 1988. The earliest known salamanders (Amphibia, Caudata): A record from the Middle Jurassic of England. Geobios 21, 539-552.

Evans, S.E., Milner, A.R., Werner, C., 1996. Sirenid salamanders and a gymnophionan amphibian from the Cretaceous of the Sudan. Palaeontology 39, 77-95.

Evans, S.E., Prasad, G.V.R., Manhas, B.K., 2001. Rhynchocephalians (Diapsida: Lepidosauria) from the Jurassic Kota Formation of India. Zoological Journal of the Linnean Society 133, 309-334. 
Evans, S.E., Searle, B., 2002. Lepidosaurian reptiles from the Purbeck limestone Group of Dorset, southern England. In: Milner A.R., Batten D.J. (Eds), Life and environments in Purbeck Times. Special Papers in Palaeontology 68, 145-159.

Evans, S.E., Sigogneau-Russell, D., 1997. New sphenodontians (Diapsida: Lepidosauria: Rhynchocephalia) from the Early Cretaceous of North Africa. Journal of Vertebrate Paleontology 17, 45-51.

Evans, S.E., Waldman, M., 1996. Small reptiles and amphibians from the Middle Jurassic of Skye, Scotland. In, Morales M. (Ed.), The continental Jurassic. Museum of Northen Arizona Bulletin, 60, 219-226.

Ezcurra, M. D., Agnolín, F.L., 2012. A new global palaeobiogeographical model for the late Mesozoic and early Tertiary. Systematic Biology 61, 553-566.

Fara, E, Ouaja, M., Buffetaut, E., Srarfi, D., 2002. First occurrence of thalattosuchian crocodiles in the Middle and Upper Jurassic of Tunisia. Neues Jahrbuch für Geologie und Paläontologie, Monatshefte 2002, 465-476.

Fenton, J.P.G., 1984. Palynological investigation of the Triassic-Middle Jurassic sequences at Deep Sea drilling Project Leg 79, sites 545, 546, and hole 547B, of central Morocco. DSDP Initial Report, 79, Part VI, 715-718.

Flynn, J.J., Parrish, J.M., Rakotosamimanana, B., Simpson, W.F., Wyss, A.R., 1999. A Middle Jurassic mammal from Madagascar. Nature 401, 57-60.

Flynn, J.J., Fox, S.R., Parrish, J.M., Ranivoharimanana, L., Wyss A.R., 2006. Assessing diversity and paleoecology of a Middle Jurassic microvertebrate assemblage from Madagascar. New Mexico Museum of Natural History and Science Bulletin 37, 476-489.

Friedman, M., Dornburg, A., Near, T., 2014. Morphological clocks close the gap between ages of teleost fishes estimated from molecular clocks and the fossil record. Journal of Vertebrate Paleontology, Program and Abstracts, 2014, 133.

Foster, J.R., Heckert, A.B., 2011. Ichthyoliths and other microvertebrate remains from the Morrison Formation (Upper Jurassic) of northeastern Wyoming: A screen-washed sample indicates a significant aquatic component. Palaeogeography, Palaeoclimatology, Palaeoecology 305, 264279.

Fuente, M. de la, Lapparent de Broin, F., 1997. An Araripemys-like decorated pleurodire turtle in the Paleocene of northwestern Argentine. Geobios 30, 235-242.

Gao, K.Q., Chen J., Jia, J., 2013. Taxonomic diversity, stratigraphic range, and exceptional preservation of Juro-Cretaceous salamanders from northern China. Canadian Journal of Earth Sciences 50, 255-267.

Gardner, J.D., 2002. Monophyly and intra-generic relationships of Albanerpeton (Lissamphibia; Albanerpetontidae). Journal of Vertebrate Paleontology 22, 12-22. 
Gardner, J.D., Böhme, M., 2008. Review of the Albanerpetontidae (Lissamphibia), with comments on the paleoecological preferences of European Tertiary albanerpetontids. In, Sankey J.T. and Baszio S. (Eds), Vertebrate microfossil assemblages. Indiana University Press, Bloomington and Indianapolis, 178-218.

Gasparini, Z., Vignaud, P., Chong, G., 2000. The Jurassic Thalattosuchia (Crocodyliformes) of Chile: a paleobiogeographic approach. Bulletin de la Société Géologique de France 171, 657-664.

Gauthier, J.A., Kearney, K., Maisano, J.A., Rieppel, O., Behlke, A.D.B., 2012. Assembling the squamate tree of life: Perspectives from the phenotype and the fossil record. Bulletin of the Peabody Museum of Natural History 53, 3-308.

Gayet, M., Brito, P.M., 1989. Ichthyofaune nouvelle du Crétacé supérieur du Groupe Bauru (Etats de Sâo Paulo et Minas Gerais, Brésil). Geobios 22, 841-847.

Gayet, M., Meunier, F.J., 1983. Ecailles actuelles et fossiles d'Ostéoglossiformes (Pisces, Teleostei). Comptes Rendus de l'Académie des sciences, Paris, Série II, 297, 867-870.

Gazeau, F., 1969. Sur la présence de Dadoxylon (Araucarioxylon), aff. sahariense Veillet-Bartoszewska dans le Mésozoïque du Moyen Atlas. Notes et Mémoires du Service Géologique du Maroc 210, 95-102.

Gheerbrant, E., Rage J.-C., 2006. Paleobiogeography of Africa: How distinct from Gondwana and Laurasia? Palaeogeography, Palaeoclimatology, Palaeoecology 241,224-246.

Goodwin, M.B., Clemens, W.A., Hutchison, J.H., Wood, C.B, Zavada, M.S., Kemp, A., Duffin, C.J., Schaff, C.R., 1999. Mesozoic continental vertebrates with associated palynostratigraphic dates from the northwestern Ethiopian plateau. Journal of Vertebrate Paleontology 19,728-741.

Greven, H., Clemen, G., 1980. Morphological studies on the mouth cavity of urodeles. VI. The teeth of the upper jaw and the palate in Andrias davidianus (Blanchard) and A. japonicus (Temminck) (Cryptobranchidae: Amphibia). Amphibia-Reptilia, 1, 49-59.

Guy-Ohlson, D., 1986. Jurassic palynology of the Vilhelmfält bore N 1, Scania, Sweden ToarcianAalenian. Section of Palaeobotany, Swedish Museum of Natural History, 1-127.

Haddoumi, H., 1998. Les formations détritiques «couches rouges» (Bathonien et Crétacé inférieur) de la région d'Anoual (Haut Atlas oriental, Maroc): sédimentologie, stratigraphie et paléogéographie. Thèse d'Etat Université Mohammed 1er, 1-229 (Oujda, unpublished).

Haddoumi, H., Almeras, Y., Bodergat, A.M., Charriere, A., Mangold, C., Benshili, K., 1998. Âges et environnements des Couches rouges d'Anoual (Jurassique moyen et Crétacé inférieur, Haut Atlas oriental, Maroc). Comptes Rendus de l'Académie des sciences, Paris, série Ila, 327, 127133.

Haddoumi, H., Charriere, A., Andreu, B., Mojon, P.-O., 2008 Les dépôts continentaux du Jurassique moyen au Crétacé inférieur dans le Haut Atlas oriental (Maroc): paléoenvironnements successifs et signification paléogéographique. Carnets de Géologie/Notebooks on Geology, Brest, Article 2008/06 (CG2008_A06), 1-29. 
Haddoumi, H., Charrière, A., Mojon, P.O., 2010. Stratigraphie et sédimentologie des "Couches rouges» continentales du Jurassique-Crétacé du Haut Atlas central (Maroc): implications paléogéographiques et géodynamiques. Geobios 43, 433-451.

Heinrich, W. D. 1991. Über Brancatherulum tendagurense Dietrich, 1927 (Mammalia, Eupantotheria) aus dem Oberjura von Tendaguru, Tansania. Mitt. Zool. Mus. Berlin 67:97-104.

Heinrich, W.-D. 1998. Late Jurassic mammals from Tendagaru, Tanzania, East Africa. Journal of Mammalian Evolution 5, 269-289.

Heinrich, W.-D., 1999. First haramiyid (Mammalia, Allotheria) from the Mesozoic of Gondwana. Mitteilungen aus dem Museum für Naturkunde in Berlin, Geowissenschaftliche 2, 159-170.

Heinrich, W.-D., 2001. The German-Tanzanian Tendaguru Expedition 2000. Mitteilungen aus dem Museum für Naturkunde in Berlin, Geowissenschaftliche 4, 223-237.

Hoelstad, T., 1985. Palynology of the uppermost Lower to Middle Jurassic strata on Bornholm, Denmark. Bulletin of the geological Society of Denmark 34, 111-132.

Hussakof, L., 1917. Fossil fishes collected by the American Museum Congo expedition. Bulletin of the American Museum of Natural History 37, 761-767.

Hutchinson, M.N., Skinner, A., Lee,M.S.Y., 2012. Tikiguania and the antiquity of squamate reptiles (lizards and snakes). Biology Letters 8, 665-669.

Jenkins, F.A., Walsh, D.M., Carroll, R.L., 2007. Anatomy of Eocaecilia micropodia, a limbed caecilian of the Early Jurassic. Bulletin of the Museum of Comparative Zoology 158, 285-366.

Jenny, J., Le Marrec, A., Monbaron, M., 1981. Les Couches rouges du Jurassique moyen du Haut Atlas central (Maroc): corrélations lithostratigraphiques, éléments de datations et cadre tectonosédimentaire. Bulletin de la Société géologique de France 23, 627-639.

Jouve, S., 2009. The skull of Teleosaurus cadomensis (Crocodylomorpha; Thalattosuchia), and phylogenetic analysis of Thalattosuchia. Journal of Vertebrate Paleontology 29, 88-102

Kemp, A., 1998. Skull structure in post-Paleozoic lungfish. Journal of Vertebrate Paleontology 18, $43-$ 63.

Kielan-Jaworowska, Z., Cifelli, R.L., Luo, Z.-X., 2004. Mammals from the age of dinosaurs: origins, evolution, and structure. Columbia University Press, New York, 1-630.

Kilian, C. ,1931. Des principaux complexes continentaux du Sahara. Comptes Rendus de la Société gologique de France 9, 109-111.

Knoll, F., 2000. Pterosaurs from the Lower Cretaceous (?Berriasian) of Anoual, Morocco. Annales de Paléontologie 86, 157-164.

Knoll, F., 2005. The tetrapod fauna of the Upper Elliot and Clarens formations in the main Karoo Basin (South Africa and Lesotho). Bulletin de la Société Géologique de France 176, 81-91. 
Knoll F., Ruiz-Omeñaca J.I. 2009. Theropod teeth from the basalmost Cretaceous of Anoual (Morocco) and their palaeobiogeographical significance. Geological Magazine 146, 602-616.

Kosma, R., 2004. The dentitions of recent and fossil scincomorphan lizards (Lacertilia, Squamata) systematics, functional morphology, paleoecology. Ph. D dissertation, Fachbereich Geowissenschaften und Geographie, Universität Hannover, 1-187.

Kriwet, J., Rauhut, O.W.M., Gloy, U., 1997. Microvertebrate remains (Pisces, Archosauria) from the Middle Jurassic (Bathonian) of southern France. Neues Jahrbuch für Geologie und Paläontologie, Abhandlungen 206, 1-28.

Kumazawa, Y., Nishida, M., 2000. Molecular phylogeny of Osteoglossoids: a new model for Gondwanian origin and plate tectonic transportation of the Asian arowana. Molecular Biology and Evolution 17, 1869-1878.

Lapparent, A.F. de, 1955. Etude paléontologique des vertébrés du Jurassique d’El Mers (Moyen Atlas). Notes et Mémoires du Service Géologique du Maroc 124, 1-36.

Lauprasert, K., Laojumpon, C., Saenphala, W., Cuny, G., Thirakhupt, K., Suteethorn, V., 2011. Atoposaurid crocodyliforms from the Khorat Group of Thailand: first record of Theriosuchus from Southeast Asia. Paläontologische Zeitschrift 85, 37-47.

Leriche, M., 1911. Les poissons des couches du Lualaba (Congo Belge). Revue Zoologique Africaine 1, 190-197.

Leriche, M., 1920. Notes sur la paléontologie du Congo. Revue Zoologique Africaine 8, 67-86.

Liu, H.-T., 1961. The discovery of Teleosaurus in China. Vertebrata Palasiatica 1, 69-71.

Lopatin, A.V, Averianov, A.O. 2007. The earliest Asiatic pretribosphenic mammal (Cladotheria, Amphitheriidae) from the Middle Jurassic of Siberia. Doklady Biological Sciences 417,432-434;

López-Arbarello, A., Rauhut, O.W.M., Moser, K., 2008. Jurassic fishes of Gondwana. Revista de la Asociación Geológica Argentina 63, 586-612.

López-Arbarello, A., 2012. Phylogenetic interrelationships of ginglymodian fishes (Actinopterygii: Neopterygii). PLOS ONE 7, e39370, 1-44.

Lü, J., Bo, X., 2011. A new rhamphorhynchid pterosaur (Pterosauria) from the Middle Jurassic Tiaojishan Formation of western Liaoning, China. Acta Geologica Sinica 85, 977-983.

Lü, J., Xu, L., Chang, H., Zhang, X., 2011. A new darwinopterid pterosaur from the Middle Jurassic of western Liaoning, northeastern China and its ecological implications. Acta Geologica Sinica 85, 507-514.

Martin, M., 1979. Arganodus atlantis et Ceratodus arganensis, deux nouveaux dipneustes du Trias supérieur continental marocain. Comptes rendus hebdomadaires des séances de l'Académie des sciences, Paris, Série D 289, 89-92. 
Martin, M., 1984. Révision des arganodontidés et des néoceratodontidés (Dipnoi, Ceratodontiformes) du Crétacé africain. Neues Jahrbuch für Geologie und Paläontologie, Abhandlungen 169, 225-260.

Martin, J.E., Rabi, M., Csiki, Z., 2010. Survival of Theriosuchus (Mesoeucrocodylia: Atoposauridae) in a Late Cretaceous archipelago: a new species from the Maastrichtian of Romania. Naturwissenschaften 97, 845-854.

Martin J.E., Rabi M., Csiki-Sava Z. 2014. Cranial morphology of Theriosuchus sympiestodon (Mesoeucrocodylia, Atoposauridae) and the widespread occurrence of Theriosuchus in the Late Cretaceous of Europe. Journal of Paleontology 88, 444-456.

Martin, T., 1997. Tooth replacement in Late Jurassic Dryolestidae (Eupantotheria, Mammalia). J Mamm Evol 4, 1-18

Martin, T ., (2002). New stem-line representatives of Zatheria (Mammalia) from the Late Jurassic of Portugal. Journal of Vertebrate Paleontology 22,332-348

Martin, T., Rauhut, O.W.M., 2005. Mandible and dentition of Asfaltomylos patagonicus (Australosphenida, Mammalia) and the evolution of tribosphenic teeth. Journal of Vertebrate Paleontology 25, 414-423.

Martínez R.N., Apaldetti C., Colombi C.E., Praderio A., Fernandez E., Malnis P.S., Correa G.A., Abelin D., Alcober O., 2013. A new sphenodontian (Lepidosauria: Rhynchocephalia) from the Late Triassic of Argentina and the early origin of the herbivore opisthodontians. Proceedings of the Royal Society B 280, 20132057.

Matsumoto, R., Evans, S.E., 2010. Choristoderes and the freshwater assemblages of Laurasia. Journal of Iberian Geology 36, 253-274.

Matsumoto R., Buffetaut E., Escuillié F., Hervet S., Evans S.E., 2013. New material of the choristodere Lazarussuchus (Diapsida, Choristodera) from the Paleocene of France. Journal of Vertebrate Paleontology 33, 319-339.

McLoughlin, S., 2001. The breakup history of Gondwana and its impact on pre-Cenozoic floristic provincialism. Australian Journal of Botany 49, 271-300.

Metcalf, S.J., Walker, R.J., 1994. A new Bathonian microvertebrate locality in the English Midlands. In: Fraser, N.C, Sues, H.-D. (Eds.), In the Shadow of the Dinosaurs. Cambridge University Press, Cambridge, 322-331.

Metcalf, S.J., Vaughan, R.F., Benton, M.J., Cole, J., Simms, M.J., Dartnall, D.L., 1992. A new Bathonian (Middle Jurassic) microvertebrate site, within the Chipping Norton Limestone Formation at Hornsleasow Quarry, Gloucestershire. Proceedings of the Geologists' Association 103, 321-342.

Michard, J.-G., Broin, F. de, Brunet, M., Hell, J., 1990. Le plus ancien crocodilien néosuchien spécialisé à caractères « eusuchiens » du continent africain (Crétacé inférieur, Cameroun). Comptes Rendus de l'Académie des Sciences, série II, 311, 365-371. 
Michard, A., Saddiqi, O., Chalouan, A, Frizon de Lamotte, D., 2008. Continental Evolution: The Geology of Morocco. Structure, Sratigraphy, and Tectonics of Africa- Atlantic- Mediterranean Triple Junction. Springer-Verlag Berlin Heidelberg, 1-424.

Miguel, R., Gallo, V., Morrone, J.J., 2014. Distributional patterns of † Mawsoniidae (Sarcopterygii: Actinistia). An Acad Bras Ciênc 86, 159-170.

Milner, A.R., 2004. The turtle of the Purbeck Limestone Group of Dorset, southern England. Palaeontology 47, 1441-1467.

Milner, S.C., Duncan, A.R., Ewart, A., Marsh, J.S., 1994. Promotion of the Etendeka Formation to Group status: A new integrated stratigraphy. Communications of the Geological Survey of Namibia 9, 5-11.

Mojon, P.O., Haddoumi, H., Charrière, A., 2009. Nouvelles données sur les Charophytes et Ostracodes du Jurassique moyen-supérieur-Crétacé inférieur de l'Atlas marocain. Carnets de Géologie /Notebooks on Geology, Brest, Mém. 2009/03 (CG2009_M03 1-39).

Monbaron, M., Taquet, P., 1981. Découverte du squelette complet d'un grand Cétiosaure (Dinosaure Sauropode) dans le bassin jurassique moyen de Tilougguit (Haut-Atlas central, Maroc). Comptes Rendus de l'Académie des Sciences, Paris 292, 243-246.

Monbaron, M., 1988. Un serpent de mer: le problème de la datation des "Couches rouges" du Haut Atlas marocain. Le point de la situation. Actes de la Société jurassienne d'émulation, Porrentruy, 73-92.

Monbaron, M., Russell, D.A., Taquet P., 1999. Atlasaurus imelakei, a brachiosaurid-like sauropod from Middle Jurassic of Morocco. Comptes rendus de l'Académie des sciences Série II 329, 519-526.

Owen, R., 1879. Monograph on the fossil reptilia of the Wealden and Purbeck Formations. Supplement IX, Crocodilia (Goniopholis, Brachydectes, Nannosuchus, Theriosuchus and Nuthetes). Monographs of the Palaeontographical Society 33, 1-19.

Pardo, J.D., Huttenlocker, A.K., Small, B.J., Gorman II, M.A., 2010. The cranial morphology of a new genus of lungfish (Osteichthyes: Dipnoi) from the Upper Jurassic Morrison Formation of North America. Journal of Vertebrate Paleontology 30, 1352-1359.

Parmar, V., Prasad, G.V.R., Kumar, D., 2013. The first multituberculate mammal from India. Naturwissenschaften $100,515-523$

Pérez-García A., Scheyer T.M., Murelaga X., 2013. The turtles from the uppermost Jurassic and Early Cretaceous of Galve (Iberian Range, Spain): Anatomical, systematic, biostratographic and palaeobiogeographical implications. Cretaceous Research 44, 64-82.

Philippe, M., Bamford, M., McLoughlin, S., Alves, L.S.R., Falcon-Lang, H.J., Gnaedinger, S., Ottone, E.G., Pole, M., Rajanikanth, A., Shoemaker, R.E., Torres, T., Zamuner, A., 2004. Biogeographic analysis of Jurassic-Early Cretaceous wood assemblages from Gondwana. Review of Palaeobotany and Palynology 129, 141-173. 
Philippe, M., Cuny, G., Bamford, M., Jaillard, E., Barale, G., Gomez, B., Ouaja, M., Thévenard, F., Thiébaut, M., Von Sengbusch, P., 2003. The palaeoxylological record of Metapodocarpoxylon libanoticum (Edwards) Dupéron-Laudoueneix et Pons and the Gondwana Late Jurassic-Early Cretaceous continental biogeography. Journal of Biogeography, 30, 389-400.

Pierce, S.E., Benton, M.J., 2006. Pelagosaurus typus Bronn, 1841 (Mesoeucrocodylia: Thalattosuchia) from the Upper Lias (Toarcian, Lower Jurassic) of Somersert, England. Journal of Vertebrate Paleontology 26, 621-635.

Pons, D., 1988. Le Mésozoïque de Colombie macroflores et microflores. Cahiers de Paléontologie, CNRS, Paris, 1-168.

Prasad, G.V.R., 1987. Squamules of osteoglossid fish from the Intertrappean Beds of Pargi, Andhra Pradesh. Current Science 56, 1270-1272.

Prasad, G.V.R., Lapparent de Broin, F. de, 2002. Late Cretaceous crocodile remains from Naskal (India): comparisons and biogeographic affinities. Annales de Paléontologie 88, $19-71$.

Prasad, G.V.R, Manhas, B.K., 2002. Triconodont mammals from the Jurassic Kota Formation of India. Geodiversitas 24, 445-464

Prasad, G.V.R., Manhas, B.K., 2007. A New docodont mammal from the Jurassic Kota Formation of India. Palaeontologia Electronica $107 \mathrm{~A}, 1-11$.

Prasad, G.V.R., Parmar, D., Kumar, D., 2014. Recent vertebrate fossil discoveries from the Jurassic Kota Formation of India. Journal of Vertebrate Paleontology, Program and Abstracts, 2014, 208.

Rage, J.C., 2013. Mesozoic and Cenozoic squamates of Europe. In: Gardner, J.D., Nydam, R.L. (Eds.), Mesozoic and Cenozoic Lissamphibian and Squamate assemblages of Laurasia. Palaeobiodiversity and Palaeoenvironments 93, 517-534.

Rage, J.C., Augé, M., 2010. Squamate reptiles from the middle Eocene of Lissieu (France). A landmark in the middle Eocene of Europe. Geobios 43, 243-268.

Rage, J.C., Marshall, L.G., Gayet, M., 1993. Enigmatic Caudata (Amphibia) from the Upper Cretaceous of Gondwana. Geobios 26, 515-519.

Rauhut, O.W.M., López-Arbarello, A., 2008. Archosaur evolution during the Jurassic: a southern perspective. Revista de la Asociación Geológica Argentina 63 (4), 559-587.

Rauhut ,O. W. M., Martin, T., Ortiz-Jaureguizar, E., Puerta P., 2002. A Jurassic mammal from South America. Nature 416, 165-168.

Rees, J., Underwood, C.J., 2008. Hybodont sharks of the English Bathonian and Callovian (Middle Jurassic). Palaeontology 51, 117-147.

Richter, A., 1994. Lacertilia aus der Unteren Kreide von Uña und Galve (Spanien) und Anoual (Marokko). Berliner Geowissenschaftliche Abhandlungen E, 14, 1-147. 
Roček, Z., 2013. Mesozoic and Tertiary Anura of Laurasia. In: Gardner, J.D., Nydam, R.L. (Eds.), Mesozoic and Cenozoic Lissamphibian and Squamate assemblages of Laurasia.

Palaeobiodiversity and Palaeoenvironments 93, 397-439.

Rougier, G.W., Martinelli, A.G., Forasiepi, A.M., Novacek, M.J., 2007. New Jurassic mammals from Patagonia, Argentina: A reappraisal of australosphenidan morphology and interrelationships. American Museum Novitates 3566, 1-54.

Saint-Seine, P. de, Casier, E., 1962. Poissons fossiles des couches de Stanleyville (Congo). Deuxième partie: la faune marine des calcaires de Songa. Annales du Musée Royal de l'Afrique Centrale, série in $8^{\circ}$, Sciences Géologiques 44, 1-52.

Schwarz D., Salisbury S.W., 2005. A new species of Theriosuchus (Atoposauridae, Crocodylomorpha) from the Late Jurassic (Kimmeridgian) of Guimarota, Portugal. Geobios 38, 779-802.

Schwarz-Wings, D., Rees, J., Lindgren, J., 2009. Lower Cretaceous Mesoeucrocodylians from Scandinavia (Denmark and Sweden). Cretaceous Research 30, 1345-1355.

Schweitzer, H.-J., Ashraf, A. R., Weiss, M., 1987. Korrelation der Sporenzonen der Oberen Trias und des Jura in mittleren Orient und in Süddeutschland. Geologische Rundschau 76, 923-943.

Sigogneau-Russell, D., 1991a. Découverte du premier mammifère tribosphénique du Mésozoïque moyen d'Afrique. Comptes Rendus de l'Académie des Sciences 313, 1635-1640.

Sigogneau-Russell, D., 1991b. Nouveaux mammifères thériens du Crétacé inférieur du Maroc. Comptes Rendus de l'Académie des Sciences 313, 279-285.

Sigogneau-Russell, D., 1995. Further data and reflections on the tribosphenid mammals (Tribotheria) from the Early Cretaceous of Morocco. Bulletin du Muséum National d'Histoire Naturelle 16, 291-312.

Sigogneau-Russell, D., 2003. Holotherian mammals from the Forest, Marble (Middle Jurassic of England). Geodiversitas 25, 501-537

Sigogneau-Russell, D., Monbaron M., Russell, D.E,. 1988. Découverte de mammifères dans le Mésozoïque moyen d'Afrique. Comptes rendus de l'Académie des sciences, Série II, 307, 10451050.

Sigogneau-Russell, D., Monbaron, M., Kaenel, E. de, 1990. Nouvelles données sur le gisement à Mammifères mésozoïques du Haut-Atlas marocain. Geobios 23, 461-483.

Sigogneau-Russell, D., Evans, S.E., Levine, J.F., Russell, D.A., 1998. The Early Cretaceous microvertebrate locality of Anoual, Morocco: a glimpse at the small vertebrate assemblages of Africa. New Mexico Museum of Natural History and Science Bulletin 14, 177-181.

Simpson, G.G., 1928. A catalogue of the Mesozoic Mammalia in the Geological Department of the British Museum. British Museum (Natural History), London, 1-215. 
Skutchas, P.P., 2006. Mesozoic amphibians from Siberia, Russia. In: Barrett P.M., Evans S.E. (Eds), 9th international symposium on Mesozoic terrestrial ecosystems and biota. Natural History Museum Publications, London, 123-126.

Skutchas, P.P., 2013. Mesozoic salamanders and albanerpetontids of Middle Asia, Kazakhstan, and Siberia. In: Gardner, J.D., Nydam, R.L. (Eds.), Mesozoic and Cenozoic Lissamphibian and Squamate assemblages of Laurasia. Palaeobiodiversity and Palaeoenvironments 93, 441-457.

Skutchas, P.P., Krasnolutskii, S.A., 2011. A new genus and species of basal salamanders from the Middle Jurassic of western Siberia, Russia. Proceedings of the Zoological Institute RAS 315, 167-175.

Skutchas, P.P., Leshchinskiy S.V., Rezvyi A.S., Fayngerts A.V., Krasnolutskii S.A., 2005. Remains of salamanders from the Middle Jurassic of the Krasnoyarsk Territory. In: Rozanov A.Y., Lopatin A.V., Parkhaev P.Y. (Eds), Modern Paleontology: Classical and Newest Methods. Paleontological Institute RAS, Moscow, 121-123. (in Russian).

Skutchas, P.P., Martin, T., 2011. Cranial anatomy of the stem salamander Kokartus honorarius (Amphibia: Caudata) from the Middle Jurassic of Kyrgyzstan. Zoological Journal of the Linnean Society, 161, 816-838.

Soto, M., Perea, D., 2010. Late Jurassic lungfishes (Dipnoi) from Uruguay, with comments on the systematics of Gondwana ceratodontiforms. Journal of Vertebrate Paleontology 30, 10491058.

Sues, H.D., Reisz, R.R., 1995. First record of the early Mesozoic sphenodontian Clevosaurus (Lepidosauria: Rhynchocephalia) from the Southern hemisphere. Journal of Paleontology 69, 123-126.

Sukhanov, V.B., 2006. An archaic turtle, Heckerochelys romani gen. et sp. nov., from the Middle Jurassic of Moscow Region, Russia. Fossil Turtle Research 1, Supplement to Russian Journal of Herpetology 13, 112-118.

Sullivan, C., Wang, Y., Hone, D.W.E., Wang, YQ., Xu, X., Zhang, F., 2014. The vertebrates of the Jurassic Daohugou Biota of northeastern China. Journal of Vertebrate Paleontology 34, 243280.

Sweetman, S.C., Gardner, J.D., 2013. A new albanerpetontid amphibian from the Barremian (Early Cretaceous) Wessex Formation of the Isle of Wight, southern England. Acta Palaeontologica Polonica 58, 295-324.

Taverne, L., Nolf, D., Folie, A., 2007. On the presence of the osteoglossid fish genus Scleropages (Teleostei, Osteoglossiformes) in the continental Paleocene of Hainin (Mons Basin, Belgium). Belgian Journal of Zoology 137, 89-97.

Termier, H., Gubler, J., Lapparent, A.F. de., 1940. Reptiles et poissons du Bathonien d'El-Mers (Moyen-Atlas marocain). Comptes Rendus Hebdomadaires des Séances de l'Académie des Sciences 210, 768-770. 
Thies, D., Windolf, R., Mudroch, A., 1997. First record of Atoposauridae (Crocodylia: Metamesosuchia) in the Upper Jurassic (Kimmeridgian) of northwest Germany. Neues Jahrbuch für Geologie und Paläontologie, Abhandlungen 205, 393-411.

Thulborn, R.A., 1973. Teeth of ornithischian dinosaurs from the Upper Jurassic of Portugal. Memórias dos Serviços Geológicos de Portugal, Nova Série 22, 89-134.

Thusu, B., Vigran, J.O., 1985. Middle - Late Jurassic (Late Bathonian -Tithonian) Palynomorphs. In: Thusu B., Owens B. (eds), Palynostratigraphy of north-east Libya. Journal of Micropalaeontology 4, 113-120.

Thusu, B., Van der Eem, J.G.L.A., El-Mehdawi, A., Bu-Argoub, F., 1988. Jurassic - Early Cretaceous palynostratigraphy in northeast Libya. In: El-Arnauti A., Owens B., Thusu B. (Eds), Subsurface Palynostratigraphy of northeast Libya, Garyounis University Publications, Benghazi, 171-213.

Tong, H., Buffetaut, E., Suteethorn, V., 2002. Middle Jurassic turtles from southern Thailand. Geological Magazine 139, 687-697.

Trueb, L., 1993. Patterns of cranial diversity among the Lissamphibia. In: Hanken J.,Hall B.K. (Eds), The skull. Vol. 2, Patterns of structural and systematic diversity. University of Chicago Press, 255343.

Van Erve, A.W. ,1977. Palynological investigation in the Lower Jurassic of the Vicentinian Alps (Northeastern Italy). Review of Palaeobotany and Palynology 23, 1-117.

Vasilyan, D., Böhme, M., Chkhikvadze, V.M., Semenov, Y.A., Joyce, W.G., 2013. A new giant salamander (Urodela, Pancryptobrancha) from the Miocene of eastern Europe (Grytsiv, Ukraine). Journal of Vertebrate Paleontology 33, 301-318.

Venczel M., Gardner, J.D., 2005. The geologically youngest albanerpetontid amphibian, from the Lower Pliocene of Hungary. Palaeontology 48, 1273-1300.

Vignaud, P., 1997. Morphologie dentaire des Thalattosuchia (Crocodylia, Mesosuchia). Palaeovertebrata 26, 35-59.

Vitek, N.S., Danilov, I.G., 2014. Soft-shelled turtles (Trionychidae) from the Cenomanian of Uzbekistan. Cretaceous Research 49, 1-12.

Vullo, R., Abit, D., Ballèvre, M., Billon-Bruyat, J., P., Bourgeais, R., Buffetaut, E., Daviero-Gomez, V., Garcia, G., Gomez, B., Mazin, J.-M., Morel, S., Néraudeau, D., Pouech, J., Rage, J.-C., Schnyder, J., Tong, H., 2014. Palaeontology of the Purbeck-type (Tithonian, Late Jurassic) bonebeds of Chassiron (Oléron Island, western France). Comptes Rendus Palevol, 13, 421-441.

Vullo, R., Courville, P. , 2014. Fish remains (Elasmobranchii, Actinopterygii) from the Late Cretaceous of the Benue Trough, Nigeria. Journal of African Earth Sciences 97, 194-206.

Waldman, M., Evans, S.E., 1994. Lepidosauromorph reptiles from the Middle Jurassic of Skye. Zoological Journal of the Linnean Society $112,135-250$. 
Wang, J., Shen, T., Ju, J., Yang, G., 2011. The complete mitochondrial genome of the Chinese longsnout catfish Leiocassis longirostris (Siluriformes: Bagridae) and a time-calibrated phylogeny of the ostariophysan fishes. Molecular Biology Reports 38, 2507-2516.

Wang, X., Campos ,D. de A., Zhou, Z., Kellner, A.W.A., 2008. A primitive isitiodactylid pterosaur (Pterodactyloidea) from the Jiufotang Formation (Early Cretaceous), northeast China. Zootaxa 1813, 1-18.

Wang ,X., Kellner, A.W.A., Jiang, S., Cheng, X., Meng, X., Rodrigues, T., 2010. New long-tailed pterosaurs (Wukongopteridae) from western Liaoning, China. Anais da Academia Brasileira de Ciências 82, 1045-1062.

Werner, C., 1994. Die continental Wirbeltierfauna aus der unteren Oberkreide des Sudan (Wadi Milk Formation). Berliner Geowissenschaftliche Abhandlungen E 13, 221-249.

Wiechmann, M.F., Gloy , U., 2000. Pterosaurs and urvogels from the Guimarota mine. In: Martin, T., Krebs, B. (Eds.), Guimarota - A Jurassic Ecosystem. Verlag Friedrich Pfeil, München, 83-86.

Wilkinson, M., San Mauro, D., Sherratt, E., Gower, D., 2011. A nine-family classification of caecilians (Amphibia: Gymnophiona). Zootaxa 2874, 41-64.

Xu, G.-H., Zhao, L.-J., Coates, M.I., 2014. The oldest ionoscopiform from China sheds new light on the early evolution of halecomorph fishes. Biology Letters 10, 1-5.

Yen, T.-C., Reeside, J.B., 1952. Molluscan fauna of the Morrison Formation. United States Geological Survey Professional Paper 233-B, 21-51. 


\section{Caption of figures and tables}

\section{Figures}

Fig. 1. Geographic and geological settings of the investigated outcrop areas. A: location of the study area in Eastern High Atlas. B: simplified geological map of the Anoual Syncline (from du Dresnay, 1976; Caïa, 1972; Haddoumi et al., 2008) showing the vertebrate localities of Guelb el Ahmar (GEA, Anoual Fm, Bathonian) and Ksar Metlili (KM, Ksar Metlili Fm, ?Berriasian).

$<<2$ columns $>>$

Fig. 2. Synthetic stratigraphical log and sequential evolution of the "Red Beds" exposed in the Anoual Syncline, with stratigraphic location of the Guelb el Ahmar (GEA) and Ksar Metlili (KM) vertebrate bearing levels in the Anoual and Ksar Metlili formations, respectively (from Haddoumi et al. 2008, fig. 2)

\section{$<<1.5$ columns $>$}

Fig. 3. Outcrops of the Anoual Formation at Guelb el Ahmar showing the Bathonian lacustrine fossiliferous limestone (green to grey level) by the GEA 1 site, Anoual Syncline, Morocco. The uprighted marine middle Jurassic limestone forming the northern flank of the Anoual Syncline are visible in the distance.

$<<1.5$ columns $>>$

Fig. 4. Guelb el Ahmar microvertebrate sites GEA 3 and GEA 2 from the Bathonian Anoual Fm (Anoual Syncline, Morocco). Detailed section showing relative position of the two local fossiliferous levels that were sampled for microvertebrates research. GEA 3 is found in a lower lacustrine limestone level, and GEA 2 belongs to the overlying upper brown marl level.

$<<2$ columns $>>$

Fig. 5. Screening-washing operations of the fossiliferous sediment from the Bathonian Guelb el Ahmar GEA 2 locality. Successive steps in the washing-screening process on the field included 1) drying sediment under sunlight, 2) soaking the sediment in water with the addition of hydrogen peroxide (help to deflocculate the clay matrix), 3) screening-washing on 3 superposed large sieves (meshes $0.8 \mathrm{~mm}, 2 \mathrm{~mm}, 4 \mathrm{~mm}$ ) with the help of a water-pump, 4) drying the screened residue and sorting the size grain fraction larger than $4 \mathrm{~mm}$ (mostly including turtle and crocodilian remains, and some dipnoan teeth). 1.2 ton of sediment of GEA 2 locality was screen-washed for recovery of the microvertebrate fauna that is described in this work.

$<<1$ column $>>$

Fig. 6. Flora from Guelb el Ahmar and Oued Metlili Lignites, Anoual Fm, Bathonian: Palynomorpha and wood fragments. Each illustrated palynomorph and wood fragment is followed by sample number, slide number and coordinates of the England Finder Graticule (brackets).

A-H. Samples from Guelb el Ahmar loc. 2 (GEA 2). A. Pityosporites sp., GEA 2 C (S55/3). B. Araucariacites australis Couper, GEA 2 A (F36). C. Alisporites sp., GEA 2 A (K52/4). D. Classopollis sp., 
GEA 2 A (W53/4). E. Bisaccates sp., GEA 2 A (P41/4). F. Inaperturopollenites sp., GEA 2 A (H43/4). G. Cycadopites sp., GEA 2 B (T40/3). H. Tangential longitudinal wood section showing the uniseriate rays, GEA 2 C (J70). A-G: Scale bar $=20 \mu \mathrm{m}$. H: Scale bar: $25 \mu \mathrm{m}$.

I-N. Oued Metlili Lignites sample (OML). I-M Wood fragments showing the uniseriate or biseriate bordered pits on the wall of tracheids. N. Cross-field with araucarioid pits. I. OML A (N54/4); J. OML A observed in water; K. OML A (O69/3); L. OML A (P44/1); M. OML B (X67/4); N. OML A observed in water. I-N: Scale bar: $25 \mu \mathrm{m}$.

$<<2$ columns $>>$

Fig. 7. Flora from the Anoual Formation (Bathonian). Locality from Anoual Syncline rich in fossil trunks of conifer gymnosperms (arrows); corresponding pollen of Cheirolepidiaceae (Classopollis) have been identified in the fossiliferous marls of Guelb el Ahmar (GEA 2 loc.).

$<<1.5$ columns $>$

Fig. 8. Non-vertebrate taxa (Charophyta, Ostracoda, Gastropoda) of Guelb El Ahmar (Bathonian). A. gyrogonite (GEA 2-unnumbered) of Charophyta indet. B. carapace (GEA 2-unnumbered) of Ostracoda indet. C. shell (GEA 2-unnumbered) of Planorbidae indet. D. shell (GEA 2- unnumbered) of Lymnaeidae indet. E. shell (GEA 2- unnumbered) of Valvatidae indet. Scale bars: $100 \mu \mathrm{m}(\mathrm{A}, \mathrm{B})$ and $1 \mathrm{~mm}(\mathrm{C}-\mathrm{E})$.

$<<1.5$ columns $>$

Fig. 9. Guelb El Ahmar fauna. Osteichthyes. A. GEA 2-14, tooth of Lepidotes sp. or Scheenstia sp. B. GEA 2-17, scale of cf. lonoscopiformes indet. C. GEA 2-16, squamule of Osteoglossiformes indet. D. squamule (unnumbered specimen) of Osteoglossiformes indet. from Ksar Metlili (?Berriasian) for comparison. E, F. GEA 2-13, GEA 2-12, ichthyoliths of Osteichthyes indet. Scale bars: $1 \mathrm{~mm}$.

$<<1.5$ columns $>>$

Fig. 10. Guelb El Ahmar fauna. Osteichthyes. A. GEA 3-1, scale of Lepidotes sp. or Scheenstia sp. B. GEA 3-2, spine of Pisces indet. C-E. parasphenoid tooth plate (C: GEA 3-3) and indeterminate skull elements (D, E: GEA 3-4, GEA 3-5) of Mawsoniidae indet. F, G. GEA 3-6, GEA 3-7, teeth of Arganodus sp. Scale bars: $10 \mathrm{~mm}$.

$<<1.5$ columns $>>$

Fig. 11. Guelb El Ahmar fauna. Lissamphibia. A, B. Incomplete premaxilla (A: GEA 2-22) and frontal (B: GEA 2-21) of Albanerpetontidae indet. C. GEA 2-29, fragment of dentary of ?Caudata indet. D. GEA 2-2, incomplete right maxilla of ?Lissamphibia incertae sedis (see also Supplementary S1 Figure 1). A1: lingual view; $A 2$ : labial view. $B 1$ : ventral view; $B 2$ : dorsal view. $C 1$ : labial view; $C 2$ : lingual view; C3: outlined section. D1: dorsal view; D2: ventral view; D3: labial view; D4: lingual view. Scale bars: 1 $\mathrm{mm}$.

$<<1.5$ columns $>>$

Fig. 12. Guelb El Ahmar fauna. Testudinata. A. GEA 2-47, costal plate of Testudinata indet. 1. B. GEA 2-48, neural plate of Testudinata indet. 2. C, D. costal (C: GEA 3-8) and peripheral (D: GEA 3-9) plates 
of Testudinata indet. 3. E. GEA 2-49, costal plate of Testudinata indet. 4. Scale bars: $5 \mathrm{~mm}$ (E) and 10 $\mathrm{mm}(\mathrm{A}-\mathrm{D})$.

\section{$<<1.5$ columns $>$}

Fig. 13. Guelb El Ahmar fauna. Lepidosauria. A, B. Fragment of left dentary (A: GEA 2-20) and fragment of maxilla (B: GEA 2-18) of Rhynchocephalia indet. C. GEA 2-26, fragment of jaw of Scincomorpha indet. D. GEA 2-28, fragment of jaw of ?Scincomorpha indet. in lingual view. E. GEA 230, vertebra of cf. Parviraptor sp. F, G. Left maxilla (F: GEA 2-24) and vertebra (G: GEA 2-25) of nonophidian squamates. A: labial view; B1: labial view; B2: occlusal view. C1: lingual view; C2: close up of teeth. F: lingual view. G: ventro-lateral view. Scale bars: $100 \mu \mathrm{m}$ (C2), $500 \mu \mathrm{m}$ (A, C1, D-F) and $1 \mathrm{~mm}$ $(B, G)$.

\section{$<<2$ columns $>>$}

Fig. 14. Guelb El Ahmar fauna. Archosauromorpha (Choristodera, Dinosauria, Pterosauria). A, B. dentary (A: GEA 2-31) and vertebral centrum (B: GEA 2-23) of cf. Choristodera. C. GEA 2-5, tooth of Theropoda indet. D. GEA 2-4, tooth of Stegosauria indet. E. GEA 2-3, tooth of Ornithischia indet. F. GEA 2-7, tooth of Rhamphorhynchidae indet. G-I. teeth (GEA 2-6, GEA 2-50, GEA 2-51) of Pterosauria indet. A: lingual view. B: anterior or posterior view. Scale bars: $100 \mu \mathrm{m}(C 2)$ and $1 \mathrm{~mm}(\mathrm{~A}-\mathrm{C} 1, \mathrm{D}-\mathrm{I})$.

\section{$<<1.5$ columns $>>$}

Fig. 15. Guelb El Ahmar fauna. Archosauromorpha (Crocodyliformes). A-D. Anterior to posterior teeth (GEA 2-8, GEA 2-9, GEA 2-10, GEA 2-11) of cf. Theriosuchus sp. Scale bars: $100 \mu \mathrm{m}$ (D4, D5) and $1 \mathrm{~mm}(\mathrm{~A}-\mathrm{D} 3)$.

\section{$<<2$ columns $>>$}

Fig. 16. Guelb El Ahmar fauna. Archosauromorpha (Crocodyliformes). A, B. GEA 2-52, GEA 2-53, teeth of Atoposauridae indet. C. GEA 2-54, tooth of Teleosauridae indet. D-G. tooth (D: GEA 3-10), vertebra (E: GEA 3-11), femur (F: GEA 3-12) and osteoderm (G: GEA 3-13) of Thalattosuchia indet. (?Metriorhynchidae). Scale bars: $1 \mathrm{~mm}(\mathrm{~A}-\mathrm{C})$ and $10 \mathrm{~mm}(\mathrm{D}-\mathrm{G})$.

$<<1.5$ columns $>$

Fig. 17. Guelb el Ahmar fauna. Mammalia from locality GEA 2.

A-C. Amphitheriidae (stem zatherian, Cladotheria) g., sp. indet. GEA 2-1, fragment of right dentary of a juvenile individual with one fully erupted premolar $\left(\mathrm{P}_{2}\right.$ or $\mathrm{P}_{3}$ ? $)$ and one more posterior premolar $\left(\mathrm{P}_{3}\right.$ or $\mathrm{P}_{4}$ ? $)$ still in crypt; occlusal stereophotographic $(\mathrm{A})$, labial $(\mathrm{B})$ and lingual (C) s.e.m. views.

D-F. Amphitheriidae g., sp. indet. GEA 2-32, fragment of right dentary with 3 alveoli (teeth broken, but remain of at least one root); occlusal (D) and labial (E) s.e.m. views; X-ray radiographs in labial $(F)$ and lingual $(G)$ views.

$\mathrm{H}-\mathrm{O}$. Amphitheriidae g., sp. indet. GEA 2-1. CT scan 3 D modellings. $\mathrm{H}-\mathrm{L}$, the right dentary in occlusal (stereographic), distal, labial, lingual and mesial, views; M-O. Permanent anterior 
premolars $\mathrm{P}_{2}$ or $\mathrm{P}_{3 \text { ? }}$ and $\mathrm{P}_{3}$ or $\mathrm{P}_{4 \text { ? }}$ in crypt in lingual, occlusal and labial views. See also Supplementary S1 Figure 2.

P-Q. cf. Mammalia, cf. Dryolestida indet. GEA 2-33, tooth fragment (cusp and root) in occlusal and lateral s.e.m. view. Fragment of left upper molar, probably the paracone with its root.

mf: mental foramen; md: mandibular canal; Is: inflated lingual side

Scale bar: $1 \mathrm{~mm}$

$<<2$ columns $>>$

Fig. 18. Guelb el Ahmar fauna. Mammalia from locality GEA 2. Amphitheriidae (stem zatherian, Cladotheria) indet. Posterior and anterior fragments of right lower jaws.

$A, B, C$. Amphitheriidae g., sp. indet. Specimen GEA 2-1, fragment of right dentary of a juvenile individual with one fully erupted premolar $\left(\mathrm{P}_{2}\right.$ or $\mathrm{P}_{3}$ ? $)$ and one more posterior premolar $\left(\mathrm{P}_{3}\right.$ or $P_{4}$ ?) still in crypt; occlusal, labial and lingual views.

D, E, F. Amphitheriidae g., sp. indet. Specimen GEA 2-32, fragment of right dentary with 3 alveoli; occlusal, lingual and labial views.

Scale bar: $1 \mathrm{~mm}$

$<<1$ column $>>$

Fig. 19. Paleogeographic reconstruction showing location of the site of Guelb el Ahmar (Anoual Syncline, Morocco), close to the crossing area of the incipient Central Atlantic and Tethyan seas. Paleogeographic peri-Tethyan context for the Middle Jurassic (Callovian) from Barrier and Vrielynck (2008), map 3.

$<<1.5$ columns $>>$

\section{Tables}

Table 1. Mammalia, Amphitheriidae g., sp. indet.: measurements of GEA 2-1 and GEA 2-32 $(\mathrm{mm})$. Measurements were made under binocular Measuroscope (Nikon, MM400 SL), except for length and width of the replacing tooth $\mathrm{P}_{2}$ or $\mathrm{P}_{3}$ of GEA 2-1 that was measured on the $3 \mathrm{D}$ model of the tooth with the help of the program MIMICS. L= Length: $W=$ width. *maximal preserved length.

$<<1$ column $>>$

Table 2. Faunal list of the vertebrate taxa from the Guelb el Ahmar locality, Anoual Formation, Bathonian, eastern Morocco.

$<<1.5$ columns $>>$

Table 3. Main Jurassic microvertebrate localities known in Africa and other Gondwanan continents.

$<<2$ columns $>>$ 
Table 4. Taxa from GEA recorded in other Middle Jurassic vertebrates sites from Gondwana. The comparison does not include the poorly known Early Jurassic faunal assemblage of Queso Rallado, Argentina. Taxa in parentheses are different from those of GEA. (1) Caudata and Rhynchocephalia are reported in Ambondromamy, but the determination is wrong (see text); (2) different taxon from that of GEA.

$<<1.5$ columns $>$

Table 5. Taxa from GEA shared with Middle Jurassic fauna from Laurasia. Taxa in parentheses are different from those of GEA.

$<<2$ columns $>>$

Table 6. Comparison of GEA and Ksar Metlili faunas, respectively Bathonian and ?Berriasian of Anoual Syncline, eastern Morocco.

$<<2$ columns $>>$ 


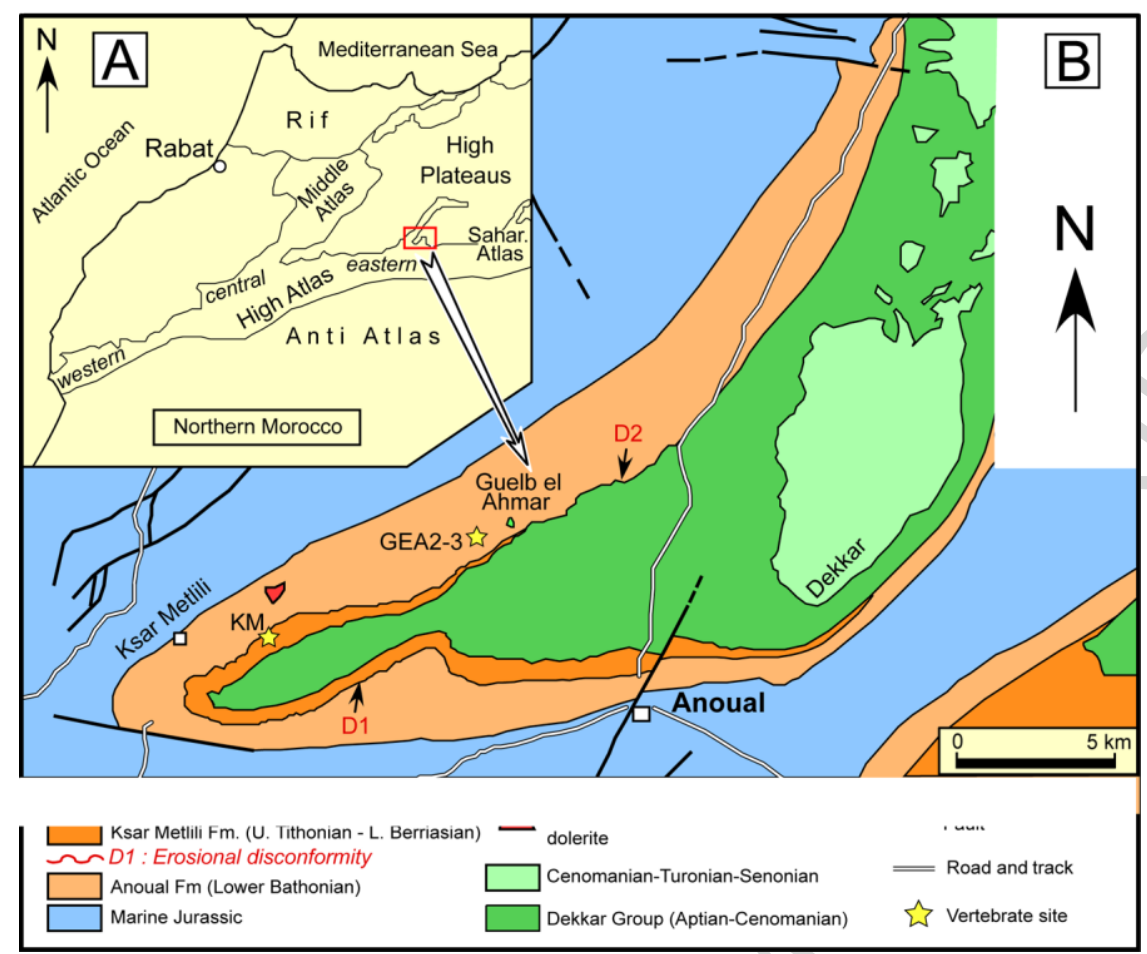

Figure 1 


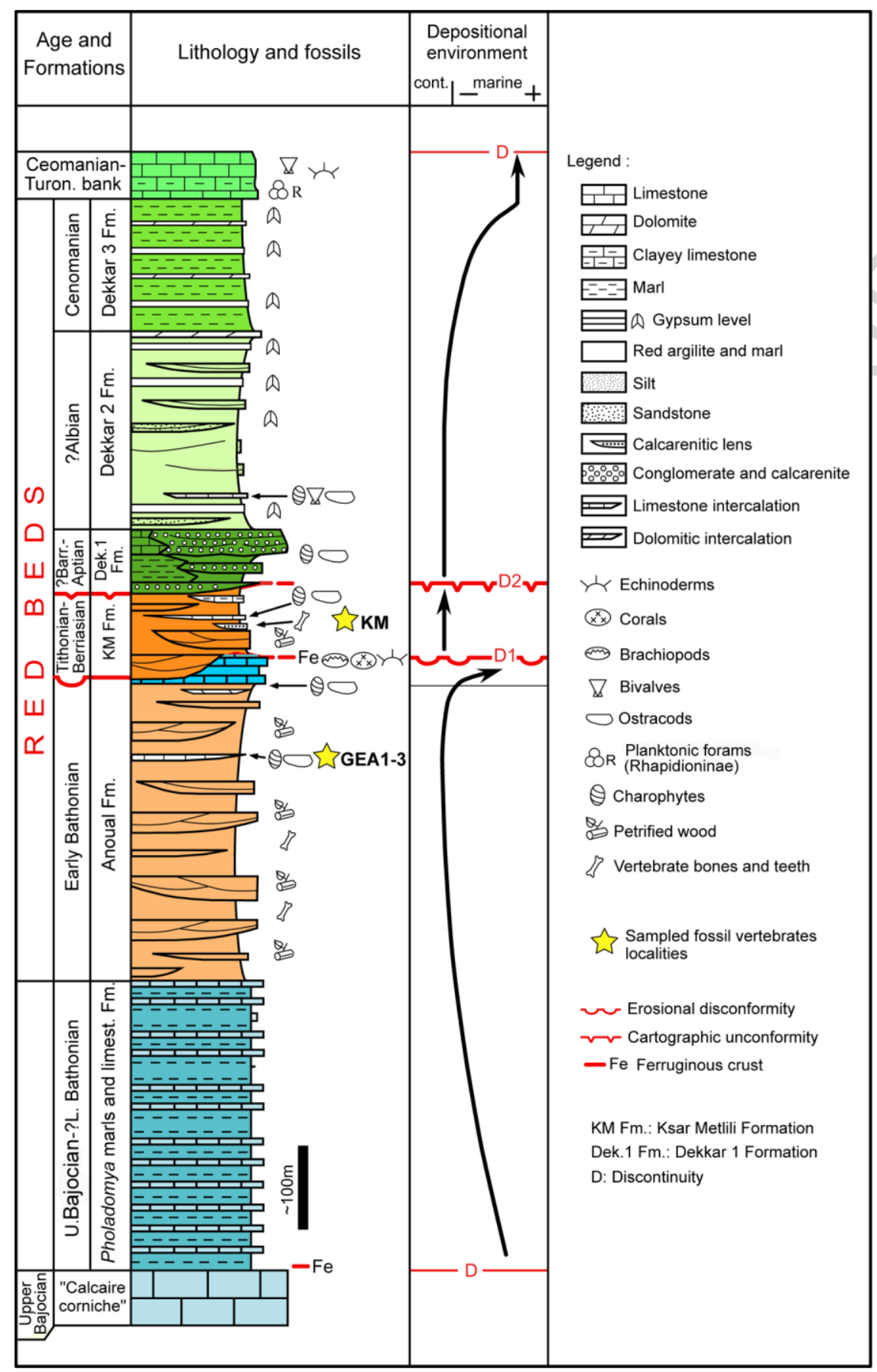

Figure 2 


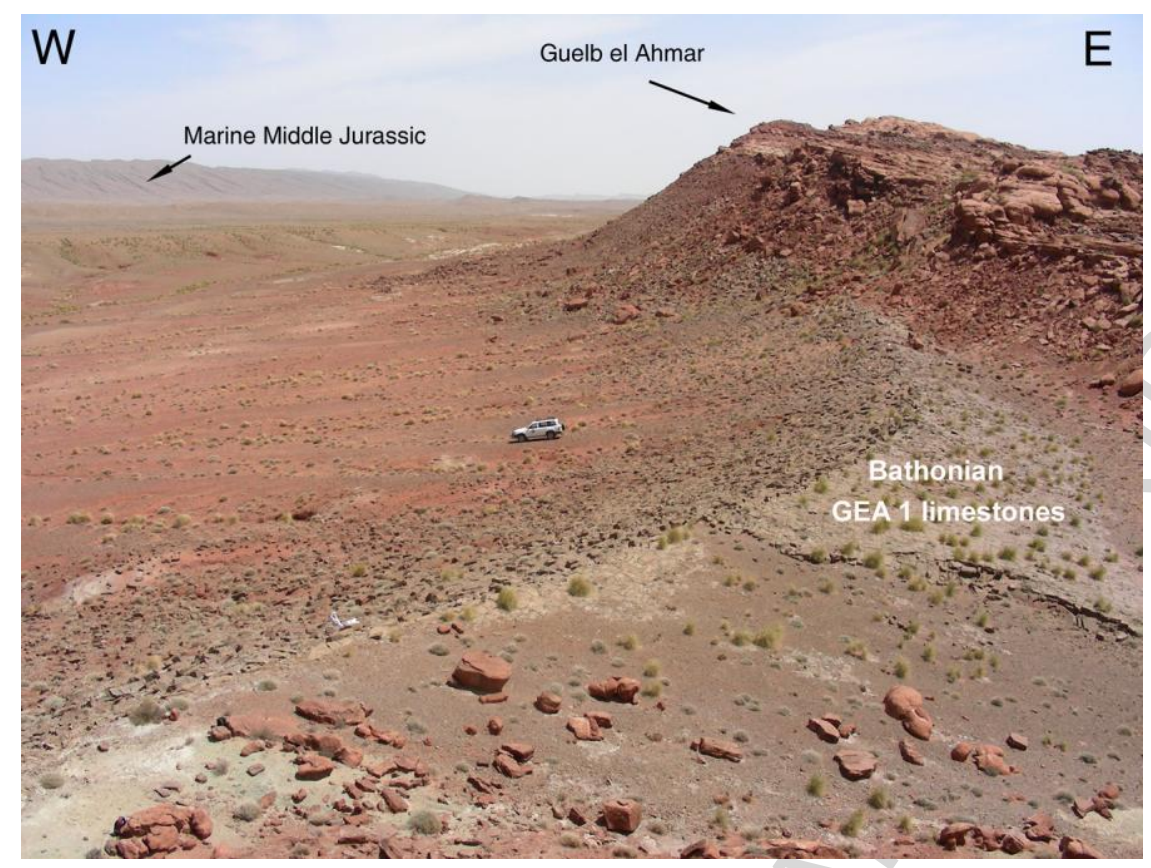

Figure 3 

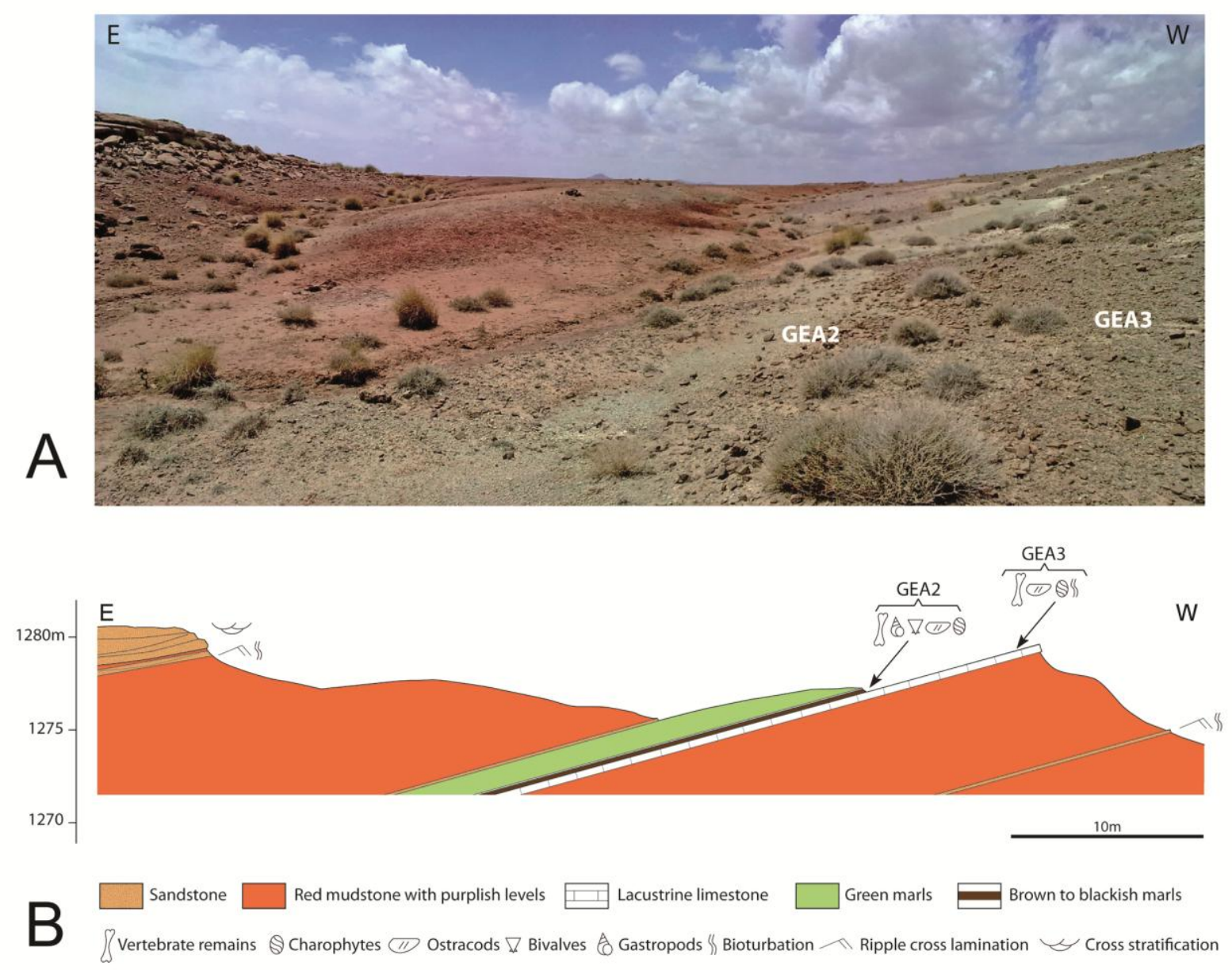

Figure 4 


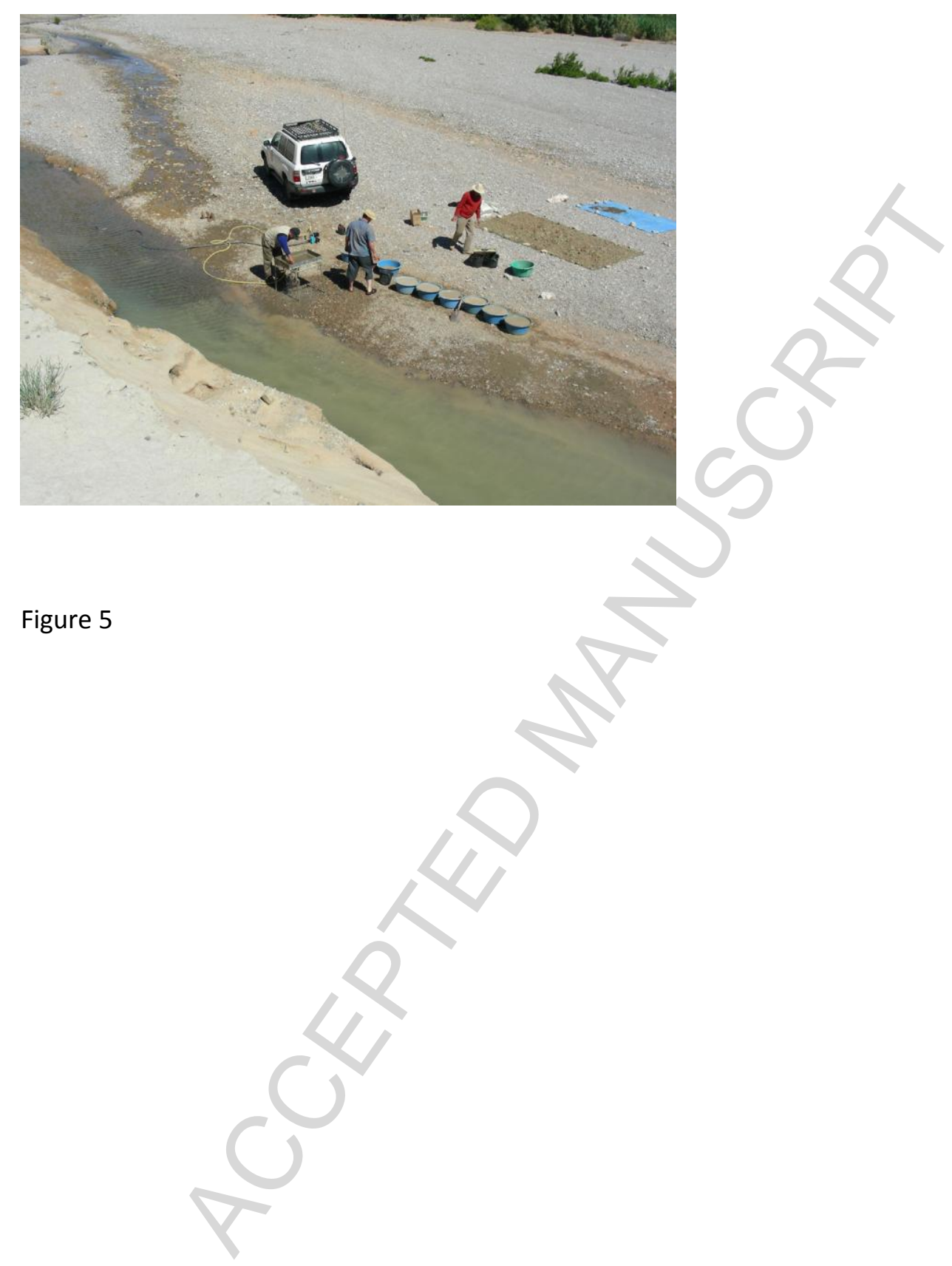



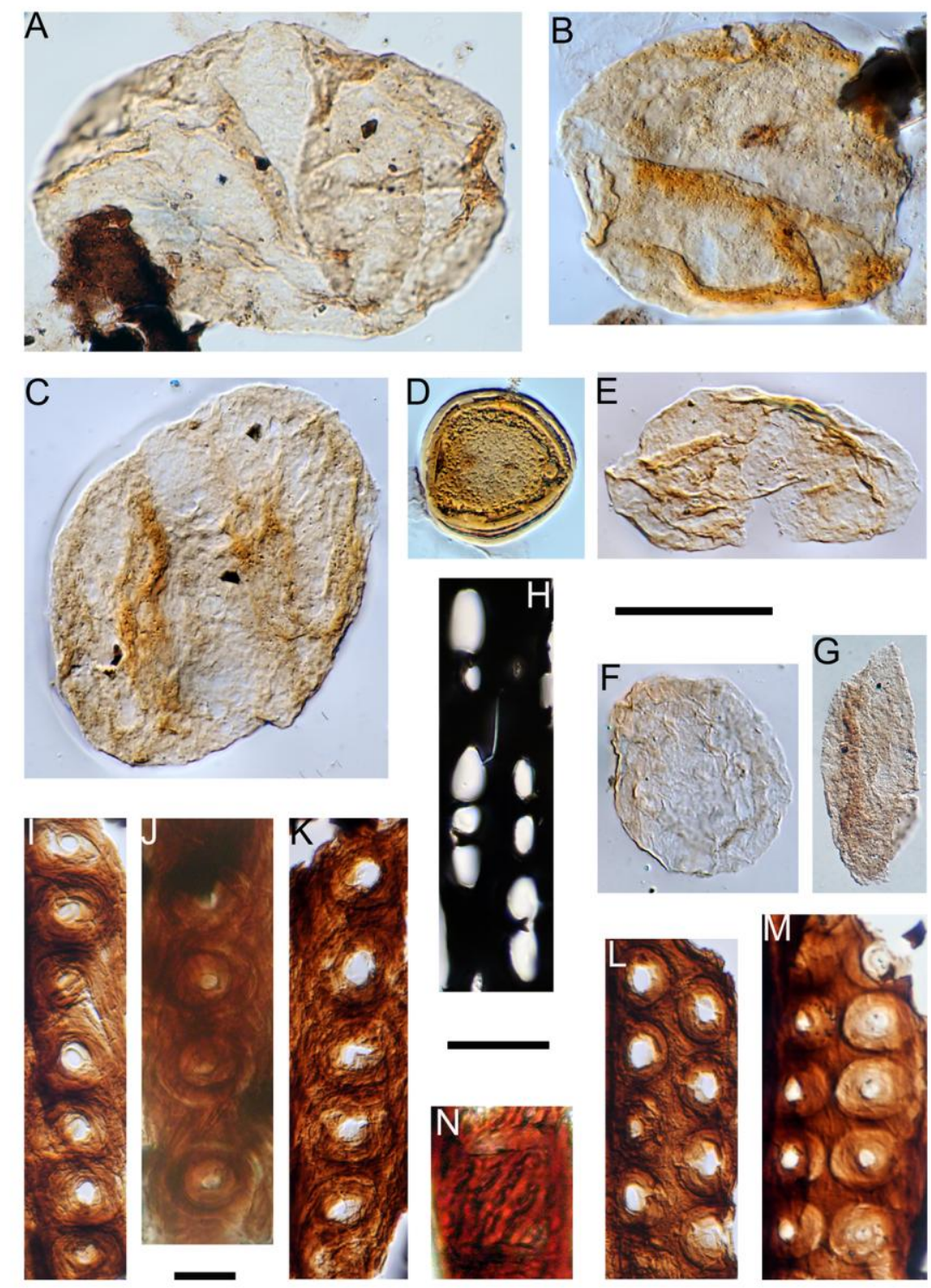

Figure 6 


\section{ACCEPTED MANUSCRIPT}

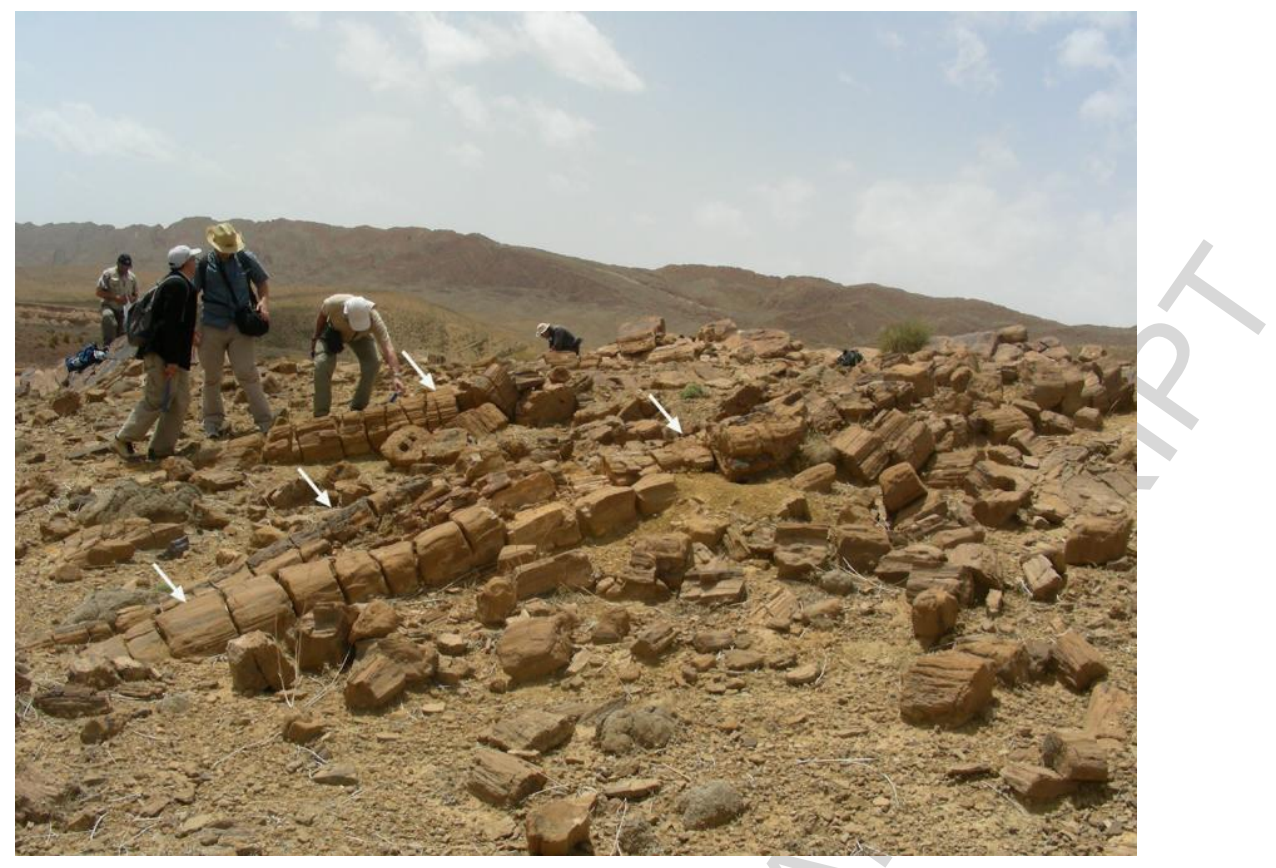

Figure 7 


\section{ACCEPTED MANUSCRIPT}

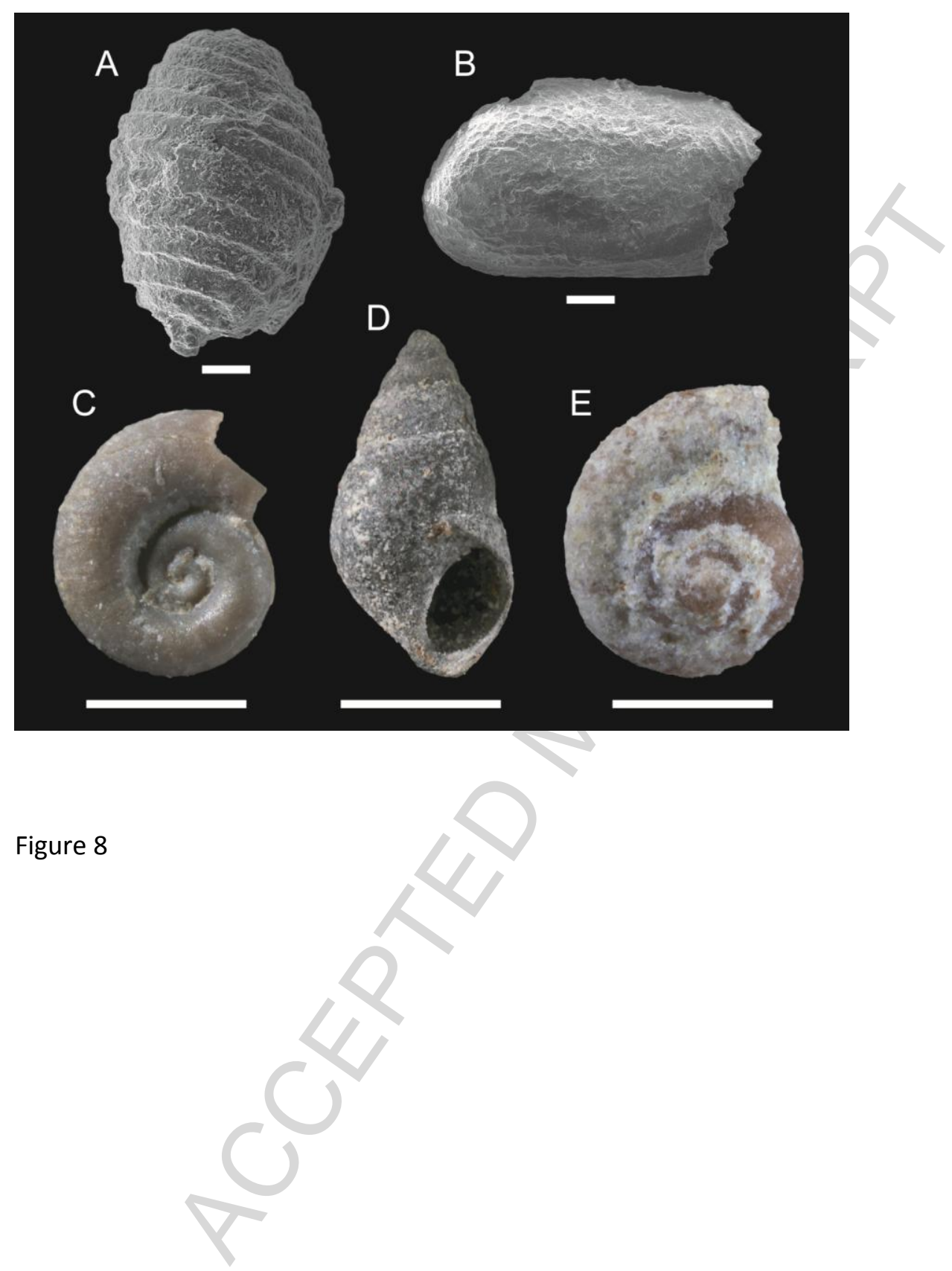




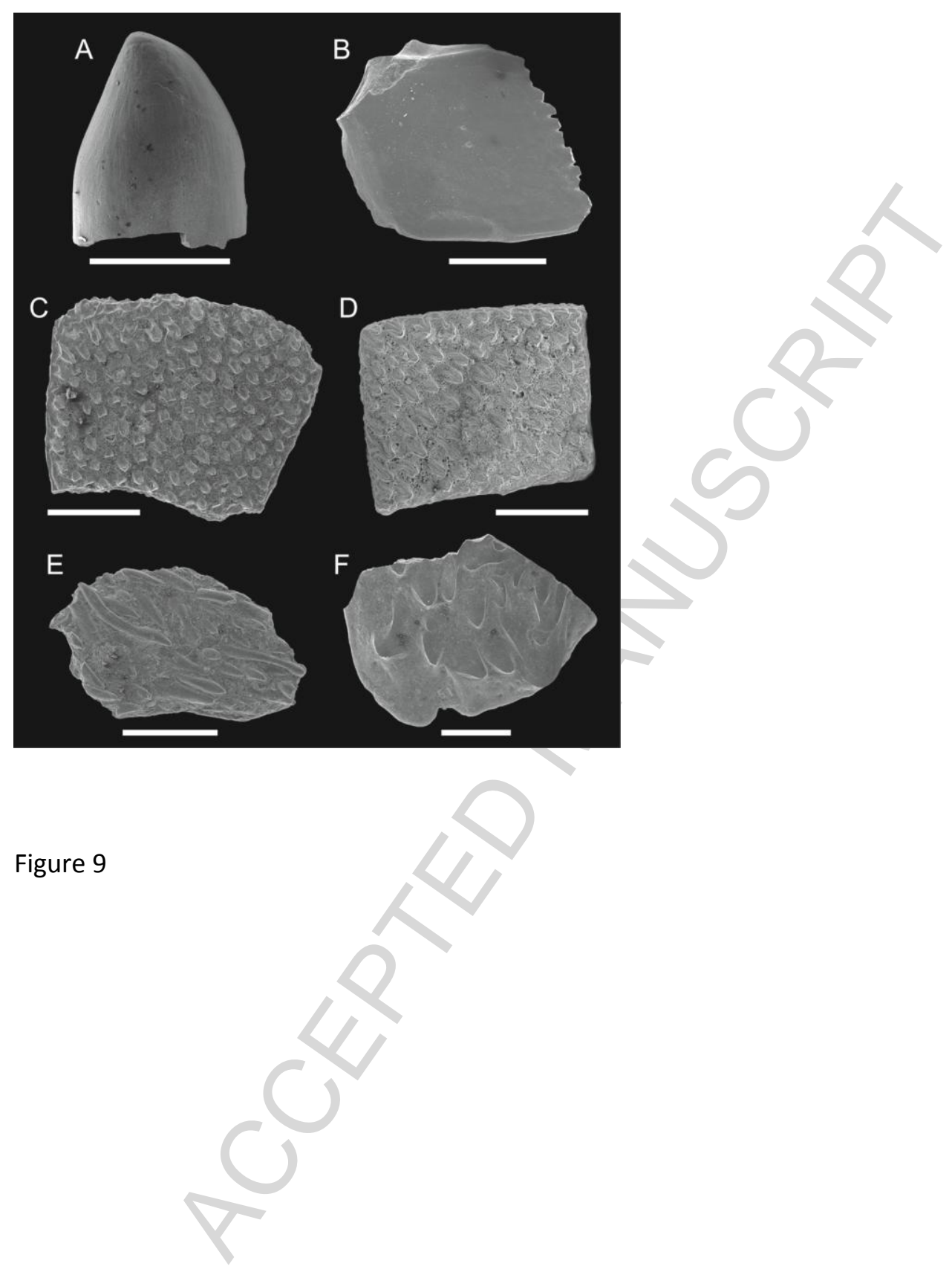



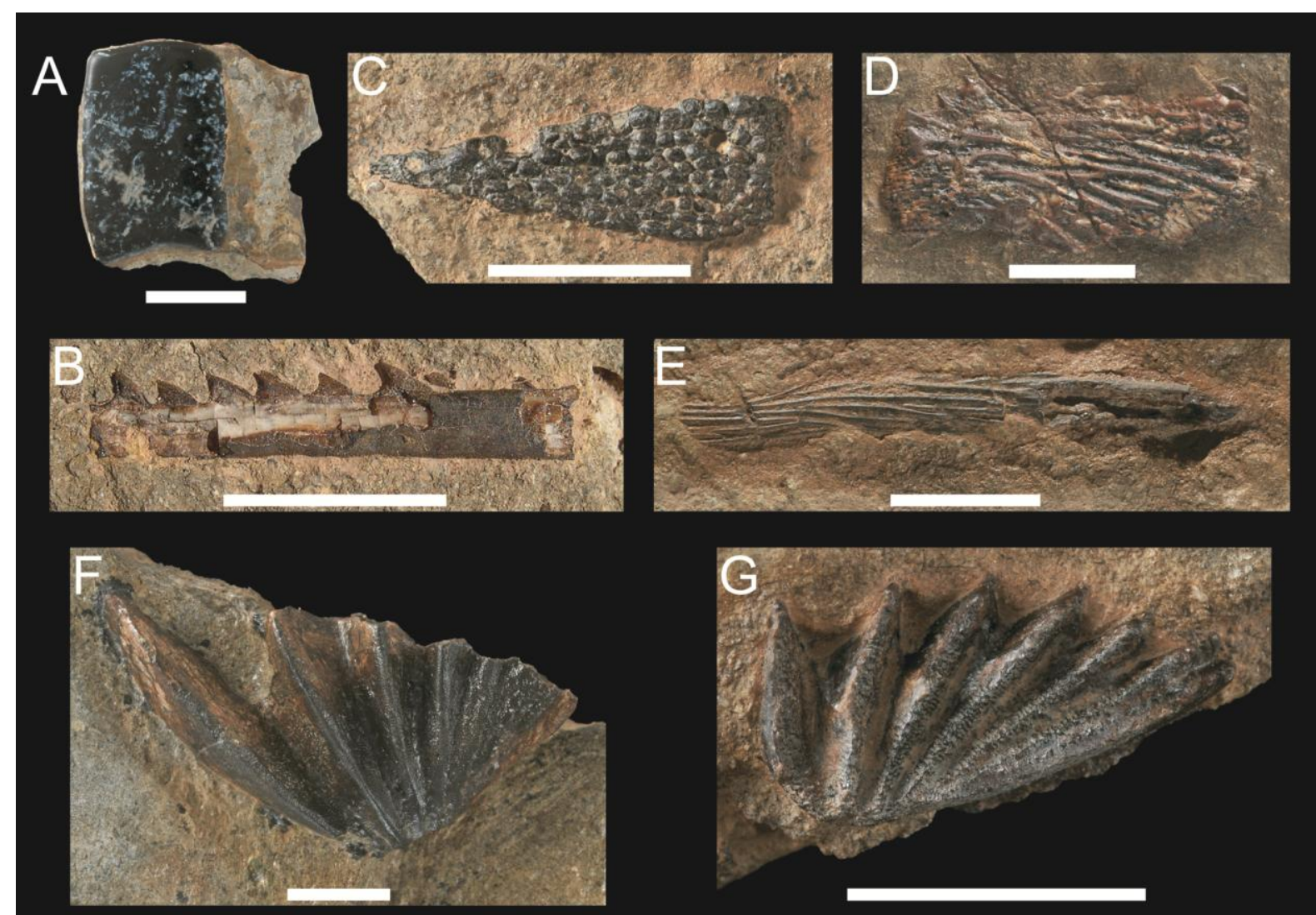

Figure 10 


\section{ACCEPTED MANUSCRIPT}

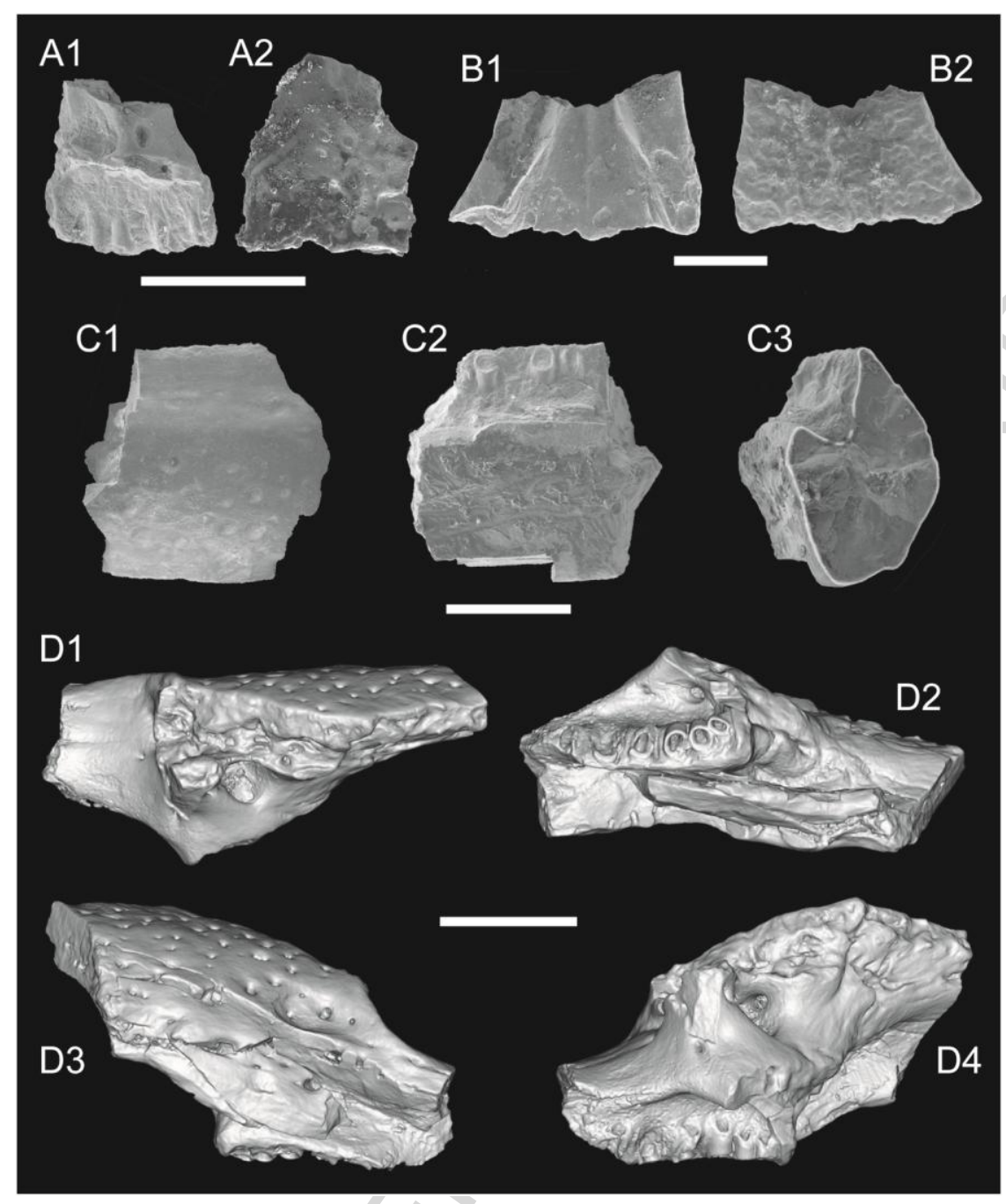

Figure 11 


\section{ACCEPTED MANUSCRIPT}

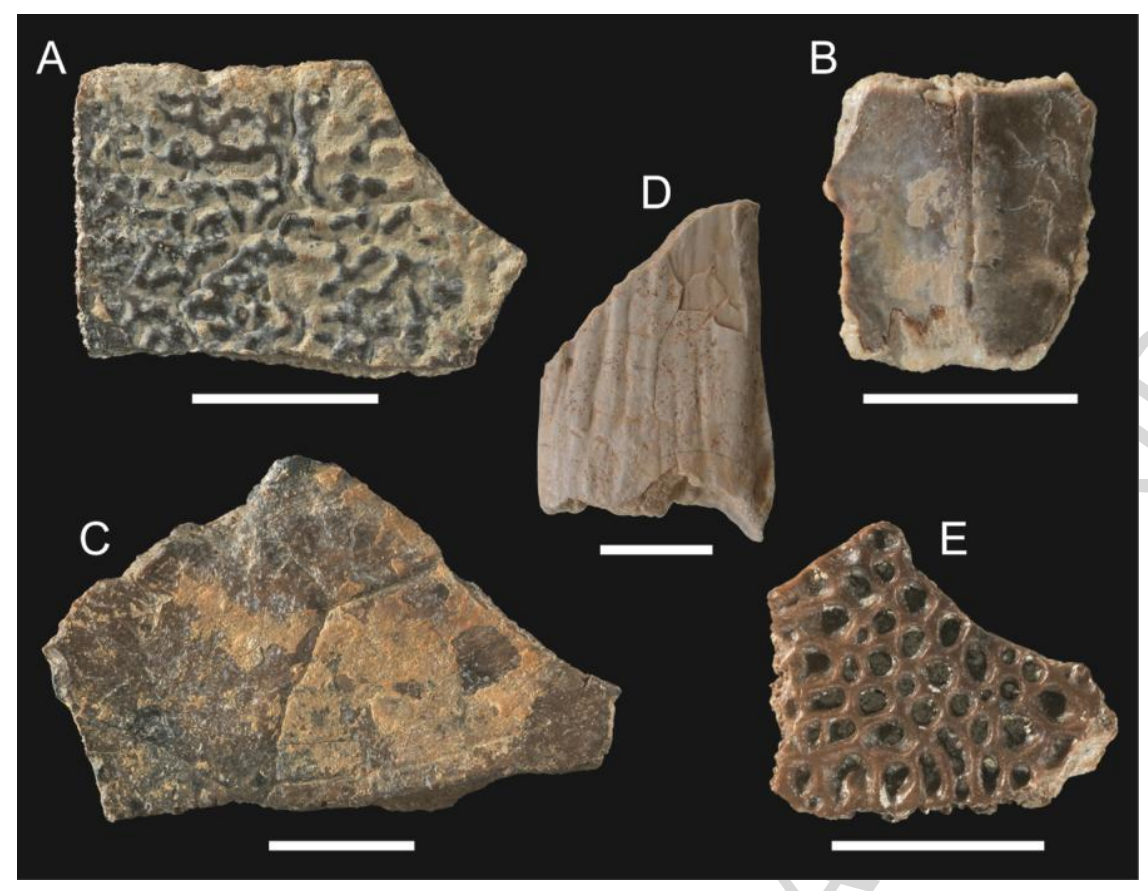

Figure 12 


\section{ACCEPTED MANUSCRIPT}

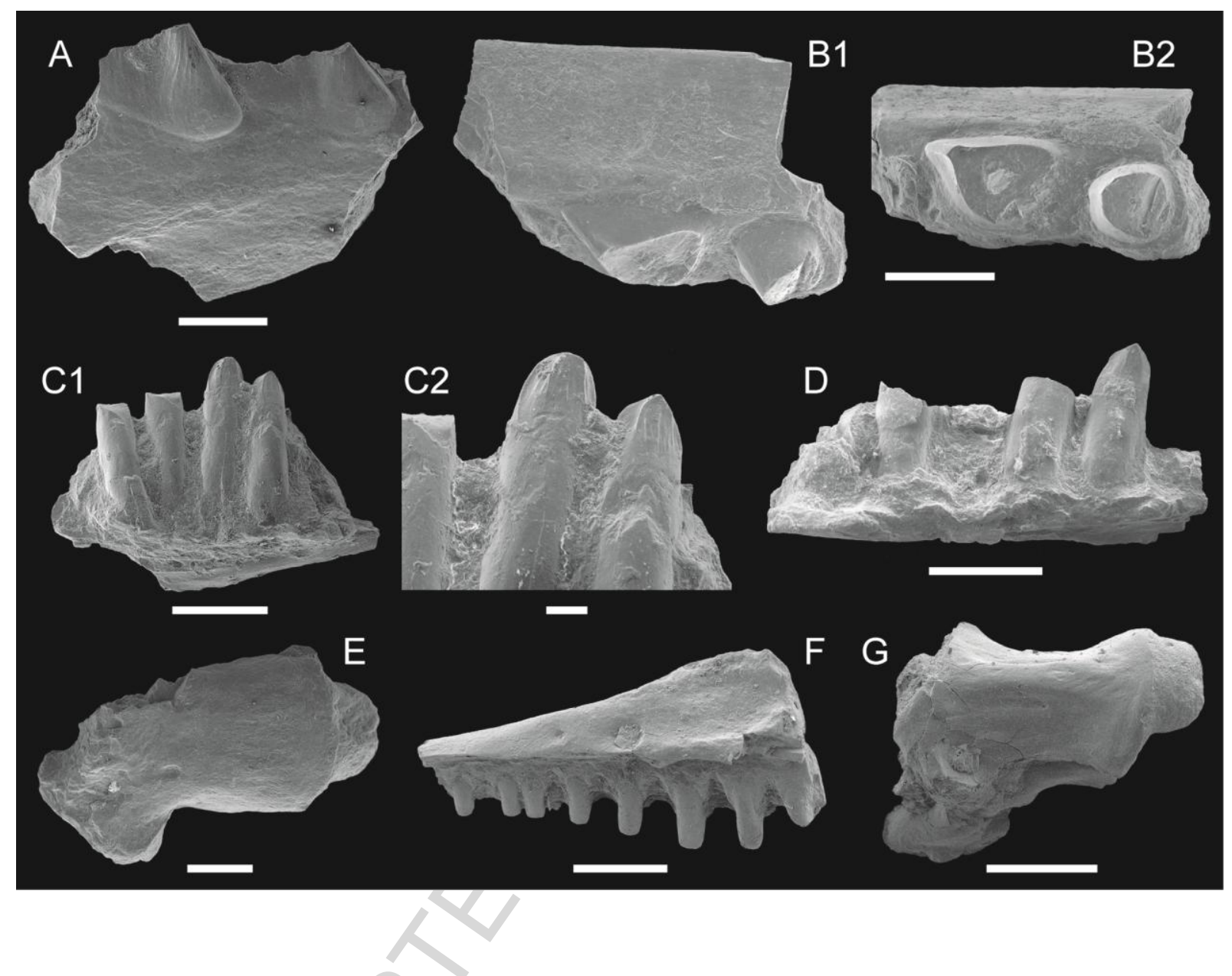

Figure 13 


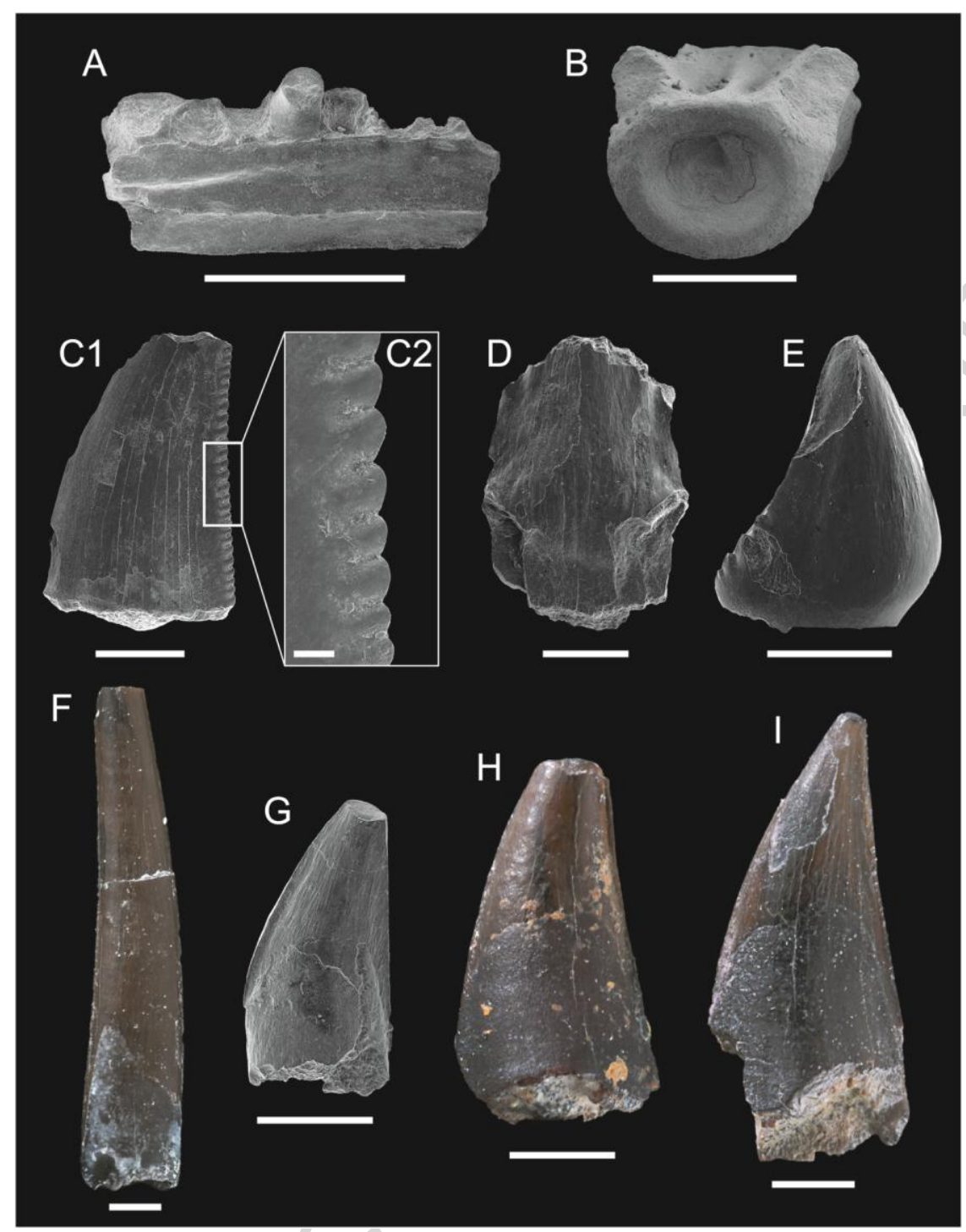

Figure 14 


\section{ACCEPTED MANUSCRIPT}

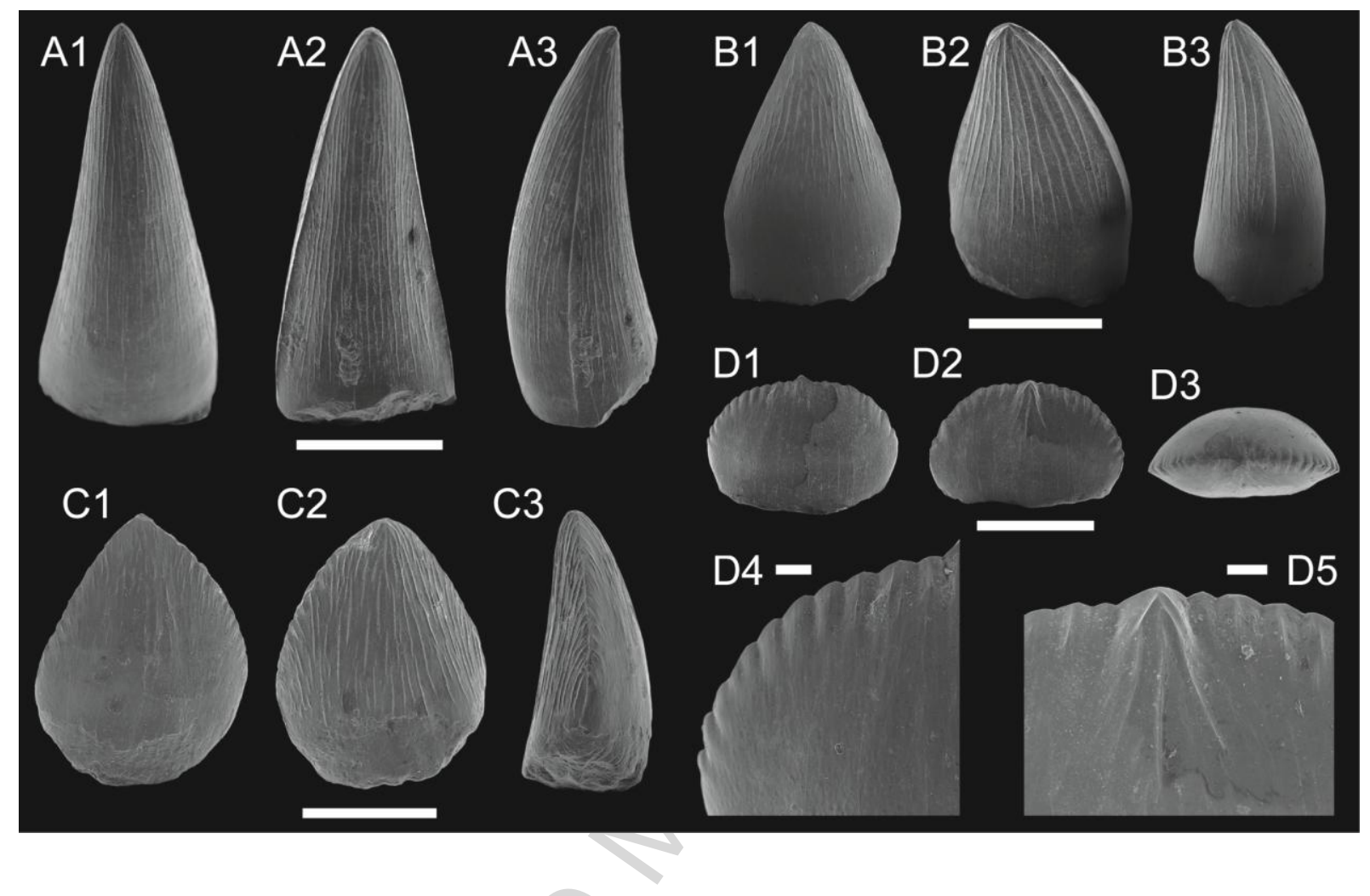

Figure 15 


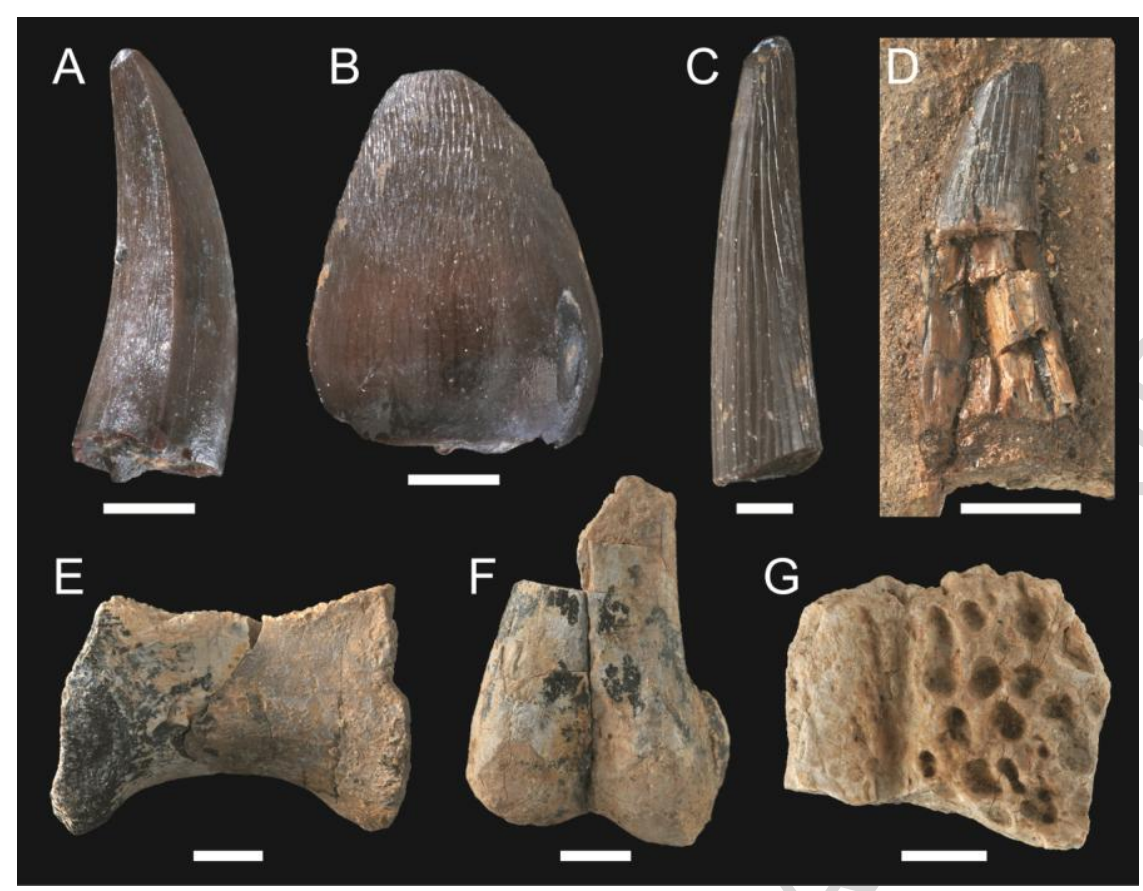

Figure 16 


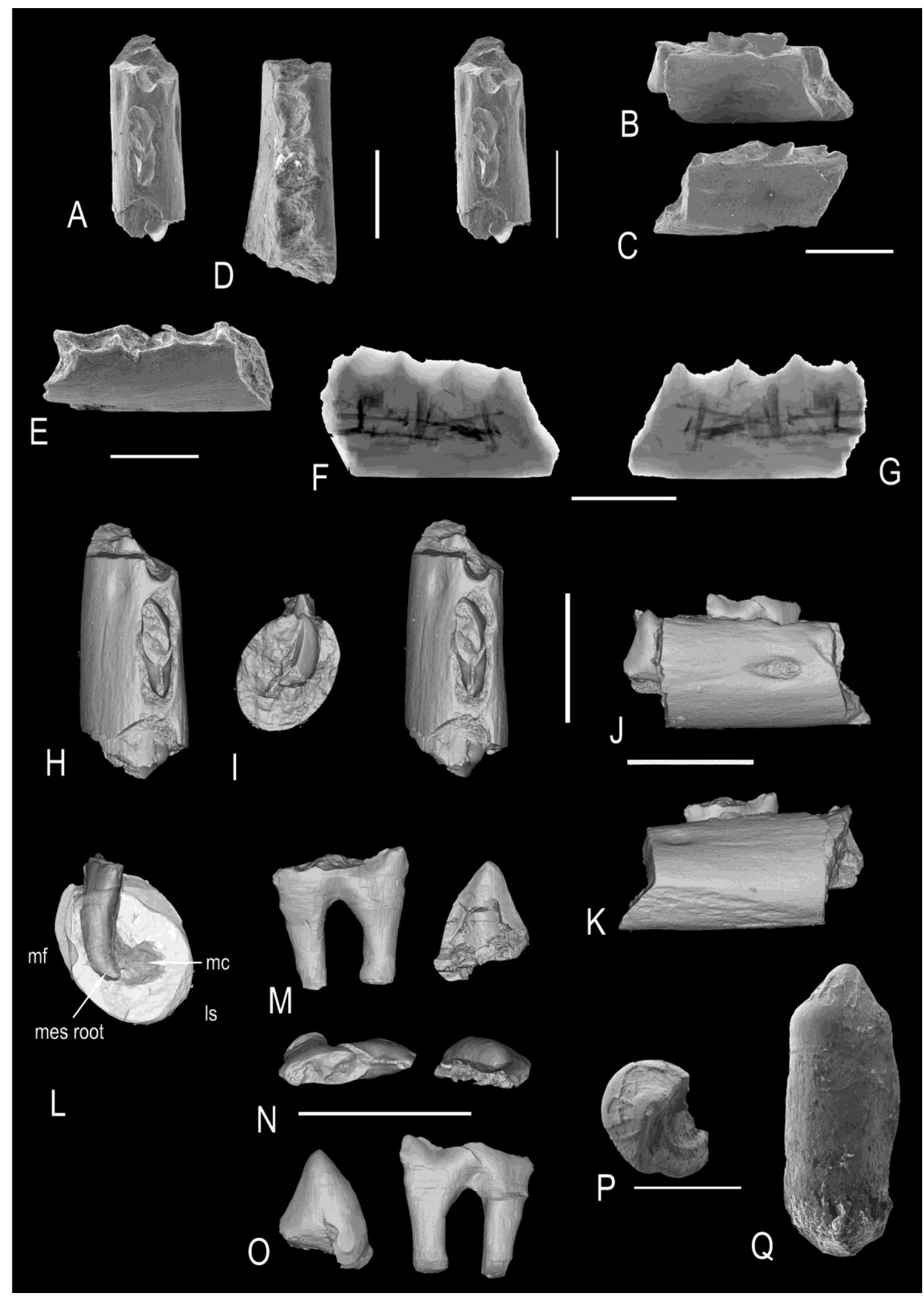

Figure 17 

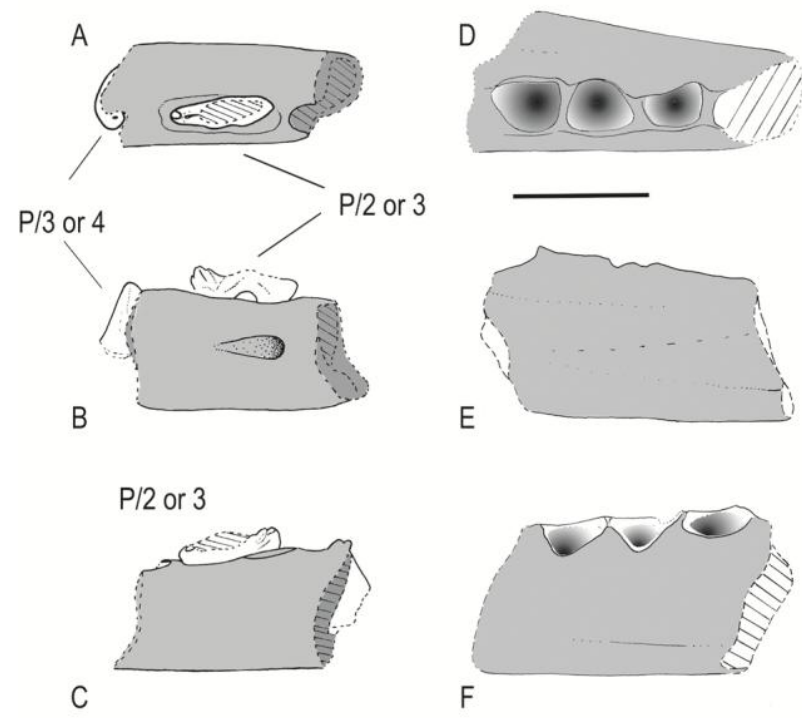

Figure 18 


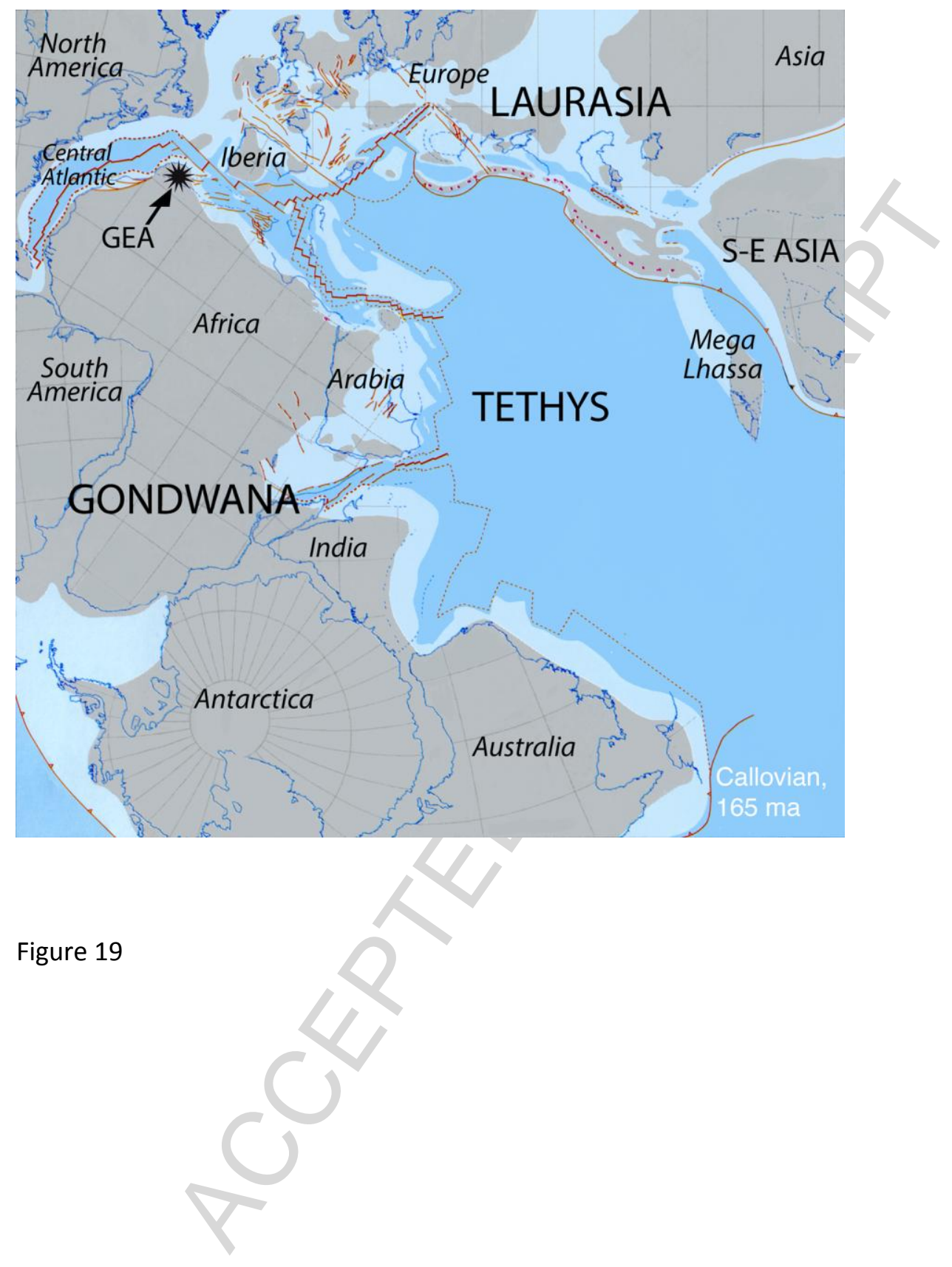



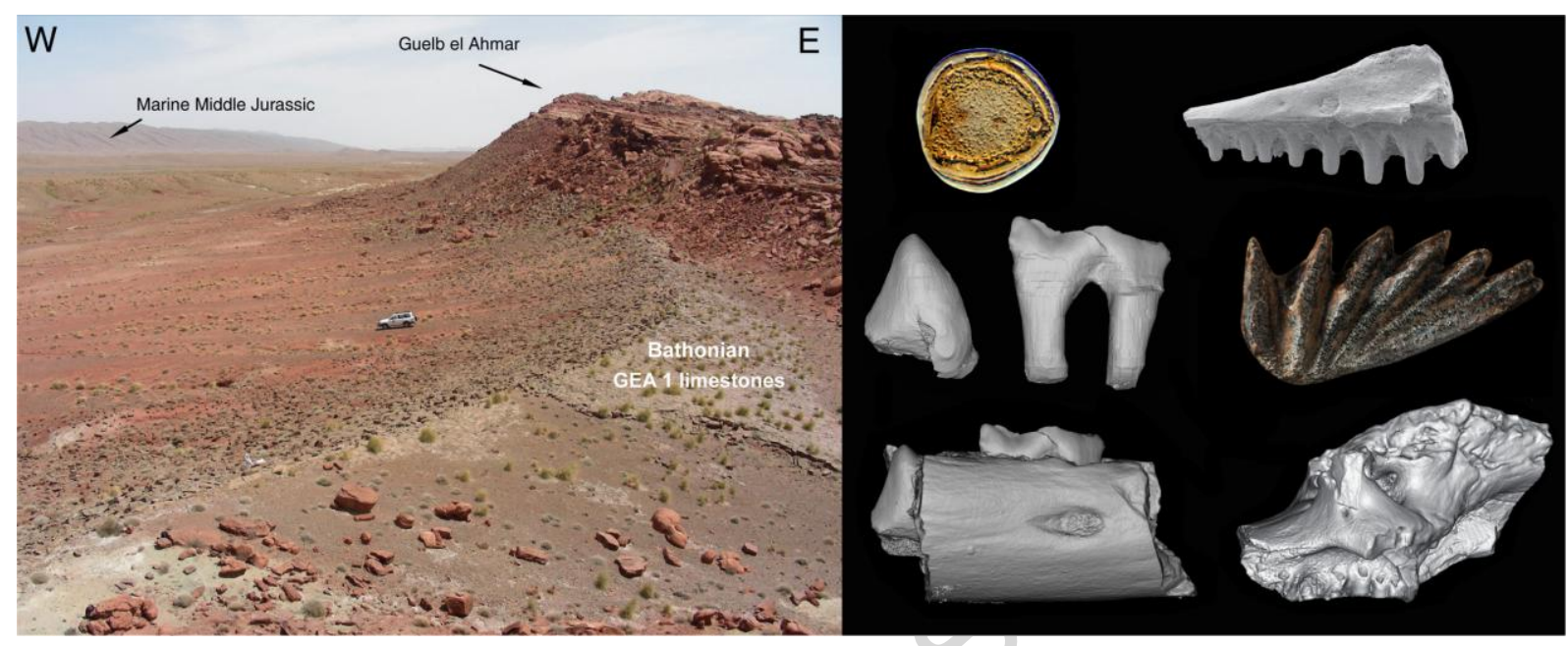

Graphical abstract 